Climate Change Expert Group

Paper No.2017(6)

\title{
Enhancing mitigation and finance reporting
}

Building on current experience to meet the Paris Agreement requirements

Lola Vallejo (OECD), Sara Moarif (IEA) and Aidy Halimanjaya (Universitas Padjadjaran SDGs Center) 


\section{OECD/IEA CLIMATE CHANGE EXPERT GROUP PAPERS}

This series is designed to make available to a wider readership selected papers on climate change issues that have been prepared for the OECD/IEA Climate Change Expert Group (CCXG). The CCXG (formerly called the Annex I Expert Group) is a group of government delegates from OECD and other industrialised countries. The aim of the group is to promote dialogue and enhance understanding on technical issues in the international climate change negotiations. CCXG papers are developed in consultation with experts from a wide range of developed and developing countries, including those participating in the regular Global Forum on the Environment organised by the CCXG. The full papers are generally available only in English.

The opinions expressed in these papers are the sole responsibility of the author(s) and do not necessarily reflect the views of the OECD, the IEA or their member countries, or the endorsement of any approach described herein.

Comments on the series are welcome, and should be sent to:

OECD Environment Directorate, 2 rue André Pascal, 75775 PARIS CEDEX 16, France, or by e-mail to env.contact@oecd.org

\section{OECD/IEA Climate Change Expert Group Papers are published on www.oecd.org/environment/cc/ccxg.htm}

This document and any map included herein are without prejudice to the status of or sovereignty over any territory, to the delimitation of international frontiers and boundaries and to the name of any territory, city or area.

The statistical data for Israel are supplied by and under the responsibility of the relevant Israeli authorities. The use of such data by the OECD is without prejudice to the status of the Golan Heights, East Jerusalem and Israeli settlements in the West Bank under the terms of international law.

This document has been produced with the financial assistance of the European Union.

The views expressed herein can in no way be taken to reflect the official opinion of the European Union.

\section{(c) Copyright OECD/IEA (2017)}

You can copy, download or print OECD content for your own use, and you can include excerpts from OECD publications, databases and multimedia products in your own documents, presentations, blogs, websites and teaching materials, provided that suitable acknowledgement of OECD as source and copyright owner is given.

All requests for commercial use and translation rights should be submitted to rights@oecd.org Applications for permission to reproduce or translate all or part of this material should be addressed to:

Head of Publications Service

OECD, 2 rue André-Pascal, 75775 Paris Cedex 16, France

or

IEA, 9 rue de la Fédération, 75739 Paris Cedex 15, France 


\title{
Foreword
}

This document was prepared by the OECD and IEA Secretariats in response to a request from the Climate Change Expert Group (CCXG) on the United Nations Framework Convention on Climate Change (UNFCCC). The Climate Change Expert Group oversees development of analytical papers for the purpose of providing useful and timely input to the climate change negotiations. These papers may also be useful to national policymakers and other decision-makers. Authors work with the CCXG to develop these papers. However, the papers do not necessarily represent the views of the OECD or the IEA, nor are they intended to prejudge the views of countries participating in the CCXG. Rather, they are Secretariat information papers intended to inform Member countries, as well as the UNFCCC audience.

Members of the CCXG are those countries who are OECD members and/or who are listed in Annex I of the UNFCCC (as amended by the Conference of the Parties in 1997 and 2010). The Annex I Parties or countries referred to in this document are: Australia, Austria, Belarus, Belgium, Bulgaria, Canada, Croatia, Czech Republic, Denmark, the European Community, Estonia, Finland, France, Germany, Greece, Hungary, Iceland, Ireland, Italy, Japan, Latvia, Liechtenstein, Lithuania, Luxembourg, Malta, Monaco, the Netherlands, New Zealand, Norway, Poland, Portugal, Romania, the Russian Federation, Slovak Republic, Slovenia, Spain, Sweden, Switzerland, Turkey, Ukraine, the United Kingdom of Great Britain and Northern Ireland, and the United States of America. Korea, Mexico, Chile and Israel are also members of the CCXG. Where this document refers to "countries" or "governments", it is also intended to include "regional economic organisations”, if appropriate.

\section{Acknowledgements}

The authors would like to thank Carly Soo for her background research and input in the document and Justine Garrett for incorporating comments from Global Forum delegates and finalising paper revisions. The authors would like to acknowledge helpful comments from OECD and IEA colleagues Jane Ellis, Simon Buckle, Christina Hood, Raphael Jachnik, Lauren McNicoll, Mariana Mirabile, Andrew Prag, Guillaume Simon and Manasvini Vaidyula. The authors would also like to thank delegates to the September 2017 CCXG Global Forum on the Environment and Climate Change for their comments on earlier versions of this paper, in particular delegates and experts from the following countries and organisations: Australia, Brazil, Chile, Moldova, Mexico, Indonesia, Japan, Republic of Korea, Singapore, CITEPA, ICAT, ODI, UNDP and UNFCCC Secretariat.

The Secretariat would like to thank Australia (Department of Foreign Affairs and Trade), Belgium (Federal Public Service Health, Food Chain Safety and Environment), the European Commission, Finland (Ministry of the Environment), France (Ministry of Foreign Affairs and International Development), Germany (Ministry for Environment, Nature, Conservation, Building and Nuclear Safety), Japan (Ministry of the Environment), Netherlands (Ministry of Infrastructure and Environment), New Zealand (Ministry for the Environment), Norway (Ministry of Climate and Environment), Republic of Korea (Korea Energy Economics Institute), Sweden (Environmental Protection Agency) and Switzerland (Federal Office for the Environment), for their direct funding of the CCXG in 2017, and the OECD and IEA for their in-kind support.

\author{
Jane Ellis \\ OECD Environment Directorate \\ 2, rue André-Pascal \\ 75775 Paris Cedex 16 \\ France \\ Email: jane.ellis@oecd.org
}

Questions and comments should be sent to:

All OECD and IEA information papers for the Climate Change Expert Group on the UNFCCC can be downloaded from: www.oecd.org/environment/cc/ccxg.htm 


\section{Abstract \\ Enhancing mitigation and finance reporting}

Building on current experience to meet the Paris Agreement requirements

The future enhanced transparency framework outlined in the Paris Agreement and its accompanying Decision is to build on, enhance and eventually supersede the existing measurement, reporting and verification (MRV) system established under the Cancún Agreements. This paper explores the issues of "building on" and "enhancing" as they relate to the biennial reporting of information on mitigation and finance, by drawing lessons from the existing MRV system and examining the Paris Agreement's provisions. It examines four areas: greenhouse gas (GHG) inventories, reporting on progress with the mitigation component of nationally determined contributions (NDCs), finance provided and mobilised, and financial support received and needed. The paper also highlights the challenges met by Parties while reporting information for these areas to date, and provides suggestions on how forthcoming modalities, procedures and guidelines (MPGs) might reduce these difficulties.

JEL Classification: F53, O44, Q54, Q56, Q58

Keywords: transparency, mitigation, climate finance, climate change, UNFCCC

\section{Résumé}

Amélioration de la notification d'informations sur l'atténuation et le financement

Mettre à profit l'expérience actuelle pour respecter les exigences de l’Accord de Paris

Le futur cadre de transparence renforcé décrit dans l'Accord de Paris et la Décision qui l'accompagne s'appuiera sur le système de mesure, de notification et de vérification (MNV) existant établi dans le cadre des accords de Cancún, renforcera ce système et le remplacera à terme. Le présent document analyse les notions de «s'appuyer sur » et « renforcer » dans le contexte de la notification bisannuelle d'informations sur l'atténuation et le financement, en tirant les enseignements du système MNV existant et en examinant les dispositions de l'Accord de Paris. Quatre aspects sont étudiés : les inventaires des gaz à effet de serre (GES), la notification des progrès sur le volet atténuation des contributions déterminées au niveau national (CDN), le financements fournis et mobilisés, et l'appui financier reçu et nécessaire. Ce document met aussi en lumière les difficultés rencontrées jusqu'à présent par les Parties pour notifier des informations sur ces aspects, et présente des suggestions pour réduire ces difficultés dans le cadre des futures modalités, procédures et lignes directrices.

Classification JEL : F53, O44, Q54, Q56, Q58

Mots-clés : transparence, atténuation, financement de l'action climatique, changement climatique, CCNUCC 


\section{Table of contents}

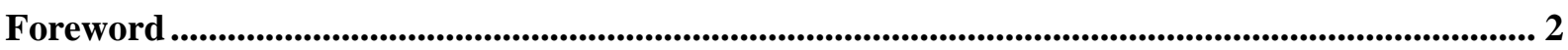

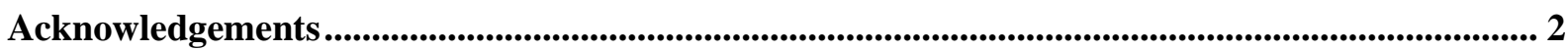

Abstract ................................................................................................................................................. 3

Résumé ............................................................................................................................................. 3

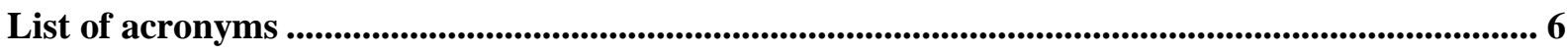

Executive summary ......................................................................................................................................... 8

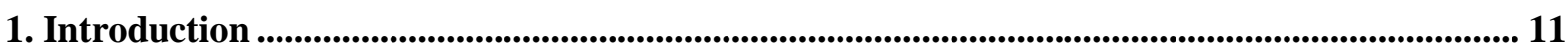

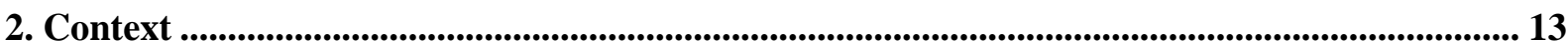

3. Enhancement of mitigation reporting..................................................................................................... 17

3.1. Mitigation reporting within the Paris Agreement ...................................................................... 17

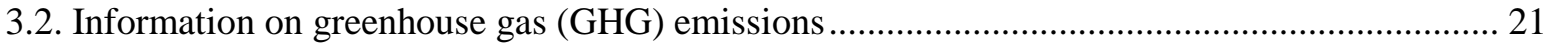

3.3. Information on progress with implementation and achievement of NDCs................................ 27

4. Enhancement of finance reporting - finance provided and mobilised ............................................ 35

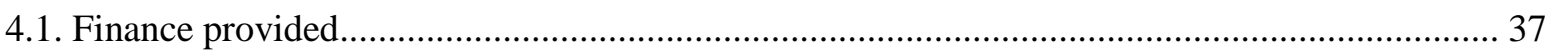

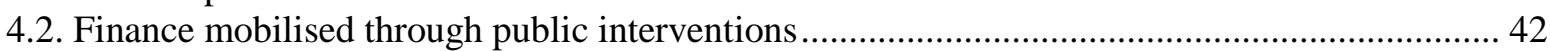

4.3. Proposing an enhanced finance reporting system for developed countries and "other" Parties . 44

5. Enhancement of finance reporting - financial support received and needed ............................... 51

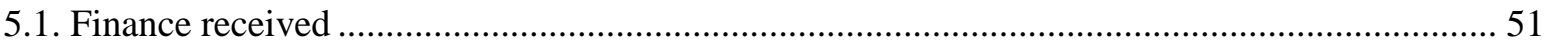

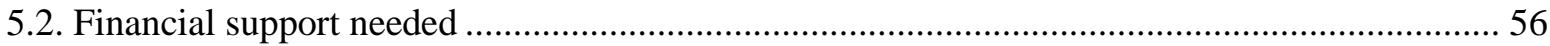

5.3. Proposing an enhanced finance reporting system for developing countries .............................. 59

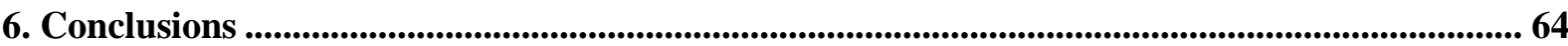

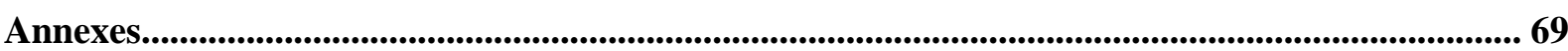

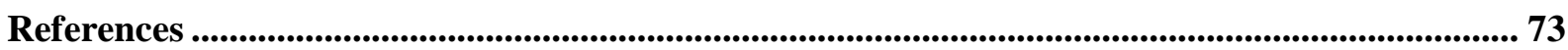




\section{Tables}

Table 1. Comparison of concepts: Paris Agreement transparency framework and MRV arrangements under the Cancún Agreements.

Table 2. Overview of reporting provisions of the enhanced transparency framework under the Paris Agreement and the MRV arrangements under the Cancún Agreements........................................ 16

Table 3. Current reporting requirements for inventories..................................................................... 21

Table 4. Comments and suggestions on APA informal note outline: GHG inventories ........................ 26

Table 5. Comments and suggestions on APA informal note outline: Progress with NDCs.................. 33

Table 6. Diversity of approaches and key issues with reporting on bilateral finance in the second

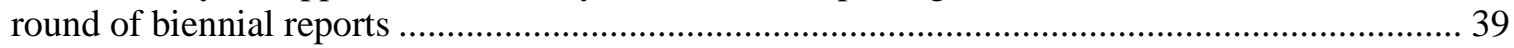

Table 7. Use of Rio Markers in the reporting of bilateral finance in biennial reports.......................... 41

Table 8. Comments and suggestions on APA informal note outline: finance provided and mobilised 46

Table 9. Potential CTF table elements to account for private finance mobilised by public interventions 49

Table 10. Information on finance received in non-Annex I Parties' BURs

Table 11. Examples of purpose-built climate change monitoring systems for finance received in nonAnnex I Parties

Table 12. Information on financial support needed in non-Annex I Parties' BURs ............................. 57

Table 13. Examples of non-Annex I country reporting arrangements for climate finance needs .......... 59

Table 14. Gradual approach to enhancing climate finance monitoring and reporting systems by

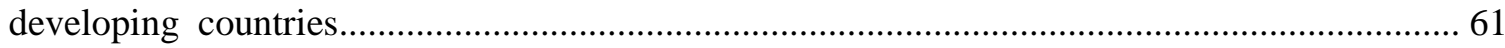

Table 15. Current content of inventory submission guidelines (Decision 24/CP.19) ........................... 69

Table 16. Information to track progress with NDC: outline in APA non-paper compared with BUR

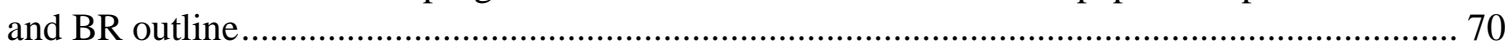

Table 17. Examples of national monitoring arrangements adapted to include climate finance received71

\section{Figures}

Figure 1. Links between reporting provisions on mitigation and other key elements of the Paris Agreement

Figure 2. Links between financial support reporting provisions, relevant work programmes and other key elements of the Paris Agreement 36

Figure 3. Potential reporting Parties on finance provided and mobilised (developed country Parties and other Parties providing support) 48

\section{Boxes}

Box 1. Robust monitoring system of climate finance supports efforts to track private climate finance:

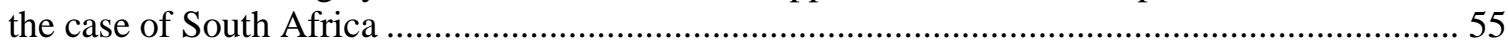

Box 2. Potential elements for developing country reporting of climate finance received..................... 62

Box 3. Potential elements for developing-country reporting of climate finance needed (project and programme focus). 


\section{List of acronyms}

\begin{tabular}{|c|c|}
\hline ADP & $\begin{array}{l}\text { Ad hoc Working Group on the Durban Platform for Enhanced } \\
\text { Action }\end{array}$ \\
\hline APA & Ad Hoc Working Group on the Paris Agreement \\
\hline AILAC & Association of Latin America and the Caribbean \\
\hline AOSIS & Alliance of Small Island States \\
\hline BAU & Business-as-usual \\
\hline BR & Biennial Report \\
\hline BR-DI & Biennial Report Data Interface \\
\hline BUR & Biennial Update Report \\
\hline CCXG & Climate Change Expert Group \\
\hline CER & Certified Emission Reduction \\
\hline CDM & Clean Development Mechanism \\
\hline CGE & $\begin{array}{l}\text { Consultative Group of Experts on National Communications } \\
\text { from non-Annex I Parties }\end{array}$ \\
\hline CMA & $\begin{array}{l}\text { Conference of the Parties serving as the Meeting of the Parties } \\
\text { to the Paris Agreement }\end{array}$ \\
\hline CMP & $\begin{array}{l}\text { Conference of the Parties serving as the Meeting of the Parties } \\
\text { to the Kyoto Protocol }\end{array}$ \\
\hline COP & Conference of the Parties to the UNFCCC \\
\hline CPEIR & Climate Public Expenditure and Institutional Reviews \\
\hline CRF & Common Reporting Format \\
\hline CRS & OECD-DAC’s Creditor Reporting System \\
\hline CTF & Common Tabular Format \\
\hline CTU & Clarity, Transparency and Understanding \\
\hline DAC & OECD Development Assistance Committee \\
\hline DEA & Department of Environmental Affairs [South Africa] \\
\hline EU & European Union \\
\hline EIT & Economies in Transition \\
\hline GCF & Green Climate Fund \\
\hline GDP & Gross Domestic Product \\
\hline GEF & Global Environment Facility \\
\hline GHG & Greenhouse Gas \\
\hline GNI & Gross National Income \\
\hline GST & Global Stocktake \\
\hline GTP & Global Temperature Potential \\
\hline GWP & Global Warming Potential \\
\hline IAR & International Assessment and Review \\
\hline IATI & International Aid Transparency Initiative \\
\hline IEA & International Energy Agency \\
\hline INDC & Intended Nationally Determined Contributions \\
\hline IPCC & Intergovernmental Panel on Climate Change \\
\hline IPCC GL & Intergovernmental Panel on Climate Change Guidelines \\
\hline ITMO & Internationally Transferred Mitigation Outcome \\
\hline LDC & Least Developed Country \\
\hline
\end{tabular}




\begin{tabular}{|c|c|}
\hline LMDCs & Like-Minded Developing Countries \\
\hline LULUCF & Land use, Land Use Change, and Forestry \\
\hline MDB & Multilateral Development Bank \\
\hline MOI & Means of Implementation \\
\hline MPG & Modalities, Procedures and Guidelines \\
\hline MRV & Measurable, Reportable and Verification \\
\hline NAIIS & Non-Annex I Inventory Software \\
\hline NAMA & Nationally Appropriate Mitigation Actions (NAMAs) \\
\hline NAPA & National Adaptation Programmes of Action \\
\hline NAP & National Adaptation Plans \\
\hline NC & National Communications \\
\hline NDC & Nationally Determined Contribution \\
\hline NIR & National Inventory Report \\
\hline NGO & Non-Governmental Organisation \\
\hline ODA & Official Development Assistance \\
\hline OECD & Organisation for Economic Co-operation and Development \\
\hline OOF & Other Official Flows \\
\hline QWIDS & $\begin{array}{l}\text { OECD DAC Query Wizard for International Development } \\
\text { Statistics }\end{array}$ \\
\hline REDD+ & $\begin{array}{l}\text { Reducing emissions from Deforestation and forest Degradation } \\
\text { in developing countries, and the role of conservation, } \\
\text { sustainable management of forests, and enhancement of forest } \\
\text { carbon stocks }\end{array}$ \\
\hline SBI & Subsidiary Body for Implementation \\
\hline SBSTA & Subsidiary Body for Scientific and Technological Advice \\
\hline SCF & Standing Committee on Finance \\
\hline SDG & Sustainable Development Goals \\
\hline SIDS & Small Island Developing States \\
\hline TACCC & $\begin{array}{l}\text { Transparency, Accuracy, Completeness, Consistency, } \\
\text { Comparability }\end{array}$ \\
\hline TOSSD & Total Official Support for Sustainable Development \\
\hline UN & United Nations \\
\hline UNDP & United Nations Development Programme \\
\hline UNEP & United Nations Environment Programme \\
\hline UNFCCC & United Nations Framework Convention on Climate Change \\
\hline USD & United States Dollar \\
\hline
\end{tabular}




\section{Executive summary}

1. The future enhanced transparency framework outlined in the Paris Agreement and Decision 1/CP.21 represents an evolution from the existing transparency system, and includes elements of both continuity and innovation. The enhanced transparency framework is to "build on and enhance" (Art. 13.3) and "eventually supersede" (Decision 1/CP.21 Paragraph 98) the existing measurement, reporting and verification (MRV) system established under the Cancún Agreements, in particular the biennial reports (BRs) and biennial update reports (BURs) established for Annex I and nonAnnex I Parties respectively (Decision 2/CP.17).

2. This paper explores the issues of "building on" and "enhancing" as they relate to the biennial reporting of information on mitigation and finance, ${ }^{1}$ by drawing lessons from the existing MRV system and examining the Paris Agreement's provisions. The paper examines four areas: greenhouse gas (GHG) inventories, reporting on progress with nationally determined contributions (NDCs) under Article 4, finance provided and mobilised, and financial support received and needed. The paper also highlights the challenges met to date by Parties while reporting information for these areas, and underlines how forthcoming modalities, procedures and guidelines (MPGs) might reduce these difficulties. While each subject area has its particularities and specific challenges, the paper highlights a few broadly-applicable lessons:

- Improving reporting by Parties requires time and resources, since this is largely a function of domestic monitoring and evaluation systems that can take time to establish or modify. Developing systems that can improve over time and that deliver multiple benefits domestically (e.g. for strategic planning, and implementation) is important given resource constraints in many countries.

- Having common guidelines does not mean Parties would all need to report the same content. There is scope for flexibility while at the same time encouraging countries to report to a certain level of detail and completeness, and to improve reporting over time.

- Guidelines, even if they are not designed in a "one size fits all” way, need to be clear and specific to avoid inconsistent interpretation by Parties. Including suggestions, explanations, and examples within guidelines also facilitates reporting. This is especially true for areas where Parties have limited experience with reporting, such as climate finance received.

- Some information can only be reported in a comparable manner if there are consistent ways for the information to be identified or derived, such as agreement on how to prepare GHG inventories or definitions for different categories of type of finance to be reported.

- Developing common formats and online tools or building upon existing ones can facilitate reporting of GHG inventories and financial information, which are both data-heavy and can draw on calculation tools and databases developed

\footnotetext{
${ }^{1}$ Although not covered in this paper, adaptation, technology and capacity-building also require further work to develop common modalities, procedures and guidelines for reporting.
} 
outside the United Nations Framework Convention on Climate Change (UNFCCC).

3. The Paris Agreement introduces several changes from the existing MRV system, notably by not distinguishing between explicit groups of Parties regarding MPGs as they apply to mitigation. The enhanced transparency framework occurs in the context of different forms of NDCs put forward by all Parties, and will need to accommodate this diversity. The Paris Agreement also acknowledges that those countries with robust reporting today must continue to improve, and that some developing country Parties will need additional flexibility based on their capacities.

4. Reporting arrangements for finance will include three sets of countries under the Paris Agreement: “developed", “developing" and "other countries". The distinction is based on the requirement that developed country Parties provide and mobilise finance to assist developing country Parties. The "other countries" category invites countries that are not "developed", but who may also provide and mobilise resources for developing countries, to report this information voluntarily. Countries may choose to apply reporting provisions in a way that matches their capacities applying the most detailed guidelines in areas where they have sufficient capacity, and reporting in a less complete way in other areas while aspiring to improve reporting over time.

5. For both mitigation and finance reporting, the paper benefits from Parties' initial thinking about headings and sub-headings related to reporting within the Ad Hoc Working Group on the Paris Agreement (APA) negotiations. This paper suggests several provisions for reporting on mitigation. These include the need for more detail and options than in existing guidelines to accommodate Parties' different types of NDCs, the self-identification of Parties' need for flexibility based on current experience, and the upfront inclusion of the principle of "no backsliding" on the quality and frequency of current levels of reporting. The paper also suggests explicitly including Parties' plans to improve reporting over time within their biennial progress reports and linking it to their reporting of capacity needs, as well as including information relevant for the purpose of a collective assessment, even though it may not be immediately relevant to communicating progress.

6. For climate finance provided and mobilised, the paper suggests areas where reporting requirements could potentially be revised (e.g. on finance mobilised through public channels, should Parties wish to adopt common reporting elements in this area). It points to the potential benefits of introducing voluntary, disaggregated reporting from multilateral public finance providers on finance provided and mobilised in terms of increasing consistency. The paper also suggests mechanisms to encourage improvement in reporting over time by other countries providing and mobilising resources, and the creation of an online interface enabling data export and personalised searches for finance provided and mobilised.

7. Given limited current reporting by non-Annex I countries on finance received and needed, and the Paris Agreement's emphasis on facilitating improvement and implementation, the paper proposes a gradual approach for how developing countries might enhance reporting in this area over time. Developing countries could potentially build on existing public financial and monitoring systems and report basic data on climate finance received and needed as a starting point. They could also focus on the development of a publicly-accessible pipeline of mitigation and adaptation projects and programmes, as a sub-set of information on climate finance needs. 
8. The following specific provisions of the Paris Agreement have far reaching implications that affect reporting across all four areas:

- The purpose of informing the global stocktake starting in 2023, with implications for more complete and consistent information from a wider set of Parties, including more standard reporting tools and formats and making information reported more easily available and accessible;

- The emphasis on facilitating improvement and implementation, with implications for guidance that is more detailed, specific and helpful compared with what is in place today;

- Biennial reporting from all Parties, with flexibility for developing country Parties that need it in light of their capacities. Such a frequency of reporting would imply significant increases in various types of domestic monitoring, reporting and assessment capacities and associated support in some Parties.

9. Developing reporting guidelines will form just one part of the MPGs that Parties are to elaborate under the Paris Agreement. Parties will need to further consider how the information reported is then being used, and how the technical expert review and multilateral consideration of progress can facilitate further improvements not only in reporting, but also in implementation. Clearer and more precise guidance can also facilitate reporting, such as on what information needs to be collected, how to start collecting certain types of information and which calculation methods to use. Parties may therefore want to co-ordinate the development of MPGs with the on-going work on accounting for NDCs and accounting for financial resources provided and mobilised, respectively under the APA and the Subsidiary Body for Scientific and Technological Advice. Should these three work programmes work in synergy, the Paris Agreement could stimulate a virtuous cycle in increasing ambition, improving data availability and enhancing transparency. NDCs could lead to more ambitious domestic climate policies, which may then elicit the need for robust data on both mitigation and finance; the various transparency-related initiatives providing support to countries ought to further enable these domestic processes. 


\section{Introduction}

10. The enhanced transparency framework is a key element of the Paris Agreement. The framework applies to actions taken by Parties on mitigation and adaptation to climate change, and support provided and received by Parties, encompassing finance, technology and capacity-building. It includes provisions for the reporting of information, as well as for review of this information and a consideration of progress with respect to information on mitigation and support provided. The framework applies to all Parties, with flexibility for those developing country Parties that need it in the light of their capacities. The enhanced transparency framework is to "build on and enhance" (Art. 13.3) and "eventually supersede" (Decision 1/CP.21 Paragraph 98) the existing measurement, reporting and verification (MRV) system established under the Cancún Agreements, in particular the biennial reports (BRs) and biennial update reports (BURs) established for Annex I and non-Annex I Parties respectively (Decision 2/CP.17). ${ }^{2}$

11. The purpose of the enhanced transparency framework (Art. 13.5 and 13.6) is to provide a clear understanding of climate change action, provide clarity on support provided and received by relevant individual Parties, and to inform the global stocktake of collective progress towards the long-term goals of the Agreement. The enhanced transparency framework is also to "build mutual trust and confidence" and to promote effective implementation" (Art. 13.1). Reporting information can build trust, providing reassurance that countries are planning and implementing domestic climate policies and delivering on their climate finance commitments. This can facilitate more ambitious climate action over time (Briner and Moarif, 2016 ${ }_{[1]}$; Ellis and Moarif, 2016 ${ }_{[2]}$ ), for example clarifying issues such as the current gap between some Parties' estimates of finance provided and received (see section 5.1). Reporting can also promote implementation, given its domestic benefits. It can raise the political profile of climate change and better integrate it into policy planning processes, increase the accountability of donor country governments to their taxpayers, and help assess whether finance is being channelled towards priority sectors and activities (Ellis and Moarif, 2016 $\left.{ }_{[2]}\right)$. The information collected for reporting also enables planning and implementing domestic measures, and the process of doing so can support improvements in domestic monitoring and management systems (Briner and Moarif, $\left.2016_{[1]}\right)$. Tracking and reporting on progress has resource implications for all countries, which is why the Paris Agreement transparency framework is to "avoid placing an undue burden on Parties" (Art. 13.3) and avoid duplication.

12. This paper focuses on some aspects of the enhanced transparency framework, building on previous work from the Climate Change Expert Group (Briner and Moarif, 2016 $[1]$; Briner and Moarif, 2016 $[3]$; Ellis and Moarif, 2016 $[2]$; Ellis and Moarif, $\left.2015_{[4]}\right)$. It focuses on mitigation- and finance-related information to be reported biennially for most Parties under the Paris Agreement framework (Para. 90 and 92e,

\footnotetext{
${ }^{2}$ Paragraph 98 of Decision 1/CP.21 refers to paragraphs in Decision 1/CP.16 which refer not only to biennial reporting, but also enhanced reporting within National Communications and Annex I GHG inventory reports. However, this paper will focus on biennial reporting arrangements and GHG inventory submissions.
} 
Decision 1/CP.21), and which will supersede current reporting done biennially (Para. 98, Decision 1/CP.21). This covers national inventory reports, information necessary to track progress with nationally determined contributions under Article 4, financial support provided, needed and received (Articles 13.7, 13.9 and 13.10). Though some of this information is currently also reported in national communications (NCs), in examining current experience this paper will focus on biennial reporting established by the Cancún Agreements and operationalised via biennial reporting guidelines in Decision 2/CP.17. This paper does not examine review or consideration of progress.

13. This paper examines how reporting of information under the Paris Agreement can a) build on current experience by drawing out lessons from current practice; and b) be enhanced, drawing from not only from current experience under and outside the United Nations Framework Convention on Climate Change (UNFCCC), but also from the provisions and implications of the Paris Agreement. In that context, enhancement of reporting can take the form of:

- filling current gaps in reporting, focusing on the information to be reported biennially (e.g. greenhouse gas emissions and finance provided, vs. information that changes less frequently, such as national circumstances);

- fulfilling new information requirements, set by the Paris Agreement;

- reducing the resources required to report information, for instance through streamlining and improving consistency between the information being requested in different parts of guidelines, and between different sets of guidelines (e.g. accounting and reporting).

14. The paper starts by providing context for transparency framework discussions and negotiations under the Paris Agreement (section 2), and then discusses mitigation (section 3), finance provided and mobilised (section 4), and financial support received and needed (section 5). In each section, the paper briefly summarises current reporting arrangements and key lessons from current experience, and then explores implications of the Paris Agreement and options for reporting. The conclusions summarise some key lessons from current experience, and provide recommendations for the development of modalities, procedures and guidelines, as well as options for future work (section 6). 


\section{Context}

15. The future transparency framework outlined in the Paris Agreement and Decision 1/CP.21 represents an evolution from the existing transparency system. Several features of the existing transparency system under the UNFCCC will remain in place, such as reporting of greenhouse gas (GHG) inventories, and biennial tracking of progress towards mitigation objectives and support-related commitments.

16. There are also interesting similarities and differences between the concepts associated with reporting arrangements under the Cancún agreements and those of the upcoming enhanced transparency framework (Table 1). In both cases, there are references to the concepts of flexibility, progression or enhancement of transparency over time, avoiding burden, and enabling confidence in the information reported. In some cases similar language is used, and in others the language used may have different meanings or applicability between the two frameworks. For example, comparability of information is a concept used to build trust and confidence in information reported; previously referenced only for information from Annex I Parties, the term is broadly applied to the entire Paris Agreement transparency framework (Decision 1/CP.21 Paragraph 92c; Art. 4.13).

17. A closer look at the provisions contained in the Paris Agreement and its accompanying decision highlight several differences with the provisions and those of the existing reporting system (Table 2). For mitigation, there is no difference made between groups of Parties regarding modalities, procedures and guidelines (MPGs) of the transparency framework; these are meant to be common and apply to all Parties. However, there are exemptions for least developed countries (LDCs) and small island developing states (SIDS), flexibility for developing countries that need it on the basis of their capacities (Briner and Moarif, 2016 ${ }_{[3]}$ ), and a specific requirement for Parties not to report less frequently or robustly than they do at present (Decision 1/CP.21 Paragraph 92e). This represents a major shift from the simpler, binary distinctions in the UNFCCC and Cancún Agreements between the obligations for Annex I and nonAnnex I Parties.

18. This binary distinction is also present in the existing reporting system for finance, where Annex II Parties have specific reporting obligations. Under the Paris Agreement, reporting arrangements for finance refer to three new categories of countries: "developed”, “developing”, and "other countries” that provide and mobilise resources. In the absence of a definition of which category countries belong to, there is more flexibility for countries to interpret these terms and decide which reporting provisions best apply to them.

19. The provisions for flexibility are more nuanced in the Paris Agreement, with the term applying more specifically to those developing country Parties that need it in the light of their capacities (Art. 13.2), rather than all non-Annex I Parties. Countries may choose to apply reporting provisions differently, in a way that matches their capacities - applying the most ambitious guidelines in areas where they have sufficient capacity, reporting in a less complete way in other areas, and enhancing the completeness and transparency of their reporting over time. 
Table 1. Comparison of concepts: Paris Agreement transparency framework and MRV arrangements under the Cancún Agreements

\begin{tabular}{|c|c|c|}
\hline & $\begin{array}{l}\text { Enhanced transparency framework under Paris } \\
\text { Agreement }\end{array}$ & MRV arrangements under Cancún Agreements \\
\hline Flexibility & $\begin{array}{l}\text { - "Shall provide flexibility in the implementation [...] to those } \\
\text { developing country Parties that need it in the light of their } \\
\text { capacities" (Art. 13.2) } \\
\text { - In accordance with Art. } 13.2 \text { developing country Parties } \\
\text { shall be provided flexibility in the implementation of the } \\
\text { provisions of Article } 13 \text { (Paragraph } 89 \text { ) } \\
\text {-LDCs and SIDS may submit information referred to in Article } \\
13 \text { at their discretion (Paragraph 90) }\end{array}$ & $\begin{array}{l}\text { - Additional flexibility [in non-Annex I reporting] to be } \\
\text { given to the least developed country Parties and small } \\
\text { island developing States" (Decision 1/CP.16 } \\
\text { Paragraph } 60 \text { ) } \\
\text { - [BUR guidelines] to respect the diversity of mitigation } \\
\text { actions and provide flexibility for non-Annex I Parties to } \\
\text { report information (Decision 2/CP.17, para. 40) }\end{array}$ \\
\hline Progression & $\begin{array}{l}\text { - "Shall build on and enhance the transparency } \\
\text { arrangements" under the UNFCCC (Art. 13.3), highlighting } \\
\text { "the importance of facilitating improved reporting and } \\
\text { transparency over time" and the "need to ensure that Parties } \\
\text { maintain at least the frequency and quality of reporting in } \\
\text { accordance with their respective obligations" under the } \\
\text { Convention (Decision 1/CP.21 Paragraph 92) }\end{array}$ & $\begin{array}{l}\text { - "Enhance the guidelines for the reporting of } \\
\text { information in national communications by Parties } \\
\text { included in Annex I" (Decision } 1 / C P .16 \text { Paragraph } 41 \text { ) } \\
\text { and "enhance reporting in national communications, } \\
\text { [...] from Parties not included in Annex I to the } \\
\text { Convention on mitigation actions and their effects, and } \\
\text { support received" (Decision } 1 / C P .16 \text { Paragraph } 60) .{ }^{1} \\
\text { - BUR guidelines "to enable enhanced reporting by } \\
\text { non-Annex I Parties on mitigation actions and their } \\
\text { effects, needs and support received [...]"(Decision } \\
2 / C P .17, \text { Annex III) }\end{array}$ \\
\hline Efficiency & $\begin{array}{l}\text { - Need for the APA to "avoid duplication as well as undue } \\
\text { burden on Parties and the secretariat" in developing the } \\
\text { recommendations for the modalities, procedures and } \\
\text { guidelines for the transparency framework (Decision 1/CP. } 21 \\
\text { Paragraph 92) }\end{array}$ & $\begin{array}{l}\text { "The content and frequency of national } \\
\text { communications from Parties not included in Annex I } \\
\text { to the Convention will not be more onerous than that } \\
\text { for Parties included in Annex I to the Convention" } \\
\text { (Decision 1/CP.16 Paragraph 60) }\end{array}$ \\
\hline $\begin{array}{l}\text { Confidence in the } \\
\text { information reported } \\
\text { (i.e. transparent, } \\
\text { accurate, complete, } \\
\text { consistent, } \\
\text { comparable) }\end{array}$ & $\begin{array}{l}\text { - Need to "promote transparency, accuracy, completeness, } \\
\text { consistency and comparability" (Decision 1/CP.21 Paragraph } \\
92 \text { ) } \\
\text { - [Capacity-building under the Paris Agreement should } \\
\text { facilitate] "the transparent, timely and accurate } \\
\text { communication of information"(Art.11.1) }\end{array}$ & $\begin{array}{l}\text { - Ensure that "information provided [by Annex I Parties] } \\
\text { is complete, comparable, transparent and accurate" } \\
\text { (Decision 1/CP.16 Paragraph 41). } \\
\text { - "Encourage the presentation of information [by non- } \\
\text { Annex I Parties] in a consistent, transparent, complete, } \\
\text { accurate and timely manner, taking into account } \\
\text { specific national and domestic circumstances" } \\
\text { (Decision 2/CP.17, Annex III) }\end{array}$ \\
\hline
\end{tabular}

Note: ${ }^{1}$ Reference to national communications here is relevant in so far as both BR and BUR guidelines reference national communication guidelines, especially in relation to reporting GHG emissions.

Source: Decision 1/CP.16; Decision 2/CP.17; Decision 1/CP.21.

20. The enhanced transparency framework will rest on common MPGs (Art. 13.13), which should reflect this nuanced flexibility (Art. 13.2, Decision 1/CP.21 Paragraph 89). The development of MPGs is to draw upon experience from existing transparency arrangements, to build on and enhance these arrangements, but also to eventually supersede the current measurement, reporting and verification system (Decision 1/CP.21 Paragraph 98). While the Cancún reporting arrangements continued to refer to previous reporting guidelines for national communications (NCs), the Paris Agreement text suggests MPGs will be standalone documents that can refer to new guidance documents being prepared as part of the enhanced transparency framework (e.g. accounting guidance) rather than previous guidance.

21. The MPGs for the enhanced transparency framework for action and support are negotiated under the Ad Hoc Working Group on the Paris Agreement (APA). The development of these common MPGs is linked to several provisions in the Paris Agreement, which are negotiated under different tracks as part of the APA and the 
Subsidiary Body for Scientific and Technological Advice (SBSTA). Interlinkages relevant to reporting of mitigation and finance are discussed in more detail in the specific sections that follow (see Figure 1 and Figure 2).

22. Reporting of information is also linked with two other Agreement provisions, namely the review of reported information, and the provision of support to enable and facilitate reporting by developing countries (see also (Dagnet et al., 2017 ${ }_{[5]}$ ) for a discussion of links). The experience of having reports reviewed is also important for building capacity and improving the quality of reporting, in part because this allows domestic resources to be channelled in support of improvements (Briner and Moarif, 2017). Under current practice, information for which reporting is mandatory is more heavily scrutinised during any review process, and in turn benefits from the recommendations and suggestions of expert review teams. If future MPGs were to include fewer mandatory reporting provisions, the review process may need to be adjusted to ensure that a broad set of relevant information is still being subject to facilitative review by experts, and not only information for which reporting provisions are mandatory. For Kyoto Protocol Parties, GHG inventory reporting was linked to compliance, making review processes focused on recommendations for data to be consistent, transparent, complete, accurate and comparable, and sensitive to improving the quality of national inventory preparation systems. Parties may consider the implications of review as they craft reporting guidelines, as this might influence the type of information guidelines will request or require.

23. Parties cannot report information they have not been able to track. As such, what Parties can report will be constrained by their domestic capacities to gather and process information. Support for improving these fundamental capacities, which in some cases may take years to develop fully, will be essential for the Paris Agreement's enhanced transparency framework to function and to actually enable the sharing of information that Parties want from each other. 
Table 2. Overview of reporting provisions of the enhanced transparency framework under the Paris Agreement and the MRV arrangements under the Cancún Agreements

\begin{tabular}{|c|c|c|c|c|c|}
\hline \multirow{4}{*}{$\begin{array}{l}\text { National GHG } \\
\text { inventories }\end{array}$} & \multicolumn{2}{|c|}{ Existing transparency system } & \multicolumn{3}{|c|}{ Enhanced transparency framework } \\
\hline & Annex I & Non-Annex I & $\begin{array}{l}\text { Developed Country } \\
\text { Parties }\end{array}$ & Developing Country Parties & $\begin{array}{l}\text { Other [non-developed] } \\
\text { Parties that provide support }\end{array}$ \\
\hline & Annual frequency & $\begin{array}{l}\text { Biennial frequency consistent with level of } \\
\text { support (as summarised in BURs), except } \\
\text { for LDCs and SIDS; much less frequent } \\
\text { in practice }\end{array}$ & Annual frequency ${ }^{1}$ & $\begin{array}{l}\text { Mandatory (shall) biennial reporting2 } \\
\text { (except for SIDS, LDCs, Parties } \\
\text { needing flexibility in light of their } \\
\text { capacities) }\end{array}$ & $\mathrm{N} / \mathrm{A}$ \\
\hline & $\begin{array}{l}\text { Mandatory use of } 2006 \\
\text { IPCC guidelines }\end{array}$ & $\begin{array}{l}\text { Non-mandatory use of revised } 1996 \\
\text { IPCC guidelines }\end{array}$ & \multicolumn{2}{|c|}{$\begin{array}{l}\text { Good practice methodologies to be used by all Parties. Flexibility in } \\
\text { scope, frequency and level of detail of reporting for developing } \\
\text { countries that need it in light of their capacities. }\end{array}$} & N/A \\
\hline $\begin{array}{l}\text { Mitigation targets and } \\
\text { actions (existing } \\
\text { system) and } \\
\text { NDCs under Article } 4 \\
\text { (Paris Agreement) }\end{array}$ & $\begin{array}{l}\text { Specific guidelines for } \\
\text { Biennial Reports }\end{array}$ & $\begin{array}{l}\text { Specific guidelines for Biennial Update } \\
\text { Reports }\end{array}$ & \multicolumn{2}{|c|}{$\begin{array}{l}\text { Common modalities, procedures and guidelines. Flexibility in } \\
\text { scope, frequency and level of detail of reporting for developing } \\
\text { countries that need it in light of their capacities. }\end{array}$} & $\mathrm{N} / \mathrm{A}$ \\
\hline Finance provided & $\begin{array}{l}\text { Biennial mandatory } \\
\text { reporting only for Annex II }\end{array}$ & $\mathrm{N} / \mathrm{A}$ & $\begin{array}{l}\text { Mandatory (shall) biennial } \\
\text { reporting² of transparent } \\
\text { and consistent information }\end{array}$ & N/A & $\begin{array}{l}\text { Non-mandatory (encouraged } \\
\text { to) biennial reporting }{ }^{2} \text { of } \\
\text { transparent and consistent } \\
\text { information }\end{array}$ \\
\hline $\begin{array}{l}\text { Financial support } \\
\text { received and needed }\end{array}$ & $\mathrm{N} / \mathrm{A}$ & Non-mandatory biennial reporting & $\mathrm{N} / \mathrm{A}$ & $\begin{array}{l}\text { Non-mandatory (should) biennial } \\
\text { reporting², including the use, impact } \\
\text { and estimated results thereof }\end{array}$ & $\mathrm{N} / \mathrm{A}$ \\
\hline
\end{tabular}

Note: "Developed” and “developing” countries are not defined under the UNFCCC or the Paris Agreement. ${ }^{1}$ : Paragraph 92(e) of the Decision 1/CP.21 says Parties need to maintain at least the frequency and quality of reporting in accordance with their respective obligations under the Convention; Annex I Parties are therefore assumed to continue to report national GHG inventories annually, as per their current obligations under the Convention. ${ }^{2}$ : "No less frequently than” biennially, as per Paragraph 90 of Decision 1/CP.21. ${ }^{3}$ : As specified in Paragraphs 89 and 90 of Decision 1/CP.21, and Article 13.2 of the Paris Agreement.

Source: Adapted from (Briner and Moarif, 2016, pp. 21, 22[3]). 


\section{Enhancement of mitigation reporting}

\subsection{Mitigation reporting within the Paris Agreement}

24. This section focuses on issues and options related to reporting information relevant to mitigation, particularly on greenhouse gas (GHG) emissions, and on progress with nationally determined contributions (NDCs) under Article 4. This paper draws on current experience with GHG inventories, mitigation information in reports submitted biennially, i.e. biennial reports (BRs) from Annex I Parties and biennial update reports (BURs) from non-Annex I Parties, ${ }^{3}$ and submitted nationally determined contributions (NDCs). ${ }^{4}$

25. The Paris Agreement is expected to lead to two significant changes in mitigation reporting. First, the manner in which Parties report this information shifts from a strict bifurcation between Annex I and non-Annex I Parties, to a more nuanced and varied application of flexibility (see Table 2). While this shift may better reflect the variations in country circumstances and capacities, such a transition may also introduce challenges and complexities into future reporting arrangements.

26. Parties' NDCs vary in line with different national circumstances and capacities. Future reporting provisions may combine information that can be reported by all countries regardless of NDC type, and some information that is only relevant to certain NDCs. The Paris Agreement singles out "developed country Parties" to continue with economy-wide absolute emission reduction targets (reflecting current practice), and encourages "developing country Parties" to move towards economy-wide reduction or limitation targets over time (Article 4.4 of the Paris Agreement). ${ }^{5}$ Nevertheless, in the medium term, there will likely continue to be much diversity between different Parties' NDCs.

27. Second, one of the purposes of the framework for transparency of action, to inform the global stocktake, is new in relation to current reporting under the UNFCCC. Aggregating information on current GHG emissions is challenging, as many countries have incomplete or out of date inventories, and have compiled these using different methods (Ellis and Moarif, 2015 ${ }_{[4]}$ ). The global stocktake may use inventory reporting from Parties as an input to take stock of current emissions levels. If the stocktake is to assess progress towards achieving the long-term mitigation goal of the Paris Agreement, it may also need information on estimated impacts of NDCs and estimated future emissions trajectories. At present, aggregating mitigation information on NDCs is challenging, as Parties have developed NDCs using widely different methods, expressed them using different metrics, and communicated with insufficient transparency about the

\footnotetext{
3 As presented in the introduction, this paper does not discuss national communications, though they include summary GHG inventory information and information on mitigation actions. This paper uses the term "progress reports" to refer to the reports containing information requested in Article 13.7b of the Paris Agreement, and assumes standalone national inventory reports will be reported separately.

${ }^{4}$ This paper uses the term NDC to refer to NDCs under Article 4.

${ }^{5}$ The terms “developed” and “developing” country Party are not defined under the UNFCCC.
} 
methods and metrics (UNFCCC, 2015 ${ }_{[6]}$ ). In the absence of common guidance, the use of international transfers of units under Article 6 could further complicate this exercise. In the case of both inventories and forward-looking GHG information, given the aggregation issues described above, the stocktake could incentivise more harmonised accounting and reporting; this may influence the development of related modalities, procedures and guidelines. ${ }^{6}$

28. Figure 1 lays out a view of how the reporting provisions for mitigation relate to other parts of the Paris Agreement. It also indicates the work programmes launched by Decision 1/CP.21, to further elaborate how these provisions may be implemented. In general, co-ordination between these and other related work programmes will be important to ensure coherence and efficiency (Dagnet et al., 2017 $[5]$ ). Figure 1 formulates reporting in terms of four major links:

1. Reporting and NDCs: As described above, the variety of NDCs leads to some variety in reporting. Some of the information needed to understand the NDC will differ, as will how the Party assesses progress with its NDC, and therefore the information it reports would reflect this. In addition, Parties "shall” implement mitigation measures with the aim of achieving their NDC objectives (Article 4.2 of the Paris Agreement). Given this is a mandatory provision Parties may need to report on not only on progress with quantified objectives, such as limiting GHG emissions by a specified amount, but also implementation of the measures taken to achieve this objective, such as afforestation and deployment of renewable energy. For some Parties, there may be no difference between NDC objectives and mitigation measures; this clarification could be communicated via reporting.

2. Reporting and communication of NDCs: An NDC is to be communicated with information to ensure its clarity, transparency and understanding (CTU). The extent to which this includes domestic mitigation measures is unclear and likely specific to different Parties. This information can, logically, be an essential basis for the information a Party will report biennially on progress with its NDC, and include elements such as intended use of international transfers under Article 6. There are two places in the Paris Agreement decision text that emphasise "methodological consistency" between the information Parties communicate with their NDC (including on baselines), and the information they communicate on the implementation of their NDC and the progress made towards achieving their NDC. What methodological consistency means in practice would need to be fleshed out in the particular contexts of accounting and reporting.

3. Reporting and accounting: To provide the information required by Article 13.7b, Parties would need to understand how to a) "account for" the achievement of their NDC once the target year is passed, and b) assess progress with their NDC while it is being implemented. As presented in Figure 1, the accounting guidance would be the means by which Parties understand how to assess progress and achievement of their NDC, in the manner appropriate to a given NDC. This

6 Parties could also decide to use top-down GHG emissions estimates rather than aggregate national GHG inventories. Top-down GHG emissions monitoring efforts can in some cases be used to highlight potentially incomplete inventory reporting, see for example (Weiss and Prinn, $2011_{[87]}$ ), (Levin et al., 2010 [88] $)$, (Keller et al., 2011 $\left.{ }_{[86]}\right)$ (Allen, 2014 ${ }_{[85]}$ ). 
information would then be reported, using the reporting guidelines. ${ }^{7}$ Accounting would include information relevant to use of international transfers under Article 6. A Party's NDC and its decision to use international transfers under Article 6 may impact how a Party prioritises data collection and sophisticated emissions estimations in sectors important to its NDC, or as needed to participate in cooperative approaches under Article 6. NDC accounting would likely rely on emissions data from the GHG inventory or on data used to compile the inventory, ${ }^{8}$ even though for some Parties the inventory's scope may not necessarily match the scope of gases and sectors encompassed by an NDC. Methodologies and metrics would also need to be consistent across accounting guidance and inventory reporting guidance.

4. Reporting and what comes after: Information communicated in the national inventory report and the progress report would be subject to technical expert review, and would likely also be inputs to the global stocktake process. The review process will examine the consistency of information reported with guidelines; this may also have implications for how countries craft the specific provisions of the guidance, such as the strength of the language (e.g. "shall” vs. "may"), the level of detail, and how information is to be presented. As mentioned, the global stocktake is a strong incentive for improving the consistency and completeness of information, particularly given the Paris Agreement decision text mentions information on the overall effect of NDCs as a potential input to the global stocktake (Paragraph 99). In practice, information on GHG emissions and the impacts of NDCs of the several dozen largest emitters may be sufficient for the purpose of understanding progress toward collective long-term temperature objectives.

\footnotetext{
${ }^{7}$ See also (Prasad, Ganesan and Gupta, 2017 ${ }_{[84]}$ ).

${ }^{8}$ The work of the GHG Platform India, SEEG Brazil and SEEG Peru provide excellent examples of data collection and methodology development, as well as thorough assessments of data quality and gaps. These are bottom-up civil society initiatives to understand and in some cases replicate national GHG emissions.
} 
Figure 1. Links between reporting provisions on mitigation and other key elements of the Paris Agreement

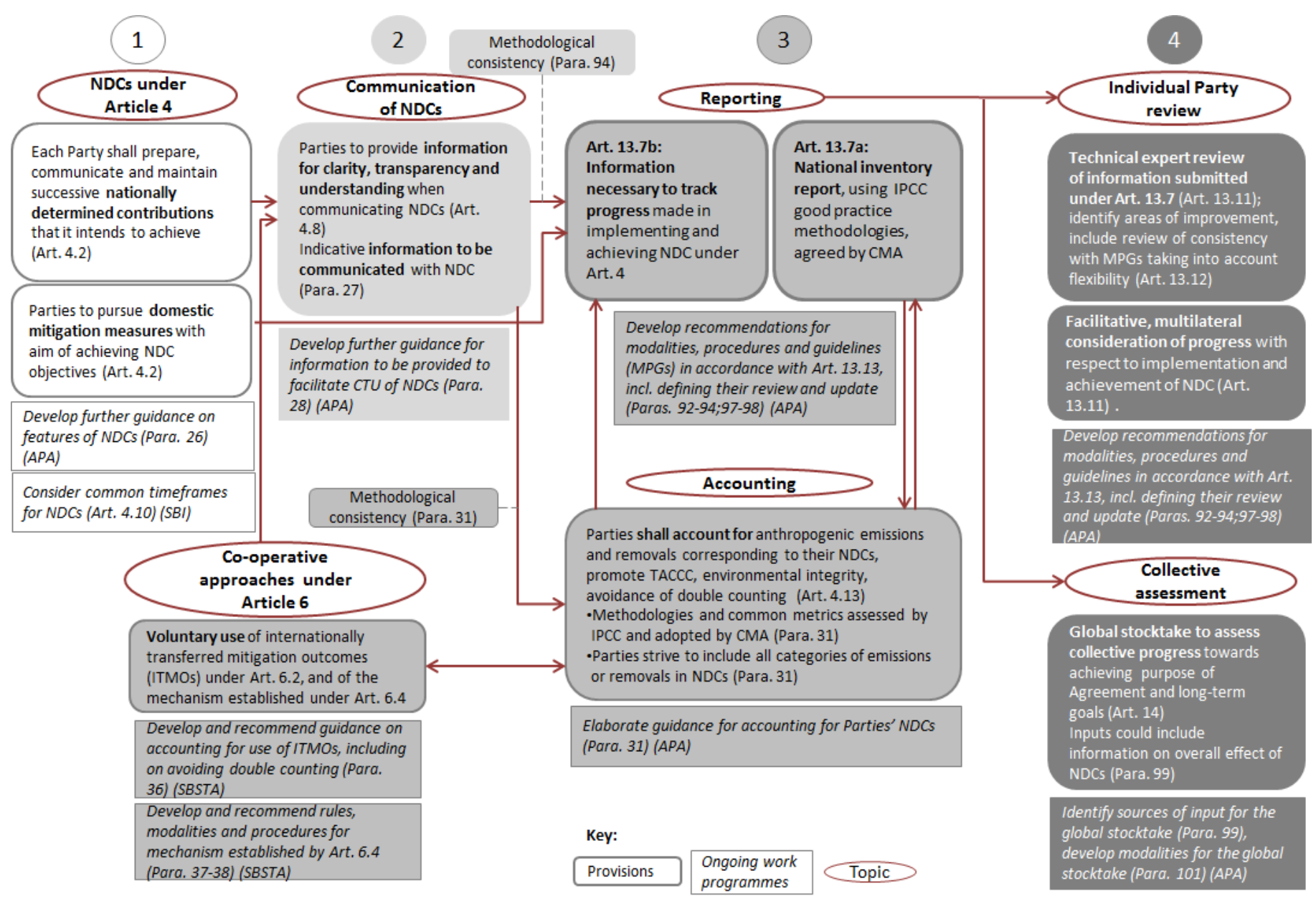

Note: Article numbers refer to the Paris Agreement and paragraph numbers refer to Decision 1/CP.21. 


\subsection{Information on greenhouse gas (GHG) emissions}

\subsubsection{Current reporting arrangements and key lessons learned}

29. Table 3 provides a brief overview of the current reporting requirements for GHG information. Currently, only Annex I Parties are required to report full GHG inventories in the form of a set of standardised Common Reporting Format (CRF) tables and a National Inventory Report (NIR). Non-Annex I Parties are also encouraged to report NIRs as part of their BURs. No specific guidance is provided on how to do so, though several non-Annex I Parties voluntarily use CRF tables and other guidance developed for Annex I inventory guidelines. CRF tables contain the (mostly) quantitative information and estimations on the Parties' emissions and removals of GHGs, and Annex I Parties report these electronically using an online interface (the CRF Reporter). The NIR provides a detailed and transparent explanation of the information contained in the inventory. This includes descriptions of methodologies used, data sources, recalculations and institutional arrangements for preparation of the inventory (including quality control and assurance procedures). This detailed inventory information, reported annually for Annex I Parties, is summarised in Annex I biennial reports. For an overview of the contents of current inventory reporting guidelines, see Table 15 in the Ann ex.

Table 3. Current reporting requirements for inventories

\begin{tabular}{|c|c|c|}
\hline Information & Annex I (NIR) ${ }^{1}$ & Non-Annex I (BUR) \\
\hline Total GHG emissions & Mandatory (summarised in NC and BR) & $\begin{array}{l}\text { Non-mandatory** (Total of all gases combined not } \\
\text { included in summary tables) }\end{array}$ \\
\hline $\begin{array}{l}\text { Coverage (Gases, sectors, } \\
\text { etc.) }\end{array}$ & $\begin{array}{l}\text { Mandatory (For } \mathrm{CO}_{2}, \mathrm{CH}_{4}, \mathrm{~N}_{2} \mathrm{O}, \mathrm{PFCs}, \mathrm{HFCs}, \mathrm{SF}_{6}, \mathrm{NF}_{3} \text { ) } \\
\text { (includes LULUCF) }\end{array}$ & $\begin{array}{l}\text { Mandatory (qualified) }{ }^{\star *}\left(\mathrm{CO}_{2}, \mathrm{CH}_{4}, \mathrm{~N}_{2} \mathrm{O}\right) \\
\text { (Shall, as appropriate and to the extent possible) }\end{array}$ \\
\hline Years covered & $\begin{array}{l}\text { Mandatory ( } 1990 \text { up to } 2 \text { years prior to current year [N- } \\
\text { 2]) }\end{array}$ & $\begin{array}{l}\text { Mandatory (not older than previous four years, or more } \\
\text { recent) (time series encouraged) }\end{array}$ \\
\hline Metrics & $\begin{array}{l}\text { Mandatory (GWPs for each sector and for a national total, } \\
\text { from 4th IPCC Assessment Report) }\end{array}$ & $\begin{array}{l}\text { Non-mandatory ** (should use IPCC GWPs if wish to } \\
\text { report aggregate GHG emissions and removals, from 2nd } \\
\text { IPCC Assessment Report) }\end{array}$ \\
\hline $\begin{array}{l}\text { National inventory systems } \\
\text { and arrangements }\end{array}$ & Mandatory (detailed in NIR, summary in BR) & $\begin{array}{l}\text { Non-mandatory **(encouraged to describe procedures } \\
\text { and arrangements undertaken to collect and archive data) }\end{array}$ \\
\hline Methods used & $\begin{array}{l}\text { Mandatory (2006 IPCC Guidelines; assumptions, } \\
\text { emission factors, activity data and rationale for their } \\
\text { selection, transparency for tier } 3 \text { models) }\end{array}$ & $\begin{array}{l}\text { Non-mandatory ** (should use Revised } 1996 \text { IPCC GL) } \\
\text { (in BR: Updates should also use IPCC Good Practice } \\
\text { Guidance and Uncertainty Management, Good Practice } \\
\text { Guidance for LULUCF encouraged) }\end{array}$ \\
\hline Common format for data & $\begin{array}{l}\text { Mandatory (CRF Reporter to produce Common Reporting } \\
\text { Format tables; data available online) }\end{array}$ & $\begin{array}{l}\text { Non-mandatory (encouraged to use tables presented in } \\
\text { guidelines) }\end{array}$ \\
\hline
\end{tabular}

Note: ** Guidelines for BURs cross-reference guidelines for NCs (Annex of Decision 17/CP.8)

${ }^{1}$ For Annex I countries, this column refers to the guidelines for annual inventory submissions in Decision 24/CP.19 (cross-referenced in the NC and BR reporting guidelines). ${ }^{2}$ Land-based approaches. ${ }^{3}$ Exceptions for Bulgaria, Croatia, Hungary, Poland, Romania and Slovenia. ${ }^{4}$ Inventory does not need to provide information on annual GHG emissions over a number of years.

Source: Adapted from Ellis and Moarif, 2015.

30. Non-Annex I Parties are required only to provide information on GHG emissions and removals in their BURs, rather than reporting stand-alone inventories. Some NonAnnex I Parties have reported a full NIR alongside their BUR, as encouraged in the BUR 
guidelines. ${ }^{9}$ The non-Annex I Inventory Software (NAIIS), a calculation tool as well as a reporting tool (i.e. Parties enter data and emissions are calculated), is available and intended to facilitate inventory preparation and reporting.

31. Inventory reporting is closely linked with the methods used to produce the inventory. While each country will have its own way of collecting, collating and processing data, and its own institutional structure for preparing the inventory, all countries are requested or required to follow inventory guidelines and other guidance developed by the Intergovernmental Panel on Climate Change (IPCC). The inventory guidelines are updated to account for improved scientific understanding, the most recent version being the 2006 IPCC guidelines for inventory preparation. As can be seen in Table 3, UNFCCC reporting guidelines make reference to the IPCC guidelines that Parties are to use to prepare their inventories (2006 IPCC guidelines for Annex I Parties, revised 1996 IPCC guidelines for non-Annex I parties), as well as methods that Parties are encouraged to use. BUR guidelines cross-reference national communication guidelines dating from 2001, and hence currently refer to the previous 1996 IPCC guidelines. Nevertheless, most Parties are using or planning to shift to using the 2006 IPCC guidelines (Borgogno, 2016 $6_{[7]}$ ), which provide different approaches for countries to estimate their GHG emissions, depending on how much data they have available and the level of methodological complexity they can use. ${ }^{10}$

32. While current experience with inventory reporting and the use of guidance is concentrated in Annex I countries, there has been increasing experience with communicating NIRs in several non-Annex I countries as well. Three major lessons from current experience with GHG reporting to date are (Ellis and Moarif, 2015 [4]); (Briner and Moarif, 2016 $\left.{ }_{[3]}\right)$; (Briner and Moarif, 2016 ${ }_{[1]}$ ):

- Experience from all Parties demonstrates that it takes time to be able to report a regular GHG inventory. This requires significant domestic information and data monitoring systems that can take years to put into place, and the development of permanent institutions and structures to undertake regular inventory compilation. Domestic policy processes and priorities can also provide strong incentives to develop robust monitoring systems, for example in the context of a national climate policy or objective.

\footnotetext{
${ }^{9}$ Armenia, Chile, Costa Rica, Ecuador, Georgia, Ghana, Mauritania, Moldova, Namibia, Serbia, South Africa. Some of these were prepared using capacity-building support provided for preparation of the national GHG inventory.

${ }^{10}$ At the lowest level, "Tier 1 ” methods use default emission factors. An emission factor is the rate of emission per unit of activity, output or input, e.g. a particular fossil fuel power plant has a $\mathrm{CO}_{2}$ emission factor of $0.765 \mathrm{~kg} / \mathrm{kWh}$ generated. The use of country-specific emission factors would be considered “Tier 2". The use of models for specific sectors to produce more accurate emission factors, for example, could be considered "Tier 3". In general, Tier 2 and 3 are considered more accurate and more appropriate for sources that contribute significantly to total GHG emissions. Most countries use a mixture of tiers and methods to develop their inventories, which are compiled using IPCC software or other dedicated software and tools. The IPCC software, the CRF reporter, and a range of other tools are available to help Parties undertake analyses, estimations and recalculations which are then reported in the NIR. The IPCC software currently covers Tier 1 methods, though Tier 2 capabilities are currently being added. Countries also use tools such as the IPCC spreadsheet for calculating methane emissions from landfills, and for Tier 3 methods will often use dedicated sectoral tools (e.g. COPERT software for road transport emissions in Europe).
} 
- There are significant gaps in the time series reporting of GHG information, with consequences for understanding global emissions and trends. For non-Annex I Parties, the provision of this information has been patchy, GHG data is significantly out of date (e.g. latest year reported in most non-Annex I inventories is before 2005), and the majority of Parties report inventories only for a single year or years (whether or not they may have collected time series data for domestic purposes).

- Having to regularly report a GHG inventory, combined with an external expert review system, are both key elements that helped to build up completeness, accuracy, consistency and comparability over time in Annex I Party inventories. In theory, BURs also involve a move towards more regular reporting combined with technical expert analysis for non-Annex I Parties, which could also help build up capacity, particularly when combined with capacity-building support. Some Parties have found that having to report has been helpful in building stronger domestic institutional arrangements for inventories, and can help identify where data and information are missing. ${ }^{11}$

33. Most Parties are already using the same inventory preparation guidelines, i.e. the 2006 IPCC guidelines. A key lesson is that having common guidelines has not meant Parties reporting the same information in the same way; the IPCC guidelines can be used by any country and allow for a significant degree of adaptability. Similarly, inventory reporting guidelines for Annex I Parties have provided a framework which can be (and is) adapted to different countries, in line with the particularities of their inventory and domestic arrangements. If a country can only report on a few sectors and one sectoral sub-category in each, e.g. on fuel combustion in energy and not fugitive emissions, then that is all it will estimate in its inventory and all it will report.

34. Domestic processes for monitoring, collecting and estimating GHG data are unlikely to be harmonised or standardised, particular since the more accurate the methods (Tier 2 and Tier 3), the more country- and/or sector-specific estimation methods and tools will be. Given this, reporting guidelines have enabled clarity and transparency regarding country-specific information, which both improves understanding of emissions and trends and provides greater confidence in the information reported.

35. The current inventory reporting guidelines (Decision 24/CP.19), which reflect use of the most recent IPCC inventory preparation guidelines, could be a reasonable starting point for developing inventory reporting guidelines under the Paris Agreement. Though they were written for Annex I Parties, the NIRs of several non-Annex I Parties follow many of the headings and sub-headings outlined for the NIR in Annex I inventory reporting guidelines (e.g. Chile, Georgia); with structured feedback from Parties they might be adapted for the purposes of the Paris Agreement.

36. Another important lesson is that "...general guidelines do not necessarily mean flexibility. On the contrary, detailed guidance may actually be more helpful for implementing the enhanced transparency framework [...]." (Brazil, Argentina and Uruguay, 2017 $\left.{ }_{[8]}\right)$. This lesson will hold true for reporting on all topics, particularly those for which only Annex I Parties have benefitted from guidelines with helpful details, recommendations and suggestions. The guidelines in Decision 24/CP.19 include advice

11 These points were raised by both developed and developing country participants during the CCXG Global Forum for the Environment and Climate Change, 11-12 September 2017. 
and suggestions that encourage certain practices or provide guidance on the type of information to be reported. The language used does not require specific information (i.e. using a "shall" provision), but rather lays out what these systems "should" be designed to achieve. Including facilitative language of this kind within guidelines is in line with one of the objectives of the inventory reporting guidelines: to help countries improve the quality of their inventories. Beyond what a Party must do to technically fulfil its reporting obligations, the guidelines contain suggested information to include on domestic institutional arrangements, including QA/QC measures, record-keeping and archiving, all of which are essential for developing, maintaining and improving sound GHG inventories (Carman, 2014 ${ }_{[9]}$ ) (Damassa, 2013 ${ }_{[10]}$ ).

37. Another lesson particularly relevant for inventory reporting is that guidelines need to be updated regularly, since they are linked to inventory methodology guidelines that are also updated in line with advancements in scientific understanding. Annex I Party reporting guidelines were revised in light of the shift to the use of 2006 IPCC guidelines, and reference to updated GWP values have been kept in an annex to the decision text (24/CP.19) rather than included in the guidelines themselves. Since GWP values have been updated in each IPCC Assessment Report, this allows for common values to be updated in line with scientific assessments rather than wait for the inventory preparation guidelines to be updated. ${ }^{12}$ Conversely, reporting guidelines for GHG information from non-Annex I Parties still refer to national communication guidelines, which have not been updated for over a decade. Non-Annex I Parties using the 2006 IPCC guidelines have had to use reporting guidelines that are either inadequate or were originally written for Annex I Parties.

38. The lack of updates in inventory reporting guidelines for non-Annex I Parties has also meant that non-Annex I Parties using the 2006 IPCC inventory guidelines have followed the more scientific approach to sectors contained in the guidelines when producing NIRs. This may not necessarily be the most useful approach for communicating GHG information in a manner that is policy relevant. In contrast, Annex I Parties report their inventory sectors in a slightly different manner than the 2006 IPCC guidelines, in order to better match sectors used in crafting mitigation objectives and policies, as well as in reporting on policies and measures. ${ }^{13}$

39. The IPCC will issue a refinement to the 2006 guidelines in 2019 to update, supplement and elaborate on the 2006 guidelines where gaps or out-of-date science have been identified, for example with improvements in default factors (more regional default values, or provision of a range with guidance on how to select from within the range). Future inventory reporting may need to build in time for Parties to test and use the

${ }^{12}$ The climate effects of GHGs relative to $\mathrm{CO}_{2}$ are generally evaluated using 100-year GWP values. However, scientific understanding of the impact of GHGs continues to deepen, and there is now greater awareness of the different climatic roles of long-lived (e.g. $\left.\mathrm{CO}_{2}\right)$ and short-lived (e.g. $\mathrm{CH}_{4}$ ) GHGs. GWP is an imperfect measure for these different roles, and is not related to temperature outcomes. However, there is no single metric that combines all relevant factors associated with comparing the climate effects of different GHGs, and within the UNFCCC Parties have continued to discuss the issue of metrics, including through a workshop on common metrics held in 2012.

13 The 2006 IPCC guideline category agriculture, forestry and other land-use (AFOLU) is separated into Agriculture (CRF 3) and Land use, land-use change and forestry (CRF 4) in NIR and CRF tables. 
refinement, to then update reporting guidelines and online reporting tools as needed. There is precedent for testing new inventory methods: Annex I Parties are currently encouraged to use recent supplementary methodologies, e.g. the IPCC supplementary guidance on wetlands, and then requested to communicate on their experience with using the methodology (FCCC/SBSTA/2013/5, para. 80). This type of process could potentially also be used to encourage testing and feedback on inventory reporting guidelines.

\subsubsection{Implications of Paris Agreement provisions and options for enhanced reporting}

40. For GHG inventories, the principal enhancement under the Paris Agreement stems from the need for all Parties to report national inventory reports at least biennially, with developed country Parties reporting these annually as at present. The provision that preparation of inventories will be based on a common set of methodologies builds on current practice, whereby countries preparing inventories are using or working towards using 2006 IPCC guidelines. If all Parties used the most recent inventory preparation guidelines, this would facilitate parts of the stocktake of collective progress, such as on knowing the overall level of current GHG emissions, and could be an important area of work for the Capacity Building Initiative for Transparency (CBIT) and other transparency-related initiatives. For the purpose of reporting guidelines, implementing the Paris Agreement's enhanced transparency framework implies greater harmonisation and consistency in how information is reported, for example, using common tabular formats, even if the content of such tables in terms of detail and completeness will likely varyDeveloping an easy-to-use online tool, which accounts for different country needs and preferences, could also facilitate reporting.

41. Drawing on the possible "headings and subheadings" of the MPGs listed in the Annex to the APA informal note (APA, 2017 $[11]$ ), Table 4 indicates where the headings and sub-headings relate to the current inventory reporting guidelines for Annex I Parties, and provides comments and suggestions drawing both on current practice and the Paris Agreement's provisions related to GHG inventory reporting. As can be seen from the table, the outline presented in the informal note broadly matches information that some Parties are currently reporting, and separates a description of the methods Parties use from how Parties report this information. In the current informal note, the sub-headings under reporting do not necessarily match those under methods, and there is no subheading for record keeping. Given the importance of sound record keeping for building capacity and institutional arrangements to enable inventory development, Parties may wish to consider maintaining this reporting category in the future guidelines.

42. The outline in the informal note includes a section on improvement plans, which is currently requested in national inventory reports for Annex I Parties but for which no specific guidance is provided. Parties may benefit from having more detailed guidance on identifying improvements, developing plans and prioritising action to address challenges. This guidance could also ensure Parties' reporting of capacity needs in relation to their inventories is consistent with their improvement plans. 
Table 4. Comments and suggestions on APA informal note outline: GHG inventories

\begin{tabular}{|c|c|c|c|}
\hline $\begin{array}{l}\text { APA non-paper } \\
\text { annex headings }\end{array}$ & $\begin{array}{l}\text { Section of } \\
\text { guidelines in } \\
\text { 24/CP.19 (see } \\
\text { Table } 15 \text { in Annex) } \\
\end{array}$ & Comments and suggestions & Relevant Paris Agreement provision \\
\hline $\begin{array}{l}\text { 1. Objectives and } \\
\text { Principles }\end{array}$ & Sections $A$ and $B$ & Separate objectives from Principles and Definitions. & \\
\hline 2. Definitions & Section B & $\begin{array}{l}\text { Define TACCC principles, as currently } \\
\text { Explicit reference to para. 92e principle. }\end{array}$ & $\begin{array}{l}\text { Parties to maintain at least the frequency and } \\
\text { quality of reporting in accordance with } \\
\text { respective obligations under the Convention } \\
\text { (Para. 92e) } \\
\text { TACCC in para. 92C }\end{array}$ \\
\hline $\begin{array}{l}\text { 3. National } \\
\text { circumstances and } \\
\text { institutional } \\
\text { arrangements }\end{array}$ & Sections $\mathrm{C}$ and $\mathrm{F}$ & $\begin{array}{l}\text { If no separate section on record keeping, include } \\
\text { here. There is currently no section in inventory } \\
\text { reporting guidelines for "national circumstances". } \\
\text { Specific elements that relate to national } \\
\text { circumstances are covered in different parts of the } \\
\text { guidelines and Chapters } 1 \text { and } 2 \text { of the NIR. Option to } \\
\text { have sub-headings specifying what national } \\
\text { circumstances will cover (e.g. background } \\
\text { information, trends). }\end{array}$ & \multirow[t]{2}{*}{$\begin{array}{l}\text { Facilitate improved reporting and transparency } \\
\text { over time (Para 90, para. 92a) }\end{array}$} \\
\hline $\begin{array}{l}\text { a) Inventory } \\
\text { planning, } \\
\text { preparation and } \\
\text { management }\end{array}$ & Section F & $\begin{array}{l}\text { Section } \mathrm{F} \text { contains no mandatory requirements; } \\
\text { include additional detailed suggestions and } \\
\text { explanatory language as needed. }\end{array}$ & \\
\hline 4. Methods & & $\begin{array}{l}\text { As at present, this would specify what methods to } \\
\text { use, with additional guidance on encouraged practice. }\end{array}$ & $\begin{array}{l}\text { Guidelines will be common } \\
\text { (Art. 13.7a; Art. 13.13; para. 92g) }\end{array}$ \\
\hline $\begin{array}{l}\text { a) Methodologies, } \\
\text { parameters and } \\
\text { data }\end{array}$ & Section $\mathrm{E}$ & $\begin{array}{l}\text { Move towards using same set of IPCC GL, make } \\
\text { reference to most recent set of IPCC GL unless } \\
\text { stated otherwise in CMA or COP decisions; provide } \\
\text { for use of various tiers, and transparency where using } \\
\text { different methodologies. }\end{array}$ & \multirow{2}{*}{$\begin{array}{l}\text { Information reported to inform the global } \\
\text { stocktake under Art. } 14 \text { (Art. 13.5, para. 99) } \\
\text { Guidelines will be common } \\
\text { (Art. 13.7a; Art. 13.13; para. 92g) } \\
\text { Facilitate improved reporting and transparency } \\
\text { over time } \\
\text { (Para 90, para. 92a) }\end{array}$} \\
\hline $\begin{array}{l}\text { b) Key category } \\
\text { analysis }\end{array}$ & Section $\mathrm{E}$ & $\begin{array}{l}\text { Specify tool to be used (e.g. IPCC software), or leave } \\
\text { open and request transparency about tool used. }\end{array}$ & \\
\hline c) Recalculations & Section $\mathrm{E}$ & To be consistent with most recent IPCC GL & \multirow{3}{*}{$\begin{array}{l}\text { Information reported to inform the global } \\
\text { stocktake under Art. } 14 \text { (Art. 13.5, para. 99) } \\
\text { Guidelines will be common } \\
\text { (Art. 13.7a; Art. 13.13; para. 92g) } \\
\text { Facilitate improved reporting and transparency } \\
\text { over time } \\
\text { (Para 90, para. 92a) }\end{array}$} \\
\hline $\begin{array}{l}\text { d) Uncertainty } \\
\text { assessment }\end{array}$ & Section $\mathrm{E}$ & As per most recent IPCC GL & \\
\hline $\begin{array}{l}\text { e) Assessment of } \\
\text { completeness }\end{array}$ & Section $\mathrm{G}(1)$ & $\begin{array}{l}\text { May be more appropriate as a reporting requirement } \\
\text { (use of notation keys), but could describe method } \\
\text { here. }\end{array}$ & \\
\hline f) $Q A / Q C$ & Section E & $\begin{array}{l}\text { Guidance on features of plans, to be elaborated by } \\
\text { countries. }\end{array}$ & $\begin{array}{l}\text { Facilitate improved reporting and transparency } \\
\text { over time (Para 90, para. 92a) }\end{array}$ \\
\hline 5. Metrics & $\begin{array}{l}\text { Section E, Section } \\
1.3 \text { of NIR, NIR } \\
\text { chapters } \\
\text { GWP values } \\
\text { referenced in } \\
\text { annex to Decision }\end{array}$ & $\begin{array}{l}\text { Unclear what is intended by "metrics". } \\
\text { Specify GWP values in a decision rather than in } \\
\text { guidelines themselves (to account for changes). } \\
\text { Could specify all countries use latest GWP values, in } \\
\text { addition to any other values/methods they can } \\
\text { choose to use (e.g. GTP). }\end{array}$ & $\begin{array}{l}\text { Guidelines will be common } \\
\text { (Art. 13.7a; Art. 13.13; para. 92g) } \\
\text { Information reported to inform the global } \\
\text { stocktake under Art. } 14 \text { (Art. 13.5, para. 99) }\end{array}$ \\
\hline $\begin{array}{l}\text { 6. Reporting } \\
\text { guidance }\end{array}$ & Section G & $\begin{array}{l}\text { As currently, this would more specifically lay out the } \\
\text { information to report. } \\
\text { Mandatory provisions could be qualified, e.g. "as } \\
\text { appropriate", "to the extent possible". } \\
\text { Include suggestions and advice (e.g. "should", } \\
\text { "encouraged") to help countries understand what } \\
\text { information is relevant and needed to understand } \\
\text { their inventory. Where helpful, provide additional } \\
\text { explanation of what the guidelines are requesting and } \\
\text { why. }\end{array}$ & $\begin{array}{l}\text { - Flexibility in implementation of provisions for } \\
\text { developing country Parties that need it in light } \\
\text { of their capacities (Art. 13.2, para. 89, para. } \\
\text { 92b) } \\
\text { - Guidelines will be common (Art. 13.7a; Art. } \\
\text { 13.13; para. 92g) } \\
\text { - Information reported to inform the global } \\
\text { stocktake under Art. } 14 \text { (Art. 13.5, para. 99) }\end{array}$ \\
\hline
\end{tabular}




\begin{tabular}{|c|c|c|c|}
\hline $\begin{array}{l}\text { APA non-paper } \\
\text { annex headings }\end{array}$ & $\begin{array}{l}\text { Section of } \\
\text { guidelines in } \\
\text { 24/CP.19 (see } \\
\text { Table } 15 \text { in Annex) }\end{array}$ & Comments and suggestions & Relevant Paris Agreement provision \\
\hline $\begin{array}{l}\text { a) Information on } \\
\text { methods }\end{array}$ & Section G (1) & $\begin{array}{l}\text { Including tiers used etc. Specify key category } \\
\text { analysis, uncertainty, recalculations, verification, } \\
\text { QA/QC etc. }\end{array}$ & $\begin{array}{l}\text { Facilitate improved reporting and transparency } \\
\text { over time (Para 90, para. 92a) }\end{array}$ \\
\hline $\begin{array}{l}\text { b) Sectors and } \\
\text { gases }\end{array}$ & Section G (1) & $\begin{array}{l}\text { Mix of "shall", "should" and "encouraged" for gas } \\
\text { coverage. } \\
\text { Determine common format for reporting on sectors, } \\
\text { potentially based on economic rather than IPCC } \\
\text { sector classification, to match NDC. }\end{array}$ & $\begin{array}{l}\text { Flexibility in implementation of provisions for } \\
\text { developing country Parties that need it in light } \\
\text { of their capacities (Art. 13.2, para. 89, para. } \\
\text { 92b) }\end{array}$ \\
\hline c) Time series & Section G (1) & $\begin{array}{l}\text { Require time series, given importance, with flexibility } \\
\text { on the base year and length of time series }\end{array}$ & $\begin{array}{l}\text { Facilitate improved reporting and transparency } \\
\text { over time (Para 90, para. 92a) }\end{array}$ \\
\hline d) Frequency & $\begin{array}{l}\text { Currently set by } \\
\text { Decision }\end{array}$ & $\begin{array}{l}\text { Determined by } 1 / C P .21 \\
\text { Parties unable to report biennially could put forward } \\
\text { goal of reporting an inventory every } X \text { years (e.g. for } \\
\text { SIDS, LDCs and developing country Parties who } \\
\text { need flexibility in the light of their capacities) }\end{array}$ & $\begin{array}{l}\text { Except for LDCS and SIDS, all parties to submit } \\
\text { NIR no less frequently than biennially (Para. } \\
90 \text { ) } \\
\text { Flexibility for developing country Parties that } \\
\text { need it in light of their capacities (Art. 13.2, } \\
\text { para. 89, para. 92b) }\end{array}$ \\
\hline $\begin{array}{l}\text { 7. Constraints and } \\
\text { CB needs }\end{array}$ & $\begin{array}{l}\text { Generic manner in } \\
\text { Section } 6 \text { of NCs } \\
\text { and Section } 5 \text { of } \\
\text { BURs }\end{array}$ & $\begin{array}{l}\text { Guidance on identifying and prioritising constraints } \\
\text { and needs } \\
\text { Cross reference section } 8\end{array}$ & \multirow{2}{*}{$\begin{array}{l}\text { Facilitate improved reporting and transparency } \\
\text { over time (Para 90, para. 92a) }\end{array}$} \\
\hline $\begin{array}{l}\text { 8. Improvement } \\
\text { plans }\end{array}$ & $\begin{array}{l}\text { Sections F, G (2), } \\
\text { NIR sector } \\
\text { chapters and } \\
\text { Chapter } 10\end{array}$ & $\begin{array}{l}\text { Guidance on what improvement plans could include } \\
\text { Prioritisation of planned improvements (to better } \\
\text { target resources). }\end{array}$ & \\
\hline $\begin{array}{l}\text { 9. Submission } \\
\text { process, reporting } \\
\text { formats and tables }\end{array}$ & $\begin{array}{l}\text { Detailed in Section } \\
\mathrm{G}, \mathrm{J}\end{array}$ & $\begin{array}{l}\text { Specify reporting tables, and reference online } \\
\text { reporting tool (e.g. version of current CRF Reporter), } \\
\text { specifying aggregation of gases. } \\
\text { Specify data will be available online } \\
\text { Helpful to have detailed outline of NIR as at present. } \\
\text { Provision for guidelines to be updates as needed. }\end{array}$ & $\begin{array}{l}\text { Information reported to inform the global } \\
\text { stocktake under Art. } 14 \text { (Art. 13.5, para. 99) } \\
\text { Facilitate improved reporting and transparency } \\
\text { over time (Para 90, para. 92a) }\end{array}$ \\
\hline
\end{tabular}

Notes: Article numbers refer to the Paris Agreement, paragraph numbers to Decision 1/CP.21.

Source: Decision 24/CP.19; APA, 2017a.

\subsection{Information on progress with implementation and achievement of NDCs}

\subsubsection{Current reporting arrangements and key lessons learned}

43. An overview of information currently required and requested from Parties in their BRs and BURs is presented in the Annex (Table 16). Overall, developed country Parties are required in their biennial reports to describe their economy-wide emission reduction targets (including conditions or assumptions), and report on progress with meeting these targets (including accounting for land use and the use of market mechanisms). They are also required to report on mitigation actions and their effects, and domestic institutional arrangements for monitoring, reporting, domestic compliance and verification. Finally, all developed country Parties are also required to report emissions projections to 2030, to indicate future GHG trends and the role that current policies and measures play in influencing that trend. Some developing country Parties choose to report projections voluntarily. When reviewing Biennial Reports, expert reviewers have made the most mitigation-related recommendations on the completeness and transparency of information on progress made towards the achievement of the quantified economy-wide emission reduction target, including the reporting of policies and measures and projections (UNFCCC, 2017 $[12])$. Both the completeness and transparency of this 
information has improved between Annex I Parties' first and second BRs (UNFCCC, $\left.2016_{[13]}\right)$, potentially as a result of such recommendations.

44. Other than summary information on GHG emissions, non-Annex I Parties are not required to provide specific information on their mitigation objectives - the guidelines state Parties "should" provide information on actions to mitigate climate change. If this information is reported, the BUR guidelines then say what information Parties shall report with respect to these mitigation actions, such as the nature and scope of its mitigation action(s), the coverage of the mitigation actions (e.g. gases, sectors), use of market mechanisms, methodologies and assumptions, progress with implementation, and the results, estimated outcomes, and emissions reductions associated with mitigation measures. Given the large variation in capacity and circumstances among countries, along with the short time period since BURs were established, most non-Annex I Parties have not produced a BUR, and among those that have, there is significant variation in completeness and transparency. BUR guidelines contain limited explanations regarding what specific information to report (such as on methodologies and assumptions related to mitigation actions and their effects), do not specify how best to present it (e.g. what to include in table form), and do not require or encourage reporting on topics relevant to understanding the mitigation targets of several non-Annex I Parties (e.g. GHG projections, LULUCF accounting).

45. While reporting on mitigation objectives under the Cancún Agreements framework only began in 2014, the following three lessons are potentially relevant for NDC-related reporting (Ellis and Moarif, 2015 $5_{[4]}$ ) (Briner and Moarif, 2016 ${ }_{[1]}$ ) (Briner and Moarif, 2016 $\left.{ }_{[3]}\right)$ :

- Making reporting of key information mandatory, i.e. using "shall" in reporting guidelines, tends to improve the completeness of the information reported. "Shall” reporting provisions for Annex I countries receive greater scrutiny and are subject to more specific recommendations from expert review teams during the international assessment and review process (IAR).

- Even where reporting is mandatory, such as the use of units from market-based mechanisms, information is less complete and transparent where there are no clear definitions, nor clear methods for determining the information in the first place. For example, under current reporting guidelines, it is not clear what "use" of units refers to (counted against what and when?), making this information difficult for Parties to report.

- Related to the point above, some information Parties are asked to report will be difficult to harmonise and compare, because the methods used to produce it will vary from country to country. For example, Parties use different methods to produce GHG emissions projections and to estimate the historical and future GHG reduction impacts of their policies and measures. In accounting for land-use emissions, Parties may choose among several recognised approaches. Similarly, assessing the impact of individual policies and measures is complex, and there is significant diversity in how Parties attempt to undertake such assessments (UNFCCC, 2016 ${ }_{[13]}$ ). In these cases, transparent communication on the methods and approaches a Party is using is essential to actually understanding its mitigation actions and their consequences, as well as to build trust that the Party is acting in good faith.

46. The above lessons underline the importance of guidelines containing suggestions and recommendations on what information will help improve the understanding of a 
Party's actions that reduce or limit GHG emissions. More guidance on what information countries should report, why this information is of interest, and how to present it, will be particularly helpful for countries with less experience and reporting capacity; as mentioned in section 3.2, Annex I inventory reporting guidelines currently include this type of useful guidance. The suggestions by expert review teams during IAR can provide useful guidance for Parties on how to improve their reporting; future reporting guidelines could usefully capture some of these suggestions and recommendations (UNFCCC, $\left.2017_{[12]}\right)$. Similarly to inventories, Parties will only be able to report what they are able to; if a Party has not assessed the impact of its policies, or has incomplete data about a sector covered by its NDC, it will not be able to report on this information. Guidance can help and encourage Parties to improve their monitoring - and therefore reporting - over time.

47. While the aim of Parties when developing non-Annex I BUR guidelines may have been to develop guidelines that were fully flexible and not burdensome, experience with the BUR guidelines has shown that open-ended and vague guidelines do not necessarily make reporting easier, especially for countries with limited capacity. A challenge several non-Annex I Parties have expressed is that BUR guidelines are not detailed enough to a) be helpful, and b) meet the wide range of national circumstances that different nonAnnex I Parties have. ${ }^{14}$ A non-Annex I country with an economy-wide mitigation target, or a target set against a projected future emissions level (e.g. business-as-usual emissions trajectory), is not required or requested to communicate information needed to understand such targets. Thus, the current guidelines do not provide any direction for how a Party with such a mitigation objective could communicate this transparently via its BUR.

\subsubsection{Implications of Paris Agreement provisions and options for enhanced reporting}

48. Most implications of the Paris Agreement relevant to reporting under Article 13.7b stem from: a) the nature of NDCs under Article 4, i.e. they are highly diverse, as are non-Annex I country pledges under the Cancún Agreements; and b) the aim of assessing collective progress with meeting the objectives of the Paris Agreement through the global stocktake exercise. Thus, future reporting guidelines could include specific and detailed guidance to facilitate reporting by all Parties. Such guidance could encompass information that all Parties can or should aim to report, as well as information relevant to the NDCs of a subset of Parties. For example, all Parties will need to report on the mitigation measures implemented to meet their NDCs. While the forms of NDCs differ, as part of reporting on progress, all Parties could aim to report the GHG emissions level associated with their NDC target. This would be relevant for NDCs set against a historic emissions level or a future projected emissions level, as well as whether the NDC was economy-wide or only covered certain sectors and gases. This information would also apply to NDCs which could be translated into GHG terms (e.g. a certain share of renewable energy in electricity generation or total energy usage). For some Parties, guidelines could outline how to report other non-GHG-related information that is relevant to their NDCs, such as on population and GDP levels for intensity-based NDC targets. For example, Parties with NDCs expressed in terms of GHG per GDP could

14 Discussions held during the September 2016 CCXG Global Forum, notably during Breakout Group 4, see summary slides. 
follow guidelines that specify: reporting currency; using constant vs. current terms; using the UN System of National Accounts guidelines on GDP; using the same year for both GHG and GDP data; ensuring the GHG data is reported using IPCC 2006 guidelines and is consistent with the sectors and gases covered in the NDC (Cheah, 2016 $6_{[14]}$ ).

49. Current Annex I guidelines for reporting on progress with mitigation objectives could potentially be adapted and used by other countries with economy-wide mitigation targets, though new guidance will be needed to cover information relevant to understanding all types of NDCs (see Figure 3 and Table 6 in (Briner and Moarif, $\left.2016_{[3]}\right)$ ). As outlined in Section 3.1, enabling clear and understandable reporting on progress with NDCs may have implications for accounting guidance. Parties will need guidance on how they can assess their progress, and use more consistent and common metrics relevant to different NDC types, so that they are able to report this information transparently.

50. There are two broad areas of reporting that Parties may need to consider more carefully given the variety of NDCs, particularly since these areas are currently included in the outline for reporting on NDCs in the annex to the informal note prepared by APA co-facilitators (APA, 2017 ${ }_{[11]}$ ). The first covers the description of the Party's NDC under Article 4, and its connection to mitigation policies and measures related to implementation and achievement of an NDC (corresponding to sections 4 and 6 of the outline, see Table 5). Annex I reporting guidelines treat mitigation measures as components within an economy-wide target, a legacy established by the system of multiyear national carbon budgets under the Kyoto Protocol. While treating mitigation measures as components within a broader target might be applicable to many countries' NDCs, but there are also several countries whose NDCs comprise a set of specific mitigation measures. In this case, Parties may report the same information under sections 4 and 6 of their progress report.

51. Several Parties with an NDC comprising a set of mitigation measures have also indicated the expected GHG abatement impact resulting from the measures (e.g. Lao PDR, Mongolia, Uganda). Reporting on progress could imply information on what the actual (historical) impact of the measure or measures has been. Annex I Parties are not required to report on this information in BRs for individual measures, though it is suggested. Most report on GHG impacts where they are possible to estimate for a given measure, or report on the impacts of a group of measures where interactions between measures make isolating the impact of a single measure difficult. This information tends to be less complete and transparent than other mitigation-related information in BRs, largely because providing it is technically complex and the information therefore not always available. ${ }^{15}$ Experience within the EU Monitoring Mechanism shows that countries report the actual historical impacts of the measures much less often than anticipated or estimated future impacts (Schoenefeld, Hildén and Jordan, 2016 [15]). Within BRs, there is also much inconsistency in how Parties classify different policies, which can lead to lack of clarity on which sectors a given mitigation measure covers and what type of policy it is (e.g. the EU Emissions Trading System was classified 17 different ways by 21 different Parties) (UNFCCC, 2016 ${ }_{[13]}$ ). Reporting mitigation

15 During the CCXG Global Forum in September 2017, several developed country Parties identified this as an area where expert reviewers often asked many questions, since estimation and therefore reporting was challenging. 
measures in a complete manner can be challenging where measures have other policy drivers and impacts, making it difficult to determine which measures should or should not be included, and how to characterise them. Given the complexity of the topic, information on mitigation measures will likely continue to be challenging to report in a standardised and comparable manner, suggesting that additional voluntary guidance might be helpful. This could include helping a Party clarify what is meant by a policy "measure", "action" or "plan" (as the scope of what Parties include can differ significantly), as well as how to explain the methods used to assess impacts (anticipated and historical).

52. In some cases, distinguishing a Party's NDC from the mitigation measures intended to achieve it may not be clear for an outside observer. For example: A Party communicates a GHG reduction target against a projected business-as-usual (BAU) level, broken down as an energy-intensity reduction target (per GDP unit) and a target to increase forest cover. Are the latter two targets the "measures" that will enable achievement of the GHG target, or does the Party need to report additional policy measures? If a Party communicates a renewable energy target, and indicates it will also reduce emissions in two other sectors and improve energy efficiency, does it only need to report mitigation measures related to achieving its renewable energy target? Or should the Party also report on policies taken in the other sectors mentioned in its NDC communication? Future reporting arrangements should clarify such issues for Parties.

53. The second area of reporting Parties will need to consider is on emissions projections (corresponding to section 8 in Table 5). Forecasted emissions projections give an overall indication of how Parties think their emissions might evolve going forward, including as a result of the various mitigation measures they have undertaken (or will undertake). Providing a projection of GHG levels from the present to the NDC target year, for example, can indicate how well a Party's current policies are putting it on track towards meeting its target. As such, projections can be a useful way for Parties to communicate on their progress with implementing and achieving their NDC. However, for Parties expressing their NDCs as reductions against a reference or baseline emissions scenario, i.e. where the target level is projected, emissions projections will be essential to tracking progress with their NDC, and may require additional guidance (e.g. on recalculations depending on whether the Party has a fixed or dynamic baseline scenario, see (WRI, 2014 $[16]$ ). It may be that specific guidance will be needed under section 4a or $5 \mathrm{a}$ of the current APA outline (indicators to track progress in implementing and achieving NDC) on projections as they relate to NDCs based on projected emissions scenarios. Parties may wish to consider whether this guidance would need to differ from the guidance related to projections in section 8 of the outline.

54. Explicit mention of the global stocktake in Article 13.5 also implies the need for reporting more complete information on expected emissions levels, i.e. emissions projections from a much greater number of Parties. This suggests that even if Parties would not normally report projections in the context of indicating progress with their NDC, they might be asked to report these anyway under section 8 of the outline. Though most Parties have an NDC target for a single year, for the purpose of being useful to the global stocktake projections would likely need to indicate an emissions trajectory; a projected number referring to emissions levels in 2030, for example, would be less useful. Single year targets also lead to complications when it comes to accounting for the use of international transfers under Article 6 (Prag, Hood and Barata, 2013 ${ }_{[17]}$ ); where relevant, including the intended use of units in projections could also be a useful indicator for the global stocktake. 
55. Table 5 relates the possible headings and sub-headings of the MPGs, presented in the informal note on reporting on progress with NDCs (APA, 2017 $[11]$ ), with where this information is currently reported, as relevant. It then provides comments and suggestions related to the outline suggested by the headings, and the potential content of the different sections. In some cases, the content that would be covered by a given sub-heading is not clear, for example the separation of progress made in implementing vs. achieving an NDC. Is the distinction one of time, i.e. "achievement" occurs after the NDC period is over, while "implementation" refers to progress during the NDC period? Or is information on "implementation" about how much a Party has progressed, while information on "achievement" is about the likelihood of the Party reaching its target? The specific meaning of these terms may have different implications for how the reporting guidelines frame information on policies and measures, as well as information on projections.

56. In addition to the distinction between progress made in implementing vs. achieving an NDC, Parties may wish to clarify what information on "national circumstances” might cover, and whether guidance on indicators to track progress towards mitigation targets are to be developed as part of the reporting or accounting guidance. The table includes suggestions for re-ordering some of the heading and subheadings, to clarify the relation between different sets of information, and what they will be used for. For example, if Parties are asked to report on their use of international transfers under Article 6, this should be linked to reporting on progress with the NDC. 
Table 5. Comments and suggestions on APA informal note outline: Progress with NDCs

\begin{tabular}{|c|c|c|c|}
\hline $\begin{array}{l}\text { APA non-paper annex } \\
\text { outline }\end{array}$ & $\begin{array}{l}\text { Relation to current } \\
\text { reporting (Table 16) }\end{array}$ & Comments and suggestions & Relevant Paris Agreement provision \\
\hline 1. Objectives and Principles & $\begin{array}{l}\text { Only objectives, incl. } \\
\text { ensuring or encouraging } \\
\text { transparent, consistent, } \\
\text { complete accurate, timely } \\
\text { (and for BRs, comparable) } \\
\text { information. }\end{array}$ & $\begin{array}{l}\text { Separate objectives from principles, and } \\
\text { include definitions of principles, e.g. what is } \\
\text { a policy "measure" (vs. "action"), what is } \\
\text { "transparency" in this context, or } \\
\text { "completeness"1 } \\
\text { Include reference to para. 92e upfront }\end{array}$ & $\begin{array}{l}\text { Parties to maintain at least the frequency } \\
\text { and quality of reporting in accordance } \\
\text { with respective obligations under the } \\
\text { Convention (Para. 92e) }\end{array}$ \\
\hline $\begin{array}{l}\text { 2. National circumstances and } \\
\text { institutional arrangements }\end{array}$ & $\begin{array}{l}\text { Natl. circumstances only } \\
\text { in NCs } \\
\text { Institutional } \\
\text { arrangements: } 4 \mathrm{~A} \text { of } \mathrm{BR} \text {, } \\
\text { requested in Section } 4 \text { of } \\
\text { BUR }\end{array}$ & $\begin{array}{l}\text { Natl. circumstances unlikely to change } \\
\text { biennially, leave in NC } \\
\text { Specify institutional arrangements and } \\
\text { national systems related to the NDC, } \\
\text { covering formulation, implementation and } \\
\text { tracking, potentially include as subset of } \\
\text { NDC description }\end{array}$ & $\begin{array}{l}\text { Parties provide information necessary for } \\
\text { clarity, transparency and understanding } \\
\text { when communicating NDCs (Art. 4.8) }\end{array}$ \\
\hline $\begin{array}{l}\text { 3. Description of Party"s NDC } \\
\text { under Art. } 4 \text {, including } \\
\text { updates }\end{array}$ & Section 3 of BR & $\begin{array}{l}\text { Refer to information communicated for CTU; } \\
\text { opportunity to update } \\
\text { Opportunity to clarify what Party considers } \\
\text { to be its NDC vs. mitigation measures } \\
\text { designed to implement NDC } \\
\text { Include guidance on how to demonstrate } \\
\text { methodological consistency }{ }^{2}\end{array}$ & $\begin{array}{l}\text { Consistency between methodology } \\
\text { communicated in NDC and methodology } \\
\text { for reporting on progress made towards } \\
\text { achieving NDCs (Para 94c) }\end{array}$ \\
\hline $\begin{array}{l}\text { 4. Progress made in } \\
\text { implementing its NDC under } \\
\text { Art } 4 \text { to date } \\
\qquad 4 a) \text { Indicators to track } \\
\text { progress in implementing its } \\
\text { NDC under Art. } 4\end{array}$ & $\begin{array}{l}\text { BR refers to progress with } \\
\text { achievement }\end{array}$ & $\begin{array}{l}\text { If refers to current NDC, reporting would } \\
\text { vary by NDC, and include projections and/or } \\
\text { a description of domestic mitigation } \\
\text { measures, as relevant. } \\
\text { Include information covered under sections } \\
6,8,9 \text { and } 10 \text { of column } 1 . \\
\text { Mandatory provisions could be qualified, } \\
\text { e.g. "as appropriate", "to the extent possible" } \\
\text { Parties with conditional NDCs could explain } \\
\text { how they assess progress }\end{array}$ & \multirow{3}{*}{$\begin{array}{l}\text { - Parties prepare, communicate and } \\
\text { maintain NDCs, and communicate these } \\
\text { every five years (Art. 4.2, Art. 4.9) } \\
\text { - Parties pursue domestic mitigation } \\
\text { measures with the aim of achieving } \\
\text { objectives of NDCs (Art. 4.2) } \\
\text { - Parties account for their NDCs (Art. } \\
\text { 4.13, para. 31) } \\
\text { - Facilitate improved reporting and } \\
\text { transparency over time (Para 90, para. } \\
\text { 92a) } \\
\text { - Flexibility in implementation of } \\
\text { provisions for developing country Parties } \\
\text { that need it in light of their capacities (Art. } \\
\text { 13.2, para. 89, para. 92b, para. 94a) } \\
\text { - Facilitate improved reporting and } \\
\text { transparency over time (Para 90, para. } \\
\text { 92a) } \\
\text { Information reported to inform the global } \\
\text { stocktake under Art. } 14 \text { (Art. 13.5, para. } \\
\text { 99) } \\
\text { - Parties pursue domestic mitigation } \\
\text { measures with the aim of achieving } \\
\text { objectives of NDCs (Art. 4.2) } \\
\text { - Parties account for their NDCs (Art. } \\
\text { 4.13, para. 31) } \\
\text { - Consistency between methodology } \\
\text { communicated in NDC and methodology } \\
\text { for reporting on progress made towards } \\
\text { achieving NDCs (Para 94c) }\end{array}$} \\
\hline $\begin{array}{l}\text { 5. Progress made in achieving } \\
\text { its NDC under Art } 4 \text { for the } \\
\text { target year/period } \\
\text { 5a) Indicators to track } \\
\text { progress in achieving its NDC } \\
\text { under Art. } 4\end{array}$ & $\begin{array}{l}\text { Section } 4 \text { of BR, applies } \\
\text { to mitigation targets } \\
\text { currently being } \\
\text { implemented (and, after } \\
2020 \text {, their achievement) }\end{array}$ & $\begin{array}{l}\text { Progress with achieving an NDC may refer } \\
\text { to reporting on actual achievement of the } \\
\text { NDC, following completion of the NDC } \\
\text { period. In this case, reporting would include } \\
\text { similar NDC-specific information as above, } \\
\text { and any accounting guidance specific to } \\
\text { completed NDC. } \\
\text { If this is meant to assess the likelihood of a } \\
\text { Party achieving its target, there might be } \\
\text { overlaps with section } 8 \text { (projections). }\end{array}$ & \\
\hline $\begin{array}{l}\text { 6. Mitigation policies and } \\
\text { measures, actions and plans, } \\
\text { and other actions with } \\
\text { mitigation co-benefits, related } \\
\text { to the implementation and } \\
\text { achievement of an NDC under } \\
\text { Art. 4, including effects } \\
\text { (historical and expected), } \\
\text { barriers and costs }\end{array}$ & $\begin{array}{l}\text { Currently under section } 4 \\
\text { of BR } \\
\text { Aggregate effects of all } \\
\text { policies and measures } \\
\text { included in reporting of } \\
\text { projections (section 5) }\end{array}$ & $\begin{array}{l}\text { Potentially include under tracking of } \\
\text { progress with implementing NDC, since } \\
\text { Parties have obligation to implement } \\
\text { domestic measures } \\
\text { Overlap with section } 6 \text { if NDC comprises a } \\
\text { set of policies and measures } \\
\text { Some information is challenging to estimate } \\
\text { and report (e.g. costs, effects) } \\
\text { Emphasise historical effects, important to } \\
\text { assess progress against intended or } \\
\text { estimated effects communicated in NDC. }\end{array}$ & \\
\hline $\begin{array}{l}\text { 7. Summary of GHG } \\
\text { emissions and removals, as } \\
\text { applicable }\end{array}$ & $\begin{array}{l}\text { Section } 2 \text { of BR } \\
\text { Section } 3 \text { of BUR }\end{array}$ & $\begin{array}{l}\text { Move up to the beginning of the report, is } \\
\text { useful contextual information. }\end{array}$ & \\
\hline
\end{tabular}




\begin{tabular}{|c|c|c|c|}
\hline $\begin{array}{l}\text { APA non-paper annex } \\
\text { outline }\end{array}$ & $\begin{array}{l}\text { Relation to current } \\
\text { reporting (Table 16) }\end{array}$ & Comments and suggestions & Relevant Paris Agreement provision \\
\hline $\begin{array}{l}\text { 8. Projections of GHG } \\
\text { emissions and removals, as } \\
\text { applicable }\end{array}$ & $\begin{array}{l}\text { Section } 5 \text { of BR (cross } \\
\text { reference Annex I NC } \\
\text { guidelines which require } \\
\text { updating) }\end{array}$ & $\begin{array}{l}\text { Potentially include under tracking of } \\
\text { progress with achievement, if this is meant } \\
\text { to cover information on the likelihood of a } \\
\text { Party achieving its target. Clarify difference } \\
\text { between guidance for information reported } \\
\text { here vs. information needed to track } \\
\text { progress with NDCs comprising projected } \\
\text { target levels. } \\
\text { Provide up-to-date and detailed, facilitative } \\
\text { guidance. } \\
\text { Encourage all Parties to report projections } \\
\text { over the entire NDC period. } \\
\text { Request supplementary information from } \\
\text { Parties using Art. } 6 \text {. }\end{array}$ & $\begin{array}{l}\text { Information reported to inform the global } \\
\text { stocktake under Art. } 14 \text { (Art. 13.5, para. } \\
\text { 99) } \\
\text { Parties account for their NDCs (Art. 4.13, } \\
\text { para. 31) }\end{array}$ \\
\hline $\begin{array}{l}\text { 9. Info on parties" accounting } \\
\text { under Art. } 4.13 \text { and } 4.14\end{array}$ & $\begin{array}{l}\text { Included in Section } 4 \text { of } \\
\text { BR }\end{array}$ & $\begin{array}{l}\text { Include as sub-section of reporting on } \\
\text { progress; accounting for NDC would follow } \\
\text { guidance developed by APA under para. } 31 \\
\text { and include LULUCF and Art. } 6 \text { accounting } \\
\text { Request transparency on methods and } \\
\text { assumptions used when accounting for } \\
\text { progress (i.e. not just outcomes) } \\
\text { Art. } 4.14 \text { refers to existing experience - } \\
\text { unclear what would be reported here }\end{array}$ & $\begin{array}{l}\text { - Parties account for their NDCs (Art. } \\
\text { 4.13, para. 31) } \\
\text { - Facilitate improved reporting and } \\
\text { transparency over time (Para 90, para. } \\
\text { 92a) } \\
\text { - Information reported to inform the } \\
\text { global stocktake under Art. } 14 \text { (Art. 13.5, } \\
\text { para. 99) }\end{array}$ \\
\hline $\begin{array}{l}\text { 10. Info related to Art. 6, as } \\
\text { applicable }\end{array}$ & $\begin{array}{l}\text { Included in Section } 4 \text { of } \\
\text { BR }\end{array}$ & $\begin{array}{l}\text { Include as sub-section of reporting on } \\
\text { progress }^{3}\end{array}$ & $\begin{array}{l}\text { Parties account for their NDCs (Art. 4.13, } \\
\text { para. 31) }\end{array}$ \\
\hline $\begin{array}{l}\text { 11. Other information, where } \\
\text { applicable and appropriate }\end{array}$ & Section 7 of BR & $\begin{array}{l}\text { Leave open-ended language, and/or use to } \\
\text { encourage reporting of specific information. }\end{array}$ & $\begin{array}{l}\text { Facilitate improved reporting and } \\
\text { transparency over time (Para 90, para. } \\
92 \mathrm{a})\end{array}$ \\
\hline 12. Capacity building needs & $\begin{array}{l}\text { Section } 5 \text { of BUR, part of } \\
\text { reporting on both support } \\
\text { needs and support } \\
\text { received }\end{array}$ & $\begin{array}{l}\text { Specify what is to be reported, e.g. } \\
\text { capacities needed to implement NDC, MRV } \\
\text { the NDC, report to UNFCCC } \\
\text { Cross reference section } 13 \text {, challenges } \\
\text { reported in sections } 4 \text { or } 5 \text {, and other } \\
\text { reporting on support needs }\end{array}$ & $\begin{array}{l}\text { Facilitate improved reporting and } \\
\text { transparency over time (Para 90, para. } \\
92 \mathrm{a} \text { ) }\end{array}$ \\
\hline 13. Improvement plan & $\begin{array}{l}\mathrm{N} / \mathrm{A} \text { (borrows from } \\
\text { inventory reporting) }\end{array}$ & $\begin{array}{l}\text { Specify what the plan refers to: } \\
\text { implementation of NDC, information Party } \\
\text { wants to be able to report (or report more } \\
\text { fully), or both. } \\
\text { Parties could explain challenges with } \\
\text { reporting and/or implementation } \\
\text { Request prioritisation of actions Party will } \\
\text { undertake by next progress report. }\end{array}$ & $\begin{array}{l}\text { Facilitate improved reporting and } \\
\text { transparency over time (Para 90, para. } \\
92 \mathrm{a} \text { ) }\end{array}$ \\
\hline 14. Reporting format & $\begin{array}{l}\text { Section } 8 \text { of BR } \\
\text { Section } 9 \text { of BUR }\end{array}$ & $\begin{array}{l}\text { Specify use of common or harmonised } \\
\text { reporting formats and tables where possible } \\
\text { Have tables as easy to understand as } \\
\text { possible, with clarity on what each heading } \\
\text { or row contains } \\
\text { Refer to updates of guidelines }\end{array}$ & $\begin{array}{l}\text { Facilitate improved reporting and } \\
\text { transparency over time (Para 90, para. } \\
\text { 92a) } \\
\text { Information reported to inform the global } \\
\text { stocktake under Art. } 14 \text { (Art. 13.5, para. } \\
\text { 99) } \\
\text { APA to define year of first and } \\
\text { subsequent review of Article 13 MPGs } \\
\text { (Para. 91) }\end{array}$ \\
\hline
\end{tabular}

Note: Article numbers refer to the Paris Agreement, paragraph numbers to Decision 1/CP.21. ${ }^{1}$ Para. 92c mentions TACCC principles in relation to the transparency framework; these terms have specific definitions in the context of inventory reporting which may not all equally apply to NDC reporting. The EU Monitoring Mechanism, for example, defines "completeness", "consistency", "comparability" and "transparency" in relation to reporting on policies and measures. No definition of "measures" also means inconsistent reporting. ${ }^{2}$ For example on baselines, Parties could specify whether these are static or dynamic (recalculation policy if latter), which policies included and cut-off year, projection methods, assumptions for key drivers and data sources for key drivers. ${ }^{3}$ Parties would need to decide if other information relevant to Article 6, such as environmental integrity, avoidance of double counting, additional nature of emissions reductions, etc. would be reported here or elsewhere.

Source: (APA, 2017[11]); Decision 1/CP.21; Decision 2/CP.17; (Schoenefeld, Hildén and Jordan, 2016 $[15]$ ); (Levin, 2016 $[18]$ ). 


\section{Enhancement of finance reporting - finance provided and mobilised}

57. There are two main changes introduced by the Paris Agreement with respect to the reporting of finance provided and mobilised. First, the scope of Parties requested to report is widened from the group of "Annex II" Parties ${ }^{16}$ to a less clearly-defined set of "developed country Parties" and "other [developing country] Parties providing support" (Art.13.9). Second, the reporting of private finance mobilised by public interventions becomes mandatory for all developed countries, while it was previously voluntary for Annex II Parties and only focused on finance mobilised by public bilateral (not multilateral) contributions. If fully met, the provisions will deliver a more comprehensive coverage of climate finance provided and mobilised than current reporting arrangements, with implications for the development of the common modalities, procedures and guidelines (MPGs) for reporting under the enhanced transparency framework (see section 5.3).

58. Figure 2 illustrates how the reporting provisions for finance provided and mobilised relate to other key provisions of the Paris Agreement. It also indicates the work programmes launched by Decision 1/CP.21 to further elaborate how these provisions may be implemented. It highlights three main links:

1. Reporting and provision of financial support: The distinction between Paris Agreement provisions with mandatory and non-mandatory characteristics could have implications for the level of detail and content of information Parties report. Developed country Parties have a mandatory requirement to provide financial resources and to report on the level of climate finance provided ("shall"). Developed country Parties are also requested ("should") to take the lead on mobilising finance from a wide variety of sources. This distinction could be interpreted to place, indirectly, more emphasis on reporting on finance provided over finance mobilised. However, the reporting provisions for finance provided and mobilised are expressed in similar terms under Article 9.7 ("shall" for developed country Parties, "encouraged" for others).

2. Reporting and accounting: Defining modalities that ensure Parties provide transparent and consistent information is necessary to allow the implementation of the main reporting requirement under Article 9.7. Although there is no specific provision in the Paris Agreement with respect to accounting of finance provided and mobilised, a work programme under the Subsidiary Body for Scientific and Technological Advice (SBSTA) aims to fulfil that role. It is important that the substantive outcomes from these SBSTA deliberations are reflected in the structure and content of the MPGs, as the APA non-paper's draft headings and sub-headings on reporting recognise (APA, 2017 ${ }_{[11]}$ ).

16 Annex II Parties are listed in the 1992 United Nations Framework Convention on Climate Change, amended by decision 26/CP.7: Australia, Austria, Belgium, Canada, Denmark, European Union, Finland, France, Germany, Greece, Iceland, Ireland, Italy, Japan, Luxembourg, Netherlands, New Zealand, Norway, Portugal, Spain, Sweden, Switzerland, United Kingdom, United States. 
3. Reporting and review/collective assessment: The consideration of support provided by Parties is one of the key components of the technical expert review at the Party level and will be at least partly based on Parties' reporting under Article 9.7. As this review includes a "review of the consistency of the information with the MPGs", the design of MPGs has resource implications: the more detailed the reporting required or requested by the MPGs, the more resource intensive this review is likely to be. Finally, one of the purposes of the framework for transparency of support is to provide a full overview of aggregate financial support provided, to inform the global stocktake to the extent possible. Therefore the content of MPGs with regards to finance provided and mobilised would ideally facilitate aggregation of information.

Figure 2. Links between financial support reporting provisions, relevant work programmes and other key elements of the Paris Agreement

1



Develop modalities for accounting of financial resources provided and mobilised through public interventions in accordance with Art. 9.7 by COP 24 (Para 57) (SBSTA).
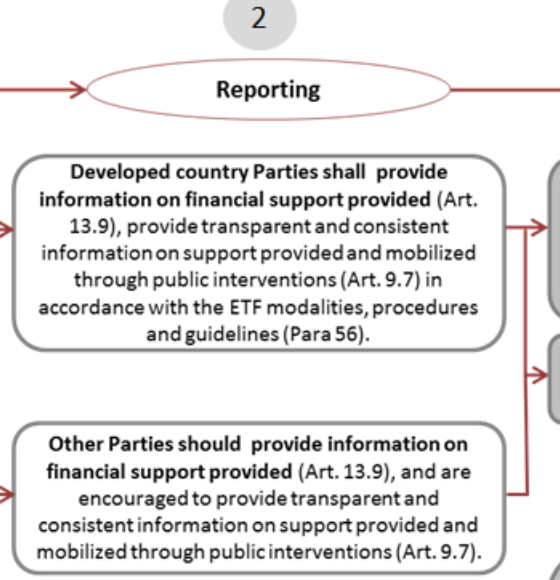

Develop recommendations for modalities, procedures and guidelines (MPGs) in accordance with Art. 13.13, incl. defining their review and update (Paras. 91, 94d) (APA)

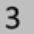

3

Individual Party

review

Technical expert review of information submitted under Art. 13.9, consisting of a consideration of support provided (Art. 13.11); identify areas of improvement, include review of consistency with MPGs taking into account flexibility (Art. 13.12)

Each Party shall participate in a facilitative, multilateral consideration of, i.a. progress with respect to efforts under Article 9 (Art. 13.11). (1)

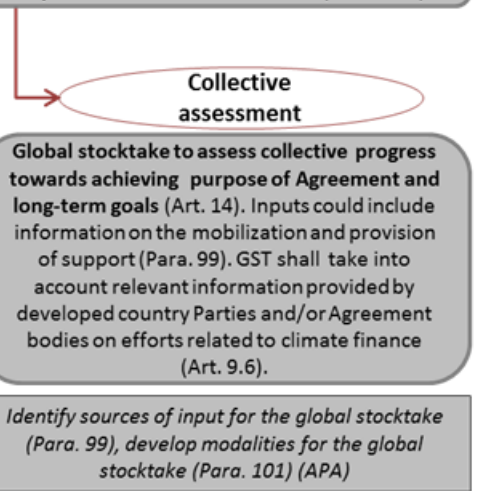

Key:

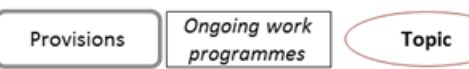

Note: The numbers "1", “2” and "3” refer to the three links described in the above paragraph. Article numbers refer to the Paris Agreement and paragraph numbers refer to Decision 1/CP.21.

59. The following sections present, for both finance provided and mobilised, key lessons from the current reporting experience under the Cancún arrangements (sections 4.1.1 and 4.2.1), drawing mainly from Annex I Parties' biennial reports (BRs) but also from some non-Annex I biennial update reports (BURs), as well as existing reporting arrangements outside of UNFCCC (sections 4.1.2 and 4.2.2). The last section suggests what an enhanced reporting system could look like for developed countries and other countries providing and mobilising climate finance, in line with the requirements of the Paris Agreement (section 4.3). 


\subsection{Finance provided}

\subsubsection{Key lessons from current reporting experience}

60. Reporting information on the provision of financial resources to developing country Parties is mandatory for Parties included in Annex II of the Convention, consisting of 23 countries and the European Union. ${ }^{17}$ Parties listed in Annex II are a subset of countries listed in Annex I of the Convention. Annex II Parties report through two vehicles:

- their national communications (NCs), which are to be submitted every four years, as per the NCs guidelines for Annex I Parties adopted in decision 4/CP.5 (UNFCCC, $2000_{[19])}{ }^{18}$

- their BRs, as per the guidelines adopted in Decision 2/CP.17 (UNFCCC, 2011 [20]) and the common tabular format (CTF) tables adopted in decision 19/CP.18 (UNFCCC, $\left.2013_{[21]}\right)$.

61. In both their BRs and NCs, Annex II Parties need to include the amount of financial resources provided, and give an indication of what new and additional financial resources they have provided pursuant to Art. 4.3 of the Convention. Article 4.3 mandates ("shall") Annex II Parties to meet the agreed full costs incurred by developing country Parties in complying with the communication of information related to implementation of the Convention under its Art. 12.1. ${ }^{19}$ Annex II Parties also need to clarify how they determined that such resources are new and additional. Further, the BR guidelines applicable to Annex II Parties require them to provide a description of their national approach for tracking support, information on how the climate support is delivered and through which channels, and a description of the methods and assumptions used (Ellis and Moarif, 2015 ${ }_{[4]}$ ).

62. The CTF tables in BRs are used to report contributions through multilateral channels - whether "core/general" or "climate-specific" 20 (Table 7(a)), through bilateral, regional and other channels (table 7(b)) and a summary of both (Table 7). ${ }^{21}$ For each channel, Parties report finance provided for adaptation, mitigation, crosscutting and other climate change actions. In addition, Parties can report the provision of "core/general" public financial support to multilateral institutions that Parties cannot confirm as being climate-specific. The CTF tables were updated in 2015 through decision 9/CP.21 (UNFCCC, 2015 $5_{[22]}$ ). The revised tables are to be used for the third round of BRs due in January 2018. The revisions consist of i) allowing the provision of additional information on definitions or methodologies used for reporting; ii) introducing a new reporting field for "activity" under contributions through bilateral, regional and other channels; iii)

\footnotetext{
${ }^{17}$ See footnote 16 for Parties listed in Annex II of the Convention.

${ }^{18}$ Not detailed further - see introduction (section 1) for an explanation of this paper’s scope.

19 Under this article, each Party shall communicate a national inventory of GHG emissions, a general description of steps taken to implement the Convention and any other relevant information.

${ }^{20}$ These terms are not defined in decision 19/CP.18, which states that "Parties should explain in their biennial reports how they define funds as being climate-specific".

${ }^{21}$ The terms "bilateral” and “multilateral” are not defined in Decisions 2/CP.17 and 19/CP.18.
} 
aligning the categorisation for the reporting parameter "status" ("pledged", "committed" and "provided") with what is used in other international methodologies ("committed" and “disbursed”) (UNFCCC, 2017 [23] $)$.

63. There are two main lessons learnt from the experience with these arrangements. The first lesson is that by definition, the picture of climate finance provided reported to the UNFCCC is incomplete under the Cancún arrangements due to the scope of Parties with reporting obligations (Caruso and Ellis, 2013 $3_{[24]}$; Ellis and Moarif, 2015[4]). The commitment entered into in Cancún relates to climate finance provision by "developed countries", but developed countries outside Annex II are not required by UNFCCC provisions to report such information. However, in practice, several other countries voluntarily report on their provision of financial resources to developing country Parties. To date, eleven Annex I countries outside the Annex II group of countries have reported on support provided to the UNFCCC, even though they were not required to do so. ${ }^{22}$ In addition, three non-Annex I countries indicated in their BUR that they provide bilateral climate support, with Korea even quantifying the finance provided (Ellis and Moarif, $\left.2016_{[2]}\right) .{ }^{23}$

64. The second lesson is that, despite efforts to improve on reporting through for instance the update of CTF tables, the information reported on finance provided is still inconsistent across Parties in terms of definitions used, level of granularity and methodological transparency. As noted by the Standing Committee on Finance (SCF), the current BR guidelines have a built-in flexibility designed to accommodate a variety of reporting approaches, but in some cases, limited clarity with regard to these approaches limits comparability in climate finance reporting. Despite important improvements in the clarity and granularity of information provided between the first round of BRs (BR1) and the second round (BR2), a review of BR2 shows the extent of the diversity of approaches adopted by Parties.

65. There is a divergence among Annex II Parties' approaches to account for their contributions provided through multilateral channels, increasing the risk of inconsistent information and double-counting. Some Parties, such as Spain, only report their contributions to climate-specific funds such as the Green Climate Fund. Others also report the contributions made to multilateral development banks (MDBs) or other financial institutions and specialised United Nations bodies. In the latter case, countries either account for the totality of their contributions (under a "core/general" column), such as Belgium and Sweden, or apply a coefficient to estimate the proportion of their contribution that has funded climate-specific projects. These coefficients can be drawn from the OECD Development Assistance Committee (DAC) imputed multilateral contribution methodology, ${ }^{24}$ based on the data MDBs report to the DAC (see next section). The imputed multilateral contribution differs in some cases from the climate

\footnotetext{
${ }^{22}$ See the biennial reports of Croatia (2015), Czech Republic (2014, 2016), Estonia (2015), Latvia (2014, 2016), Lithuania (2014, 2016), Malta (2014, 2016), Monaco (2014, 2016), Poland (2013, 2016), Russian Federation (2015), Slovakia (2014, 2015), Slovenia (2014, 2016).

23 See the first biennial update reports (BUR) of Israel (2016), Republic of Korea (2014) and Singapore (2014), as well as Singapore's second BUR (2016).

${ }^{24}$ The climate-specific share of core contribution to multilateral financial institutions is calculated by multiplying the climate-related share of the portfolio for a multilateral financial institution by the un-earmarked contributions from a country to that institution.
} 
finance "ratios" of outflows estimated by the MDBs themselves (ADB, Asian Development Bank; AfDB, African Development Bank; EIB, European Investment Bank; EBRD, European Bank for Reconstruction and Development; IDB, InterAmerican Development Bank; WB, World Bank, 2016 $\left.6_{[25]}\right)$, as the DAC only considers the sub-set of MDB projects located in official development assistance (ODA)-eligible countries in its calculation. Several Parties' BRs do not contain explanations as to how they estimate their "climate-specific" contribution from multilateral channels.

66. Despite nearly all Annex II Parties providing some level of granular information in their BRs, there are still issues with reporting on bilateral finance. The diverse coverage and approaches adopted by Parties makes it more difficult to compare the information provided, or to robustly estimate how much a recipient country has received from several donors. A recent survey ${ }^{25}$ of 27 donor countries and the European

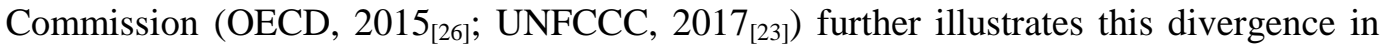
approaches across numerous parameters and key issues with respect to clarity (Table 6).

Table 6. Diversity of approaches and key issues with reporting on bilateral finance in the second round of biennial reports

\begin{tabular}{|c|c|}
\hline Parameter & Issues \\
\hline Recipient country/ region/ project/ programme & $\begin{array}{l}\text { - } \quad \text { Twelve donors provide activity-level data; the rest provide aggregate data. } \\
\text { - Some entries do not have any specific information (e.g. "worldwide", "global", "bilateral } \\
\text { non-allocated", "unspecified" and "other"), and others provide information at } \\
\text { regional/continent level only. }\end{array}$ \\
\hline Climate-specific $^{1}$ & - Most Parties include an explanation, although to varying degrees of detail. \\
\hline Currency (domestic currency and USD) & $\begin{array}{l}\text { - Some Parties reporting only in domestic currencies or not indicating the source for its } \\
\text { exchange rates. }\end{array}$ \\
\hline Status (provided, committed, pledged) & $\begin{array}{l}\text { - Eight donors measure the amounts at point of commitment, three at the point of } \\
\text { commitment and provision (generally depending on the financial instrument they report), } \\
\text { and the rest only at point of provision. } \\
\text { - Few countries define all three terms; for some, provision equals disbursement. }\end{array}$ \\
\hline Funding source (ODA, OOF, other) & $\begin{array}{l}\text { - Thirteen donors include data on other official flows (such as export credits and non- } \\
\text { concessional loans), in addition to official development assistance (ODA). } \\
\text { - Lack of specification of what "other" refers to among six Parties" reports. }\end{array}$ \\
\hline $\begin{array}{l}\text { Financial instrument (grant, concessional } \\
\text { loan, non-concessional loan, equity, other) }\end{array}$ & $\begin{array}{l}\text { - Varying definitions (e.g. "equity", "loan guarantee", "interest subsidy", "capital } \\
\text { subscription", "export credit pure cover", "returned money") or lack of specification of } \\
\text { what "other" refers to. }\end{array}$ \\
\hline $\begin{array}{l}\text { Sector (energy, transport, industry, } \\
\text { agriculture, forestry, water and sanitation, } \\
\text { cross-cutting, other) }\end{array}$ & $\begin{array}{l}\text { - Information on sectoral distribution not always available. Varying definitions (e.g. } \\
\text { "infrastructure", "environmental protection", "capacity-building") or lack of specification of } \\
\text { what "other" refers to. }\end{array}$ \\
\hline Period considered & $\begin{array}{l}\text { - Three donors provide data on a fiscal year basis, while the rest are on a calendar year } \\
\text { basis; }\end{array}$ \\
\hline
\end{tabular}

Note: ${ }^{1:}$ See footnote 24 .

Source: Adapted from (UNFCCC, 2017 ${ }_{[23]}$ ) following authors' review of second round BRs.

25 The OECD (2015) report is based on responses to an OECD survey of Parties' expected UNFCCC reporting as part the second round of biennial reports (BR2). Authors' review of BR2's CTF tables shows that the report (Annex $\mathrm{C}$ in particular), although published prior to BR2 reports, contains at least as much, and sometimes more information regarding methodologies than what is provided in BR2s by Annex II Parties. 
67. Contributions through bilateral channels represented $90 \%{ }^{26}$ of the flows reported in BRs in 2013 and 2014 according to the second biennial assessment and overview of climate finance flows (UNFCCC Standing Committee on Finance, 2016 ${ }_{[27]}$ ). Given their prominence in Parties' reports, particularly while reporting on climate finance mobilised remains voluntary for all Parties and focuses on bilateral rather than multilateral contributions, the lack of comparability between finance provided through bilateral channels is all the more problematic.

\subsubsection{Reporting arrangements outside the UNFCCC}

68. The vast majority of Annex II Parties base the information reported in their BRs on what they routinely communicate to the OECD DAC to inform the comprehensive database of development assistance projects, known as the Creditor Reporting System (CRS). This publicly-available database's main value with respect to the information currently reported to the UNFCCC lies in the fact that it contains activity-level data on both bilateral and multilateral climate-related development finance. The CRS database relies on a statistical system with standardised definitions. It features climate finance information from 30 DAC member countries as well as 15 countries providing information on a voluntary basis, including nine Annex I ${ }^{27}$ and six non-Annex I Parties, ${ }^{28}$ and major MDBs and climate funds. All DAC member countries and three countries that report voluntarily (Lithuania, Romania, and United Arab Emirates) provide information on finance provided through multilateral and bilateral channels.

Countries reporting to the CRS use Rio Markers to indicate whether, in their view, development assistance projects target climate change adaptation and mitigation as a "principal" or "significant" objective, and report the total value of the projects with climate change objectives. ${ }^{29}$ Many DAC members use this information as a basis for their reporting to the UNFCCC, and decide which proportion of the climate finance to report as bilateral finance in their BRs. Most DAC members account for the totality of the development assistance projects where climate change is a "principal" objective, but use different coefficients for projects where climate change is a "significant" objective, while some countries apply project-specific coefficients regardless of the principal/significant distinction (Table 7).

\footnotetext{
${ }^{26}$ The finance reported is mostly spent in grants (35\%), equity and other instruments (35\%), followed by concessional loans (20\%) and non-concessional loans (10\%).

${ }^{27}$ Bulgaria, Cyprus, Estonia, Latvia, Lithuania, Malta, Romania, Russia, Turkey.

${ }^{28}$ Azerbaijan, Israel, Kazakhstan, Kuwait, Thailand, United Arab Emirates.

${ }^{29}$ Activities scored "principal” would not have been funded but for that policy objective; activities scored "significant" have other prime objectives but have been formulated or adjusted to help meet the policy objective.
} 
Table 7. Use of Rio Markers in the reporting of bilateral finance in biennial reports

\begin{tabular}{c|c|l}
\hline $\begin{array}{c}\text { Coefficient on Rio } \\
\text { Marker "principal" }\end{array}$ & $\begin{array}{c}\text { Coefficient on Rio } \\
\text { Marker "significant" }\end{array}$ & \multicolumn{1}{c}{ Countries } \\
\hline $100 \%$ & $100 \%$ & $\begin{array}{l}\text { Czech Republic, Greece, Iceland, Japan, Luxembourg, Norway, } \\
\text { Poland, Slovak Republic, Slovenia }\end{array}$ \\
\hline $100 \%$ & $50 \%$ & Austria, Denmark, Germany, Ireland \\
\hline $100 \%$ & $40 \%$ & EU institutions, France, Italy, Netherlands, Sweden \\
\hline $100 \%$ & $30 \%$ & Australiaa, New Zealanda \\
\hline $100 \%$ & $20-40 \%$ & Spainb \\
\hline $100 \%$ & $0 \%$ & Portugal \\
\hline $100 \%$ & Most relevant & Canadac \\
\hline $51-100 \%$ & $1-50 \%$ & Switzerland \\
\hline Range of coefficients & Range of coefficients & Belgium, Finland \\
\hline n/a & n/a & United Kingdom , United States ${ }^{\mathrm{d}}$ \\
\hline
\end{tabular}

Notes: a : Activity-level coefficients used when feasible, where not, a $30 \%$ coefficient is applied. ${ }^{\text {b: }}$ Activities targeting mitigation or adaptation only are accounted as $20 \%$, activities targeting both as a significant objective are accounted as $40 \%$. ". "Significant" activities screened and most climate-relevant are counted. ${ }^{\text {d: }}$ Uses own approach.

Source: Adapted from (OECD, 2015 $\left.{ }_{[26]}\right)$.

69. Recognising that many countries use the DAC CRS as a basis for reporting bilateral contributions under the UNFCCC, the DAC is working to enhance transparency between Rio marker data and finance flows reported to the Conventions, by proposing the introduction of new data items in the database (OECD, 2017 $\left.{ }_{[28]}\right)$. These items include the measurement basis for reporting the activity to the UNFCCC (commitment, disbursement, other), and the share of the activity reported as mitigation/adaptation/crosscutting to the UNFCCC as a percentage.

70. Conversely, the common principles for tracking mitigation and adaptation activities developed by MDBs together with the International Development Finance Club (World Bank, 2017 [29] ) allow them to track climate finance in a granular manner (although international reporting is done at an aggregate level only). This means that the aggregate levels of climate finance reported by the MDBs covers only those components or proportions of projects that directly contribute to adaptation and/or mitigation.

71. In providing views on accounting for finance provided by public sources (UNFCCC, 2016 [30]), Parties or groups of Parties such as AOSIS noted concerns regarding overreliance on the OECD DAC system which was neither designed for tracking nor for accounting purposes of climate finance under the UNFCCC. Indeed, the OECD DAC's use of the Rio Markers was originally intended to provide a qualitative indication of the degree of mainstreaming of Rio Convention objectives into development co-operation. Key differences between how DAC members account for climate-related finance in the CRS and what they report as climate finance to the UNFCCC relate to varying scopes of eligibility, or the diversity of approaches used, with regards to e.g.:

Diversity of coefficients applied to projects with "principal" and "significant" climate objectives (Table 7);

- Financial instruments, e.g. some countries including export credits in UNFCCC reports, which are not eligible for inclusion under the CRS; 
- Recipients, as the list of eligible non-Annex I countries under the UNFCCC is larger than ODA-eligible countries included under the CRS (see Annex B in (OECD, $\left.2015_{[26]}\right)$.

72. Another point to note regarding the CRS is that reporting focuses mainly on what is defined as concessional finance ${ }^{30}$ (grants and loans). The CRS also hosts information regarding non-concessional finance, but reporting is not compulsory for DAC members. The DAC is working to address this limitation, including through the development of a new international statistical standard: the Total Official Support for Sustainable Development (TOSSD). Aimed at tracking resources invested to achieve the Sustainable Development Goals (SDGs), TOSSD could be applied to climate-specific finance by providing disaggregated information for the climate action goal (SDG 13). TOSSD aims to cover all flows regardless of the financial instrument used, the level of concessionality, or whether they are delivered through bilateral or multilateral channels.

73. Beyond the DAC database, the International Aid Transparency Initiative (IATI) is a distinct format and framework for publishing data, also originally developed to track development co-operation activities. The standard codes and classifications under the IATI standard are largely aligned with the OECD DAC statistical system, but allow for the provision of information on e.g. other sector classifications such as Sustainable Development Goals, or markers defined by the reporting entity. It gathers data from 525 sources, including bilateral and multilateral organisations, development finance institutions, non-governmental organisations and private development assistance providers, including many that do not work on climate. More crucially, very few activities in the database have been tagged as climate-relevant. This means database users interested in climate-related projects have to review all individual projects, thus limiting the usefulness of its dataset for now (Ellis and Moarif, 2016 $6_{[2]}$ ). Countries such as Bangladesh, the Netherlands and Sweden are exploring new ways to use IATI in order to increase transparency and facilitate reporting on climate-related projects (e.g. use of Riomarkers in IATI reporting, disaggregation of data by modality, region and sector, or based on programme-specific data).

\subsection{Finance mobilised through public interventions}

\subsubsection{Key lessons from current reporting experience}

74. The current reporting framework places a non-mandatory request on Annex II Parties to report information on private finance mobilised by bilateral public finance, as well as on policies and measures that promote the scaling up of private investment "to the extent possible" in their biennial reports (UNFCCC, 2011 [20] $)$. Unlike for finance provided, Parties are not requested to report finance mobilised in their NCs.

75. In practice, there is limited experience to date among Annex II countries on reporting private finance mobilised as this information is not routinely tracked. The UNFCCC guidelines for Annex I BRs and the associated CTF tables do not even explicitly request reporting of private finance mobilised via bilateral or multilateral climate finance (Ellis and Moarif, 2016 ${ }_{[2]}$ ). Ten Parties have included some information on private finance mobilised in their second BRs, ranging from qualitative examples (e.g.

\footnotetext{
30 The OECD DAC defines the concessionality level as a measure of the "softness" of a credit reflecting the benefit to the borrower compared to a loan at market rate (see grant element).
} 
Norway, United Kingdom), indicative estimates (e.g. Finland, Japan), to more detailed, partial quantification based on pilot studies (e.g. France). Of these Parties, most included private finance associated with reported bilateral climate finance and, in some instances, with specific funds embedded in multilateral financial institutions (e.g. Canada) (UNFCCC, 2017 $\left.{ }_{[12]}\right)$. Very few countries provided detailed information on their estimation methods and underlying assumptions; France and Sweden were the exceptions. An additional seven Parties indicate their interest in further developing methodologies, or explicitly state their plans to report on finance mobilised in the third round of BRs due in 2018, such as Belgium and the Netherlands.

\subsubsection{Reporting arrangements outside the UNFCCC}

76. Outside the UNFCCC, there are a number of initiatives aimed at improving the ability to measure and report publicly-mobilised private finance. These include work under the OECD-led Research Collaborative on Tracking Private Climate Finance, work by the DAC to measure the volume of private finance mobilised by official development finance interventions, as well as joint work by MDBs. As illustrated in the framework of decision points developed under the Research Collaborative (Jachnik, Caruso and Srivastava, $2015_{[31]}$ ), a number of methodological and definitional considerations must be addressed in order to improve estimations of publicly-mobilised private finance. These include in relation to accounting boundaries, causality assumptions (i.e. how to ensure a focus on private finance that would not have happened in the absence of public intervention), and attribution methods (i.e. in the case of multiple public sources of funding, how to allocate the finance mobilised pro rata based on the role, risk and/or amounts provided or guaranteed by each public actor).

77. Some developed country Parties have undertaken pilot studies to estimate private climate finance they have mobilised, predominantly through bilateral channels. These include Belgium, Denmark, France, Germany and Norway (Van der Laan et al., 2015 [32]; Mostert, Bolscher and Veenstra, 2015 [33]; Abeille et al., 2015 ${ }_{[34]}$; Kempa and Moslener, 2016 ${ }_{[35]}$; Torvanger, Narbel and Francke Lund, 2015 ${ }_{[36]}$ ). Some developing countries have also attempted to estimate how much climate finance has been mobilised from a variety of sources in their countries. For example, pilot studies have been conducted most notably for South Africa (McNicoll et al., 2017 $7_{[37]}$ ), but also in Chile (García, 2016 ${ }_{[38]}$; UNDP, 2017[39] $)$, Ecuador, Thailand, Vietnam and Indonesia (UNDP, 2017[39]).

78. These studies were informed by the work conducted on methodological options and data collection for measuring publicly mobilised private finance by the Research Collaborative as well as the DAC. The Research Collaborative has done work at countrylevel through pilot studies, as well as at an aggregate level (OECD, 2015 ${ }_{[26]}$ ), whereas the DAC focuses on instrument-specific approaches. The DAC has developed and piloted methodologies for five types of official development finance interventions. ${ }^{31}$ These methodologies build on the principles of causality and attribution as defined above. Referring to the work of the Research Collaborative and the DAC, in 201518 developed

\footnotetext{
${ }^{31}$ Guarantees, syndicated loans, equity shares in collective investment vehicles, credit lines and direct investments in companies.
} 
countries $^{32}$ stated to have reached a common understanding of mobilised climate finance, including private finance for climate-relevant activities that has been mobilised by public finance or by a public policy intervention (UNFCCC, 2015 ${ }_{[40]}$ ). This approach informed the OECD estimates of climate finance in 2013-14 and progress made towards the USD 100 billion goal (OECD, 2015 $\left.{ }_{[26]}\right)$.

79. The MDBs have also developed a methodology for tracking climate co-finance. The MDBs define climate co-finance as the amount of financial resources contributed by external (i.e. non-MDB) entities alongside climate finance committed by MDBs, without implying causal relationships (ADB, Asian Development Bank; AfDB, African Development Bank; EIB, European Investment Bank; EBRD, European Bank for Reconstruction and Development; IDB, Inter-American Development Bank; WB, World Bank, 2016 $\left.{ }_{[25]}\right)$. The MDB methodology is now integrated into MDBs' broader efforts to measure private finance mobilisation across their portfolios (World Bank, 2017 [29]; World Bank, 2017 $\left.{ }_{[41]}\right)$. Under this approach, private co-finance is fully attributed to MDBs (disregarding the mobilisation role of other public actors, whether bilateral or domestic), and therefore results in an overestimate of private finance mobilised by MDBs. ${ }^{33}$ The MDBs have capitalisation and shareholding from both developed and developing countries. MDB estimates of climate finance co-finance are also presented at an aggregate level, including for developed countries (World Bank, 2017 ${ }_{[41]}$ ). As such, if estimates of mobilisation by MDBs were to be combined with estimates of mobilisation by other public actors (e.g. bilateral) then this would lead to double counting of private finance mobilised for developing countries.

80. Work is also being undertaken to develop methodologies to estimate the effect of policy-related and capacity-building interventions on private finance, for both domestically-led and international interventions (McNicoll et al., 2017 [37]; Green and Westphal, 2017 ${ }_{[42]}$; Brown and Wang, 2015 $5_{[43]}$; Haščič et al., 2015 $\left.5_{[44]}\right]$. However, quantifying the effect of such interventions is challenging since they often occur upstream from project-level private investment (Brown and Wang, 2015 [43] $_{\text {), and }}$ typically have an effect on private finance over a number of years, and for a number of projects. A major challenge here remains the difficulty to ensure coherent accounting boundaries and information availability across actors so as to avoid double-counting.

\subsection{Proposing an enhanced finance reporting system for developed countries and “other" Parties}

81. Despite recent improvements, there is scope to enhance the reporting of climate finance provided and mobilised under the Paris Agreement when compared to existing reporting arrangements. Examples include systematically providing more granular information at the project-level, and ensuring increased convergence of approaches, classifications and definitions across reporting countries. Views submitted by Parties and observers (UNFCCC, 2017 ${ }_{[23]}$ ), and recommendations from the Standing Committee on

32 Australia, Belgium, Canada, Denmark, Finland, France, Germany, Italy, Japan, Luxembourg, Netherlands, New Zealand, Norway, Poland, Sweden, Switzerland, United Kingdom, United States, and the European Commission.

33 The MDB methodology is intended to capture private finance mobilised for developing countries, but also covers some developed countries (World Bank, 2017 [29]). 
Finance (UNFCCC Standing Committee on Finance, 2016 ${ }_{[27]}$ ) highlight that lack of clarity on different approaches to defining climate finance negatively impacts data comparability, for example. Uncertainties arise from differences in the way that countries classify data as climate finance. The revised CTF to be used in the third round of biennial reports under the UNFCCC (due on January 1 2018) partly addresses these issues for the purposes of the existing reporting regime, as it clarifies reporting options and specifies which terms reporting Parties need to define. Assessing how consistently Annex II Parties use the revised CTF in 2018 may inform the need to further revise those tables for the purposes of the Paris Agreement's enhanced transparency framework, for instance by specifying suggested common sources and references. Qualifiers related to the Paris Agreement, such as the need for financial resources to be "scaled up" (Art. 9.4), or for mobilisation to represent "a progression beyond previous efforts" (Art. 9.3) (Briner and Moarif, 2016[1]) may also be required.

82. The Paris Agreement's provisions mandate addressing two additional gaps in particular. These gaps are the lack of experience in reporting private finance mobilised to date and the possibility to accommodate new reporting Parties. The design of MPGs for the reporting of finance provided and mobilised thus offers opportunities for enhanced transparency in those areas. However, the current draft "headings and subheadings" of the MPGs as set out in the Annex to the APA informal note focus on increased reporting of climate finance mobilised bilaterally, rather than multilaterally (APA, 2017 $[11]$ ). Such headings are therefore potentially limiting depending on how Parties take them forward.

83. Four suggestions for how Parties might address these two additional, mandated gaps are mapped out against the APA informal note outline (APA, 2017 ${ }_{[11]}$ ) in Table 8, and further detailed below:

1. Integrating the reporting of private finance mobilised through public interventions into CTF reporting, for example by revising existing table 7(b) or creating a new CTF table 7(c);

2. Encouraging activity-level reporting from multilateral public finance providers to the UNFCCC on public finance provided and private finance mobilised through multilateral channels, with the aim of increasing consistency and avoiding doublecounting.

3. Encouraging “other Parties” to build on Annex II Parties' experience by using the most up-to-date reporting tables, and start collecting and reporting data for the categories for which they are missing information. Parties could also consider including enhanced reporting of climate finance provided and mobilised as part of improvement plans; ${ }^{34}$

4. Allowing more flexible reporting tools, or creating an online interface enabling data export and personalised searches, to make the reporting of information less time-consuming and the information more accessible to developing country Parties. The OECD DAC's “Query Wizard for International Development Statistics" (QWIDS) database could serve as an example. The QWIDS facilitates the search and extraction of project-level data on resource flows to developing countries including from the CRS.

\footnotetext{
34 The outline in the APA informal note currently refers to improvements plans in the section on national inventory reports only (APA, 2017 $[11]$ ).
} 
Table 8. Comments and suggestions on APA informal note outline: finance provided and mobilised

\begin{tabular}{|c|c|}
\hline Headings & Comments and suggestions \\
\hline 1. Objectives and principles & To be revised to reflect the shift to developed countries/ other Parties providing support \\
\hline $\begin{array}{l}\text { 2. National circumstances and institutional } \\
\text { arrangements including a) Plans and strategies }\end{array}$ & $\begin{array}{l}\text { Could include criteria used to determine priority recipients; enabling policies to promote finance; } \\
\text { information on how developing country Parties' needs are taken into account.* }\end{array}$ \\
\hline $\begin{array}{l}\text { 3. Underlying assumptions, definitions, and } \\
\text { methodologies }\end{array}$ & $\begin{array}{l}\text { Could include information to ensure no double counting, definitions of terms such as "scaling- } \\
\text { up" and "progression beyond previous efforts". } \\
\text { Could include information related to items listed in the documentation box in revised CTF tables } \\
\text { (2015), and consider adding "objectives", "descriptive information" and "timeframe".* }\end{array}$ \\
\hline $\begin{array}{l}\text { 4. b) Information on financial support mobilised } \\
\text { by developed country Parties }\end{array}$ & $\begin{array}{l}\text { Consider sourcing information on finance mobilised through multilateral channels from a third } \\
\text { party, e.g. the OECD DAC (which currently has data on mobilisation via five financial } \\
\text { instruments from MDBs, see paragraph 87), or encourage multilateral financial institutions to } \\
\text { submit such data at a disaggregated level to the UNFCCC. } \\
\text { See suggested } \\
\text { Table } 9 \text { regarding possible CTF reporting to account for private finance mobilised by public } \\
\text { interventions }\end{array}$ \\
\hline $\begin{array}{l}\text { 5. a) Information on financial support provided } \\
\text { by other Parties }\end{array}$ & $\begin{array}{l}\text { Consider encouraging "other Parties" to build on Annex II Parties' experience to date through } \\
\text { use of up-to-date reporting tables, data collection for categories with missing information etc }\end{array}$ \\
\hline $\begin{array}{l}\text { b. b) Information on financial support mobilised } \\
\text { by other Parties }\end{array}$ & As above \\
\hline 10. Reporting format & $\begin{array}{l}\text { Could refer to the creation of more flexible reporting tools or an online interface enabling } \\
\text { data export and personalised searches }\end{array}$ \\
\hline
\end{tabular}

Note: This table draws from the headings under "Information on financial, technology transfer and capacitybuilding support provided under Articles 9-11 of the Paris Agreement”. *: As per items listed in APA 2017.

Source: (APA, 2017 $[11]$ ).

84. Firstly, including reporting on private finance mobilised through bilateral channels into CTF reporting would help to improve consistency and comparability in reported information, methodological transparency, and avoid double-counting, building on current efforts by the international community to collect data and develop methodologies (see section 4.2.2 (UNFCCC, 2015 $\left.{ }_{[40]}\right)$ ).

85. Table 9 suggests what CTF elements for reporting finance provided and mobilised through public bilateral, regional and other channels could look like. Adapting existing CTF table 7(b) or creating a new table 7(c) are two potential options.

86. Secondly, the Conference of Parties could consider encouraging multilateral public finance providers, such as climate funds and MDBs, to voluntarily report to the UNFCCC on contributions and finance mobilised at the activity level. This could facilitate improved consistency of reporting of finance provided and mobilised through multilateral channels, including to inform the global stocktake. Such disaggregated reporting would, in particular, allow for data users to include or exclude specific recipient countries depending on different eligibility criteria, as well as make it possible to avoid double counting of private finance mobilised by multilateral and bilateral actors respectively. It could build on the emerging experience of collective reporting of mobilised climate finance to date (OECD, 2015 ${ }_{[26]}$ ) and a growing methodological body of work (see section 4.2.2). A third-party, such as the UNFCCC Secretariat, could perform quality control and harmonisation of data to ensure consistent and transparent criteria are used for "climate-specific" contributions, recipient countries, and consistent attribution methods between Parties. Such voluntary reporting could follow a similar template to that proposed for contributions through bilateral channels, and could potentially replace Parties' reporting of financial contributions to multilateral channels over time. The voluntary reporting of information from non-Party stakeholders has 
already been suggested as a way to ensure consistent assessments of private finance collectively mobilised through multilateral channels, and avoidance of double counting (Ellis and Moarif, 2016 ${ }_{[2]}$ ).

87. As mentioned in section 4.1.1, Annex II countries use a variety of definitions to account for their climate-specific contributions to multilateral channels, or inflows, or do not explain how they are accounted. Certain Parties report total contributions to multilateral institutions, rather than climate-specific funds. MDBs either only report on aggregate amounts of finance provided, i.e. on their outflows, in their joint annual report (ADB, Asian Development Bank; AfDB, African Development Bank; EIB, European Investment Bank; EBRD, European Bank for Reconstruction and Development; IDB, Inter-American Development Bank; WB, World Bank, 2016 ${ }_{[25]}$, then reported in the SCF's Biennial Assessment, or report at the activity-level to the OECD DAC. To avoid duplication of reporting, Parties could consider sourcing this information from the OECD DAC, which, in addition to bilateral finance, collects data on both inflows to and outflows from multilateral institutions, as well as on private finance mobilised by these institutions. The DAC has to date collected data on amounts mobilised through five financial instruments used by the MDBs, ${ }^{35}$ and is expected to propose methodologies for inclusion of amounts mobilised by a broader range of instruments ${ }^{36}$ in the Committee's regular reporting from 2019, for 2018 data. In addition, the DAC is proposing the introduction of further data items to enhance the level of transparency between the data its members report to the CRS and that reported to the UNFCCC, as outlined in section 4.1.2.

88. Thirdly, the common set of MPGs would be applicable to both developed and other Parties providing support, acknowledging that reporting is a mandatory requirement for the former, and a voluntary request for the latter. To ensure the information reported by both sets of Parties is consistent with existing practices, "other Parties" could aim to use the most up-to-date reporting tables revised in 2015 (Decision 9/CP.21) in the future, and start collecting data for the categories for which they are missing information. Although other Parties providing support are only "encouraged" to communicate this information, the scope of Parties reporting is likely to widen over time. The climate finance flows between developing countries are significant, and were estimated at USD 10 billion in 2013 (Buchner et al., 2014 ${ }_{[45]}$ ) in (Ellis and Moarif, 2016 $6_{[2]]}$ ). Figure 3 illustrates the various groupings that could be used as indicative references to identify potential reporting Parties. ${ }^{37}$

89. Finally, in submitting their views on accounting for finance, some Parties ${ }^{38}$ noted that the current reporting format (report and accompanying spreadsheets converted into PDF documents) was impractical (UNFCCC Standing Committee on Finance, 2016 [27]). An exporting tool, instead of a spreadsheet, would make reporting more efficient and less

\footnotetext{
35 Guarantees, syndicated loans, shares in collective investment vehicles, direct investment in companies and credit lines.

36 For example project finance schemes, standard loans and grants in simple co-financing arrangements.

${ }^{37}$ All EU Member States are required to report on climate finance support to developing countries under the EU Monitoring Mechanism Regulation.

${ }^{38}$ Including Switzerland on behalf of the Environmental Integrity Group.
} 
prone to manual errors in consolidating data. Such a "macro" tool has been developed for the third round of biennial reporting. Its efficacy ought to be assessed before "other Parties" are invited to use it under the Paris Agreement's enhanced transparency framework. From the recipient's perspective, it is also very difficult to use the data on finance provided and mobilised to get an overview of finance flows to a specific country, either by scanning through submitted reports, or through the financial contributions page of the Biennial Report Data Interface (BR-DI). Such a tool could therefore also contain an online interface enabling data export and personalised searches, to allow developing country Parties to use this information in monitoring finance received, for instance. The OECD DAC's QWIDS database also provides an example of an online interface enabling data export.

\section{Figure 3. Potential reporting Parties on finance provided and mobilised (developed country} Parties and other Parties providing support)

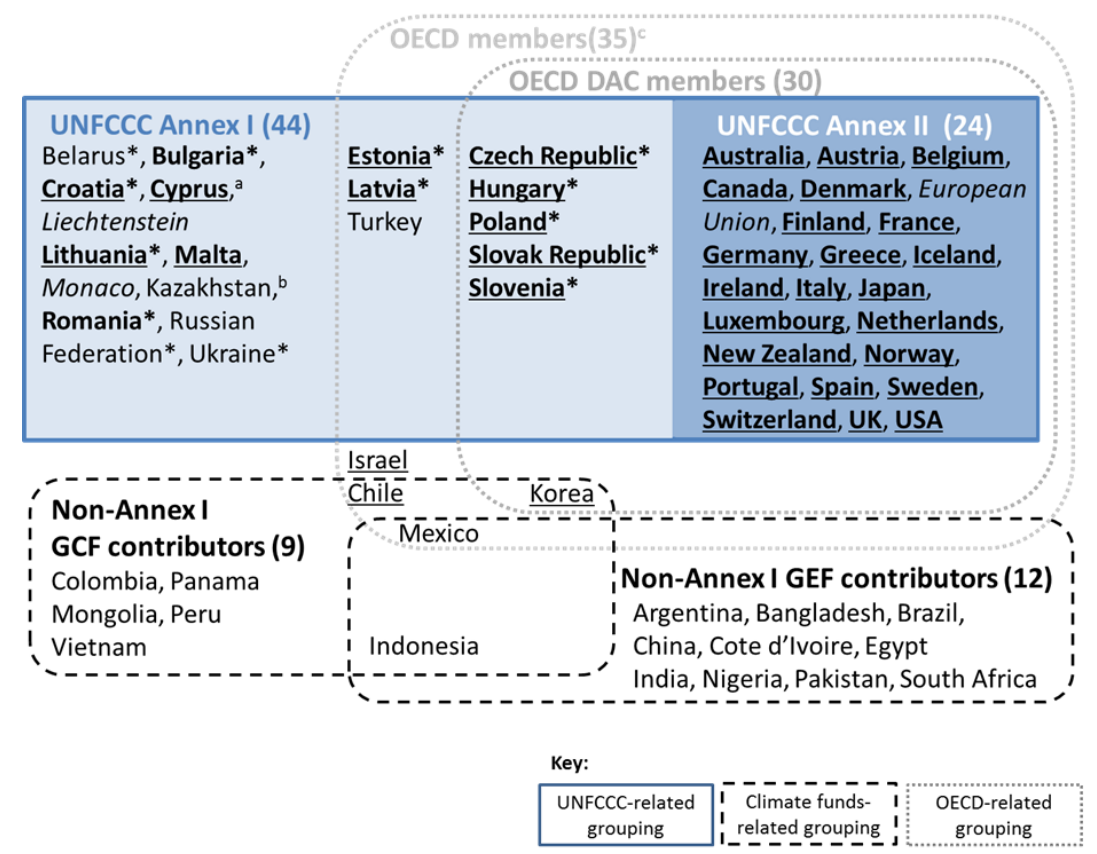

Note: GEF: Global Environment Facility; GCF: Green Climate Fund

Developed economies (including EU members since 2004) according to the UN World Economic Situation and Prospects 2017 (UN WESP), excluding regional organisations or countries not listed;

High-income economies by per capita GNI in 2016 (excluding fuel-exporting countries and SIDS) according to the UN WESP 2017;

*: Economy In Transition (EIT) under the UNFCCC;

a: Note by Turkey- The information in this document with reference to "Cyprus" relates to the southern part of the Island. There is no single authority representing both Turkish and Greek Cypriot people on the Island. Turkey recognises the Turkish Republic of Northern Cyprus (TRNC). Until a lasting and equitable solution is found within the context of the United Nations, Turkey shall preserve its position concerning the "Cyprus issue". Note by all the European Union Member States of the OECD and the European Union- The Republic of Cyprus is recognised by all members of the United Nations with the exception of Turkey. The information in this document relates to the area under the effective control of the Government of the Republic of Cyprus. b: Kazakhstan is included in Annex I for purposes of the Kyoto Protocol (although not for the Convention), and submitted its third national communications and second biennial report following Annex I guidelines.

c: The European Union is not formally a member of the OECD. 
Table 9. Potential CTF table elements to account for private finance mobilised by public interventions

Illustrative option 1: adapting CTF Table 7(b) adopted through decision 9/CP.21 (revisions effected by decision 9/CP.21in bold, authors' suggested additions to account for private finance mobilised highlighted).

\begin{tabular}{|c|c|c|c|c|c|c|c|c|c|c|}
\hline \multirow{3}{*}{$\begin{array}{c}\text { Recipient } \\
\text { countryl } \\
\text { region/project/ } \\
\text { programme/ } \\
\text { activity }^{b}\end{array}$} & \multirow{2}{*}{\multicolumn{2}{|c|}{$\begin{array}{c}\text { Total amount of } \\
\text { Party's" } \\
\text { contribution }\end{array}$}} & Status ${ }^{c, 3}$ & $\begin{array}{l}\text { Type of public } \\
\text { intervention and } \\
\text { instrument }{ }^{5}\end{array}$ & $\begin{array}{l}\text { Type of } \\
\text { support6 }\end{array}$ & Sectord, 7 & \multirow{2}{*}{\multicolumn{2}{|c|}{$\begin{array}{c}\begin{array}{c}\text { Total amount of } \\
\text { private finance } \\
\text { mobilised }^{8}\end{array} \\
\text { Climate-specific f,2 }^{f, 2}\end{array}$}} & \multirow{3}{*}{$\begin{array}{l}\text { Share of private } \\
\text { finance mobilised } \\
\text { attributed to } \\
\text { Party's } \\
\text { contribution (\%)i,9 }\end{array}$} & \multirow[t]{3}{*}{$\begin{array}{l}\text { Additional } \\
\text { information }\end{array}$} \\
\hline & & & Committed & Grant & Mitigation & Energy & & & & \\
\hline & $\begin{array}{l}\text { Domestic } \\
\text { currency }\end{array}$ & USD & & $\begin{array}{c}\text { loan } \\
\text { Non- } \\
\text { concessional } \\
\text { loan } \\
\text { Equity } \\
\text { Otherg }\end{array}$ & $\begin{array}{l}\text { Cross- } \\
\text { cuttingh } \\
\text { Otherg }\end{array}$ & $\begin{array}{l}\text { Industry } \\
\text { Agriculture } \\
\text { Forestry } \\
\text { Water and } \\
\text { sanitation } \\
\text { Cross-cutting } \\
\text { Otherg }\end{array}$ & $\begin{array}{l}\text { Domestic } \\
\text { currency }\end{array}$ & USD & & \\
\hline
\end{tabular}

Note: Explanation of numerical footnotes is provided in the documentation box after tables 7, 7(a) and 7(b). [2: Climate-specific, 3: Status, 5: Type of public intervention and instrument, 6: Type of support, 7: Sector, 8: Total private finance mobilised, 9: Attribution of mobilised finance].

Abbreviations: USD = United States dollars.

$b$ Parties should report, to the extent possible, on details contained in this table.

c Parties should explain, in their biennial reports, the methodologies used to specify the funds as disbursed and committed. Parties will provide the information for as many status categories as appropriate in the following order of priority: disbursed and committed.

${ }_{d}$ Parties may select several applicable sectors. Parties may report sectoral distribution, as applicable, under "Other".

$e$ Parties should report, as appropriate, on project details and the implementing agency.

${ }_{f}$ Parties should explain in their biennial reports how they define funds as being climate-specific.

${ }_{g}$ Please specify

$h$ This refers to funding for activities that are cross-cutting across mitigation and adaptation.

$i$ Parties are requested to explain in their biennial reports the methodologies used to determine the causal link between a public intervention and private finance. 
Illustrative option 2: creating a new CTF Table 7(c)

\begin{tabular}{|c|c|c|c|}
\hline \multirow{2}{*}{$\begin{array}{c}\text { Recipient country/ } \\
\text { region/project/ } \\
\text { programme/ activity }\end{array}$} & \multicolumn{2}{|c|}{ Total amount of private finance mobilised8 } & Share of private finance mobilised attributed to \\
\cline { 2 - 3 } & Party's contribution (\%), & \multirow{2}{|c|}{ Additional informatione } \\
\cline { 2 - 3 } & Domestic currency & USD & \\
\hline
\end{tabular}

Note: Explanation of numerical footnotes is provided in the documentation box after tables 7, 7(a), 7(b) and 7(c). [2: Climate-specific, 8: Total private finance mobilised, 9: Attribution of mobilised financel.

Abbreviations: United States dollars.

$b$ Parties should report, to the extent possible, on details contained in this table.

$e$ Parties should report, as appropriate, on project details and the implementing agency. $f$ Parties should explain in their biennial reports how they define funds as being climate-specific.

$g$ Please specify.

$h$ This refers to funding for activities that are cross-cutting across mitigation and adaptation.

$i$ Parties are requested to explain in their biennial reports the methodologies used to determine the causal link between a public intervention and private

finance. 


\section{Enhancement of finance reporting - financial support received and needed}

90. The Paris Agreement makes only marginal changes compared to existing reporting arrangements under the UNFCCC with respect to the reporting of finance received and needed. As under existing arrangements, developing country Parties are encouraged to report on the support received and needed under the future enhanced transparency framework (Art. 13.10). Reporting under the framework for transparency of support is to be addressed by the common MPGs to be developed by the APA. The MPGs are to take into account SBSTA's work on methodologies for reporting on financial information, and the aim of enhancing reporting by developing country Parties on support received, including the use, impact and estimated results thereof (Decision 1/CP.21 paragraph 94d). This provision could provide the need for potentially more guidance and technical work than what currently exists on support received (Briner and Moarif, 2016 $[3]$ ).

91. The following sections present, for both financial support received and needed, key lessons from current reporting experience under the Cancún arrangements (sections 5.1.1 and 5.2.1). The analysis draws on lessons from non-Annex I Parties' BURs, and existing monitoring and reporting arrangements domestically, to assess how they could potentially help fill gaps under the Paris Agreement's enhanced transparency framework (see section 5.1.2 and 5.2.2). The last sub-section synthesises what an enhanced reporting system could look like for financial support received and needed by developing countries. It sets out potential steps to more comprehensive reporting of information in line with the requirements of the Paris Agreement, including the Agreement's emphasis on facilitating improvement and implementation (section 5.3).

\subsection{Finance received}

\subsubsection{Key lessons from current reporting experience}

92. Under the UNFCCC, non-Annex I countries are subject to a voluntary request to report on financial resources received in their BURs and their NCs. The reporting guidelines for BURs state that non-Annex I Parties "should" report information on financial resources received by the GEF, the GCF, and other multilateral institutions, as well as Annex II and other developed country Parties (Annex III of Decision 2/CP.17). The consultative group of experts (CGE) developed tables for reporting on this information from multilateral and bilateral sources. Within each category, support is to be listed according to finance, capacity building, technology support and technology transfer, without any further guidance regarding what information to report.

93. Between December 2014 and September 2017, 38 non-Annex I Parties (24\%) submitted at least one BUR, and 9 submitted two (Andorra, Argentina, Bosnia and Herzegovina, Brazil, Chile, Lebanon, Namibia, Singapore and Tunisia). Of the 38 BURs submitted in the first round of reporting, 23 contained summary information on finance received over a specified period of time, and 13 provided information per project or activity in a tabular format (authors' update of UNFCCC Standing Committee on Finance, 2016). Most Parties adapted the tables provided by the CGE to match their own country circumstances and needs. 
94. The key lessons from reporting of finance received to date are:

- Overall, non-Annex I Parties have considerably less experience in reporting on climate finance under the UNFCCC than Annex II Parties. Just over half of the nonAnnex I countries that submitted BURs reported information on finance received, but overall these represent only a small subset of developing countries.

- Among the Parties that have reported on finance received, the coverage, definitions and methods for reporting are very different from one Party to another (Table 10).

- The level of detail of financial information provided in BURs varies greatly between Parties. While some Parties (e.g. Brazil and Ghana) include specific tables and detailed summary information on finance received (such as the type of financial instrument, the specific sector or activity, and the proportion of climate-specific finance), a few Parties (e.g. Azerbaijan and Israel) refer to projects that had received financing in generic terms, or do not provide a section on climate finance received at all (e.g. Serbia). Many Parties state challenges in collecting financial information for their BURs.

- Virtually all the reporting on climate finance received focuses on national-level information, without accounting for finance received by local governments or NGOs, or private finance mobilised by public finance contributions - even though such entities can be the direct beneficiaries of climate finance provided or mobilised by developed countries.

- Few countries explain how they derive the figures on finance received in their BURs. For those that do (such as Chile and Colombia), processes specified include compiling information from a range of different agencies or bodies within the national government and drawing on publicly available information from various international sources (e.g. regional development banks or UN bodies) and bilateral climate finance providers.

95. When reporting on finance received, developing countries could potentially use information on finance provided by developed or other countries as a source of information. However, reporting experience to date illuminates several challenges in trying to reconcile flows of climate finance provided with finance received (Ellis and Moarif, 2015 ${ }_{[4]}$ ). Information on finance provided reported to the UNFCCC often cannot be easily disaggregated by recipient country (see section 4.1.1), as Annex II Parties can report on amounts provided at the programme or region level. Developing countries might adopt different definitions in reporting on finance received than Annex II Parties might adopt for finance provided. For example, developing countries may decide to only account for grants received by the central government. Finally, there can be a time-lag between financial commitments, disbursements and receipt, because different time periods are reported, or due to the existence of financial intermediaries. For example, the South African BUR aggregates climate finance received over the 2000-2010 time period (DEA, 2014), whereas Annex II countries report climate finance for biennial (i.e. twoyear) periods in BRs - as will developed countries under the Paris Agreement's enhanced transparency framework.

96. Reporting arrangements outside the UNFCCC (see section 4.1.2) raise similar challenges. The amount of climate finance received reported by individual non-Annex I Parties in their BURs can be very different from amounts reported by donor countries through the OECD DAC's CRS, for example. Although Chile and Indonesia reported receiving amounts of climate finance 20 times smaller than the climate flows accounted for in the CRS, Montenegro and Argentina reported finance received figures 65\% and 
135\% greater than the amounts accounted for in the CRS, for instance (Ellis and Moarif, $2016_{[2]}$.

Table 10. Information on finance received in non-Annex I Parties’ BURs

\begin{tabular}{|c|c|c|}
\hline & Number of BURs providing this information & Illustrations \\
\hline $\begin{array}{l}\text { Clear definition of financial } \\
\text { support received }\end{array}$ & $\begin{array}{l}7 \text { Defined } \\
30 \text { Not defined }\end{array}$ & $\begin{array}{l}\text { India counts financial resources from the GEF and CERs } \\
\text { from CDM projects. Serbia does not include a section on } \\
\text { climate finance received }\end{array}$ \\
\hline $\begin{array}{l}\text { Explanation of data collection } \\
\text { methodology }\end{array}$ & $\begin{array}{l}8 \text { Available } \\
29 \text { No information }\end{array}$ & Chile and Colombia provide clear methodologies. \\
\hline $\begin{array}{l}\text { Coverage of financial } \\
\text { instruments included/ Type of } \\
\text { finance received }\end{array}$ & $\begin{array}{l}15 \text { Grants and loans, } \\
5 \text { Grants only } \\
2 \text { Other definition (e.g. only ODA) } \\
15 \text { No information }\end{array}$ & $\begin{array}{l}\text { Republic of Korea: donation, grant aid, stock \& equity, } \\
\text { stock \& shares. } \\
\text { Peru: Grant, concessional loan (whether ODA or not) }\end{array}$ \\
\hline Status of finance received & $\begin{array}{l}15 \text { Completed, ongoing and approved } \\
2 \text { Other definition } \\
20 \text { No information }\end{array}$ & $\begin{array}{l}\text { Brazil: Reports Approved, Signed and Received finance, } \\
\text { including the date specified for commitment/ receipt } \\
\text { Indonesia: Reports Approved and Disbursed }\end{array}$ \\
\hline $\begin{array}{l}\text { Definition for source of finance } \\
\text { received }\end{array}$ & $\begin{array}{l}24 \text { UN climate funds, regional development banks, } \\
\text { bilateral donors } \\
4 \text { UN Climate Funds } \\
7 \text { No information }\end{array}$ & $\begin{array}{l}\text { India: only counts financial resources from the GEF and } \\
\text { CERs from CDM projects. } \\
\text { Ghana: includes resources from the national budget } \\
\text { (domestic spending) and result-based payments }\end{array}$ \\
\hline $\begin{array}{l}\text { Implementing entity/ Recipient } \\
\text { of finance received }\end{array}$ & $\begin{array}{l}4 \text { National/Central government only } \\
3 \text { Project-level } \\
30 \text { No information }\end{array}$ & $\begin{array}{l}\text { Chile: Specific information for large and private projects } \\
\text { Ghana: Specific information for ministries and } \\
\text { implementing agencies, international NGOs, research \& } \\
\text { university, private partners }\end{array}$ \\
\hline $\begin{array}{l}\text { Type of activity funded } \\
\text { through finance received * }\end{array}$ & $\begin{array}{l}29 \text { Mitigation/adaptation/ both } \\
2 \text { Sector-specific focus } \\
19 \text { Finance for BUR production } \\
3 \text { Finance for BUR production only } \\
4 \text { No information/unclear }\end{array}$ & $\begin{array}{l}\text { Ghana specifies by theme: mitigation, adaption, } \\
\text { means of implementation } \\
\text { Chile reports on whether finance was for } \\
\text { mitigation, adaptation, reporting, national } \\
\text { greenhouse gas inventory, or international } \\
\text { negotiations }\end{array}$ \\
\hline $\begin{array}{l}\text { Project-level activity } \\
\text { information }\end{array}$ & $\begin{array}{l}12 \text { Available } \\
25 \text { No information }\end{array}$ & Brazil: Provision of sector-specific information \\
\hline Currency exchange rate used & $\begin{array}{l}6 \text { Multiple currencies, conversion rate clearly specified } \\
6 \text { Multiple currencies, conversion rate not specified } \\
19 \text { Single currency } \\
6 \text { No information }\end{array}$ & $\begin{array}{l}\text { Brazil: Exchange rate based on OECD annual exchange } \\
\text { rate for year of project commitment }\end{array}$ \\
\hline Time period used & $\begin{array}{l}23 \text { Multi-Annual } \\
14 \text { No information }\end{array}$ & $\begin{array}{l}\text { Paraguay: Between } 1995 \text { and } 2015 . \\
\text { South Africa: Between } 2000 \text { and } 2010\end{array}$ \\
\hline Sources of information used * & $\begin{array}{l}10 \text { Agencies or bodies within the national government } \\
4 \text { Publicly available information from various } \\
\text { international sources (e.g. regional development banks } \\
\text { or UN bodies) } \\
2 \text { Bilateral climate finance providers } \\
27 \text { No information/ unclear }\end{array}$ & $\begin{array}{l}\text { Montenegro: uses data from DAC } \\
\text { Morocco: Ministry of Finance data supplemented by data } \\
\text { from other ministries and public bodies. } \\
\text { Peru: Detailed list of information providers }\end{array}$ \\
\hline
\end{tabular}

Note: Authors' review. *: Many countries provided more than one type of activity or source used.

Source: Non-Annex I countries BURs.

\subsubsection{Reporting arrangements outside the UNFCCC}

97. There is limited public information available on reporting arrangements outside the UNFCCC for climate finance received. Existing studies discuss the monitoring and reporting arrangements of a small number of developing countries in general terms (Bird 
and Granoff, 2016 $\left.{ }_{[46]}\right)$; (Buchner et al., 2012 $\left.{ }_{[47]}\right)$; (Ellis and Moarif, 2016 $\left.{ }_{[2]}\right)$; (Tirpak, Stasio and Tawney, 2012 ${ }_{[48]}$ ) but do not provide detailed information on how countries collect data on international finance received. Similarly, the majority of developing countries rarely describe their financial monitoring systems in detail when reporting on results produced by these systems in documents such as BURs.

98. From the information available, non-Annex I Parties take two main approaches to tracking climate finance received. ${ }^{39}$ The first approach consists of establishing a new purpose-built monitoring system for climate finance (Table 11). The second approach involves building on a country's existing monitoring system for public financial management and adapting it to both include climate-related flows and bring the system closer to reporting requirements under the UNFCCC (Table 17, in Annex). ${ }^{40}$

Table 11. Examples of purpose-built climate change monitoring systems for finance received in non-Annex I Parties

\begin{tabular}{|c|c|c|c|c|}
\hline Country & $\begin{array}{l}\text { Name of system (year of } \\
\text { establishment) }\end{array}$ & $\begin{array}{l}\text { Entity responsible for } \\
\text { monitoring }\end{array}$ & Financial instrument tracked & $\begin{array}{l}\text { Contribution to the information } \\
\text { reported under the UNFCCC } \\
\text { (year of submission) }\end{array}$ \\
\hline Ghana & $\begin{array}{l}\text { Climate Data Hub - } \\
\text { Domestic Electronic } \\
\text { Registry System (DERS) } \\
(2013)\end{array}$ & $\begin{array}{l}\text { The Environmental } \\
\text { Protection Agency (EPA), } \\
\text { under the Ministry of } \\
\text { Environment, Science, } \\
\text { Technology } \\
\text { and Innovation (MESTI) }\end{array}$ & $\begin{array}{l}\text { Public and private finance for grants, } \\
\text { loans and other financial instruments, } \\
\text { i.e. result based payment }\end{array}$ & $\begin{array}{l}\text { Information from the system } \\
\text { used for Ghana's first BUR } \\
\text { (2015) }\end{array}$ \\
\hline Indonesia & $\begin{array}{l}\text { National Registry System } \\
\text { or SRN (2016) }\end{array}$ & $\begin{array}{l}\text { Directorate General of } \\
\text { Climate Change, Ministry of } \\
\text { Environment and Forestry }\end{array}$ & $\begin{array}{l}\text { Designed to report on public and } \\
\text { private finance for grants, } \\
\text { concessional and non-concessional } \\
\text { loans and other financial instruments } \\
\text { e.g. equity and insurance }\end{array}$ & $\begin{array}{l}\text { The system is still in the early } \\
\text { stages of development and has } \\
\text { not yet been used for any } \\
\text { formal reporting to the } \\
\text { UNFCCC }\end{array}$ \\
\hline $\begin{array}{l}\text { South } \\
\text { Africa }\end{array}$ & $\begin{array}{l}\text { Climate Change } \\
\text { Response Monitoring and } \\
\text { Evaluation System and } \\
\text { database (2009) }\end{array}$ & $\begin{array}{l}\text { Department of Environmental } \\
\text { Affairs and National Treasury }\end{array}$ & $\begin{array}{l}\text { Public and private finance for grants, } \\
\text { loans and other financial instruments }\end{array}$ & $\begin{array}{l}\text { Information from the system } \\
\text { used for South Africa's first } \\
\text { BUR (2014) and second NC } \\
\text { (2011) }\end{array}$ \\
\hline
\end{tabular}

Sources: (EPA, 2017 $[49]$ ); (Government of Indonesia, 2017[50]); (Government of South Africa, 2015 ${ }_{[51]}$ ).

99. There can be national benefits to developing a purpose-built monitoring system for climate finance received, including the potential for more consistent data records and lower risk of double counting. The supporting conditions for the establishment of such a system could include either a formal political mandate for data collection or strong partnerships with the stakeholders who own the relevant data. Without a strong mandate to consolidate financial data there is a risk that such systems may provide data of poor quality and remain disconnected from developing country Parties' public financial management.

39 Authors' categorisation based on desk-based research of countries having conducted a Climate Public Expenditures and Institutional Review (UNDP, 2015 ${ }_{[83]}$ ), and interviews with selected developing country officials.

40 Some countries with monitoring systems in place may have not been included due to limited access to relevant information or the unavailability of potential interviewees at the time of writing. 
100. As highlighted in Table 11, Ghana, Indonesia and South Africa are three countries with a purpose-built monitoring system in place. All three countries' systems were launched and operationalised as part of an integrated climate change monitoring system, including climate finance needs, and mitigation and adaptation-related information. Supported by a formal political mandate, an integrated climate change monitoring system has allowed South Africa's Department of Environmental Affairs to consolidate and centrally manage data from multiple agencies since 2009, feeding into its BUR and second NC. South Africa's system also benefits from the existence of the national statistics authority (Stats SA) in consolidating climate finance data provided by different institutions (Boyd et al., 2014 ${ }_{[52]}$ ) (McNicoll et al., 2017[37]). Box 1 explains how South Africa's monitoring system and research collaboration support the country's efforts to track private climate finance.

\section{Box 1. Robust monitoring system of climate finance supports efforts to track private climate finance: the case of South Africa}

South Africa is one of few non-Annex I countries to systematically monitor and track private climate finance. The Department of Environmental Affairs (DEA) leads the implementation of a national monitoring, evaluation and reporting system for mitigation action and loans and grants received from public and private sources, funded by the national budget (the Climate Change Response Monitoring and Evaluation System and database). The DEA is supported by Statistics South Africa (Stats SA), which has been instrumental in consolidating climate finance data from multiple sources.

Stats SA has learned to overcome key challenges in tracking private climate finance, such as collecting information from the private sector, whose data is often confidential (Stadelmann, Michaelowa and Roberts, $2013_{[53]}$ ). This ability to overcome challenges has increased Stats SA's capacity over time, as well as stakeholders' confidence about the reporting of protected financial data. Various government entities at different levels including line ministries, the National Treasury, local government, civil society organisations, and research institutions submit climate finance data to Stats SA for central management.

Although private climate finance data are limited to renewable energy and the energy efficiency sector in South Africa, a review exercise by the DEA has produced some useful findings. South Africa's efforts to track private climate finance show that domestic actors play a significant role in the mobilisation of private climate finance. The actors promote targeted policies and commit to co-financing climate projects. From the limited data available, it appears that capacity-building more broadly has an indirect effect on the mobilisation of private finance over time.

Key factors behind South Africa's efforts in tracking private climate finance are the existing regulatory framework to support Stats SA in consolidating and centrally managing data, the DEA's integrated step-by-step development, and DEA collaborations with relevant research institutions.

Sources: (Government of South Africa, 2015 [51]); (Mahadevan, 2015 ${ }_{[54]}$ ); (McNicoll et al., 2017 ${ }_{[37]}$ ).

101. Ghana's Environment Protection Agency (EPA) and Indonesia's Directorate General of Climate Change have less experience comparatively, having established purpose-built systems in 2013 and 2016 only (Table 11). Both countries are still improving methods, procedures and institutions for their respective monitoring systems. Indonesia's new purpose-built monitoring system, the National Registry System (SRN), 
still relies on the voluntary submission of data, without any formal mandate for data collection. The country is yet to use its SRN system to report on climate finance received as part of a BUR or NC.

102. Other non-Annex I countries use existing public financial management monitoring systems to identify climate finance received. Existing monitoring systems, where established, are primarily designed to track public expenditure, including onbudget official development assistance (ODA) and to some extent foreign direct investment. Some countries have adapted their systems to include climate finance received by using a tagging and marking system, following the same criteria as those applied to their domestic budgets. This approach often consists of applying a climate element to public expenditure reviews in the form of a climate public expenditure and institutional review (CPEIR), climate-change financial assessment or analysis, or a mitigation fiscal framework ( (World Bank, 2014 ${ }_{[55]}$ ) in (Ellis and Moarif, 2016 $\left.{ }_{[2]}\right)$ ).

103. Monitoring climate finance using existing public financial management monitoring systems has both advantages and drawbacks. Countries taking this approach can mainstream climate change into their public financial management systems, but they may face capacity issues, particularly when trying to cover international flows to nongovernmental organisations or from the private sector. They may face technical challenges in meeting requests for international reporting, including the forthcoming transparency framework of the Paris Agreement, such as inconsistent markers, indicators or codes for different types of financial data. There may be challenges in identifying amounts specifically allocated to climate change due to limited institutional capacity in some instances (Tirpak, Brown and Ronquillo-Ballesteros, 2014 ${ }_{[56]}$ ) (Tirpak, Stasio and Tawney, 2012 ${ }_{[48]}$ ) (Mazza et al., 2016 $6_{[57]}$ ).

104. Nepal is an example of a developing country that monitors climate change expenditure, including climate finance received, using a budget code system (Government of Nepal, 2012 $2_{[58]}$ ). This system was adapted and decentralised to the district level in 2016 under the UNDP's climate public expenditure and institutional review (CPEIR) initiative (Table 17). A pilot study of five districts shows that decentralised monitoring allows the government to capture finance received by local NGOs and to some extent the private sector (UNDP, forthcoming). However, districtlevel reporting is not yet aggregated, which impedes calculating (and reporting) a national total.

105. Both Ghana and Indonesia are adapting existing public financial management monitoring systems to track climate finance received as part of efforts to improve the effectiveness of public expenditure, in parallel to developing purpose-built monitoring systems. Indonesia is attempting to integrate the two monitoring systems in recognition of the potential duplication of effort.

\subsection{Financial support needed}

\subsubsection{Key lessons from current reporting experience}

106. Several, but not all, non-Annex I Parties provide information on their financial needs in reporting on constraints, gaps and related needs in their BURs (Annex III FCCC/CP/2011/9/Add.1). Information on financial support needed has been included in 24 non-Annex I Parties' BURs to date, with varying levels of information and detail. 
Many Parties report details of finance needed as part of broader reporting on technical, technology and capacity building needs. A few Parties provide specific information or a summary table on finance needed. For example, South Africa provided a summary table on finance needed with information on the proposed sector and activity, reference to policies and measures, the specified amount in USD and local currency, the specific type of support required and funding amount broken down by preferred type (loan, grant, or in-kind). However, most Parties that include information on finance needed refer to sectors or proposed projects requiring funding, without providing further project details such as a quantified estimate for finance needed or an explanation about their methodological assumptions (Table 12). The CGE has suggested tables for reporting on finance needed, but few countries except Mongolia have used them. The limited information on finance needed provided by Parties most likely reflects capacity constraints.

107. As well as reporting in BURs, non-Annex I Parties are encouraged to provide a list of projects, programmes or other activities proposed for financing in their NCs (FCCC/CP/2002/7/Add.2). Nearly half of the 151 NCs submitted by non-Annex I Parties include information on their financial needs. Although some non-Annex I Parties have not yet submitted a BUR, information on finance has been included in their NCs. Some non-Annex I Parties also include information on finance needed as part of NDCs if targets are conditional on receiving finance.

Table 12. Information on financial support needed in non-Annex I Parties’ BURs

\begin{tabular}{l|c|c}
\hline & $\begin{array}{c}\text { Number of BURs where this information is } \\
\text { reported }\end{array}$ & \multicolumn{1}{c}{ Examples } \\
\cline { 2 - 3 } Qualitative estimate & 13 & China, Ghana, Morocco, South Africa \\
\hline Methodological explanations & 8 & Chile, Indonesia, Republic of Moldova \\
\hline $\begin{array}{l}\text { Quantitative value for finance needs, } \\
\text { aggregated }\end{array}$ & 4 & Chile, Ghana, South Africa \\
\hline $\begin{array}{l}\text { Quantitative value for finance needs by sub- } \\
\text { sector }\end{array}$ & 8 & India, Malaysia, Paraguay \\
\hline Project pipeline & 7 & Mauritania, Namibia, Tunisia \\
\hline
\end{tabular}

Source: Non-Annex I countries BURs (UNFCCC).

\subsubsection{Reporting arrangements outside the UNFCCC}

108. A review of reporting arrangements outside the UNFCCC as reflected in national studies and submitted BURs reveals two main approaches to estimating climate finance needs (Table 13). The first approach consists of estimating climate finance needs at the aggregate or sectoral level (top-down approach). The second approach involves aggregating estimated budgets of specific mitigation or adaptation projects in the development pipeline (bottom-up approach).

109. The first approach often features as part of the development of National Climate Change Plans, vulnerability needs assessments, and NCs and BURs (Sekulić et al., 2013 ${ }_{[59]}$ ); (Wen and Xun, 2016 $6_{[60]}$ ). Presented as stand-alone documents, the reports are then often cited and used as part of reporting to the UNFCCC. Parties' aggregate estimates mainly focus on needs relating to mitigation projects or programmes, especially for the energy and transport sectors. Some Parties (e.g. India) focus exclusively on mitigation activities in BURs, in cases where monitoring and reporting arrangements are not available for adaptation activities. 
110. The bottom-up approach to monitoring financial needs tends to be updated on an ongoing basis, given the aim of consolidating information from project development pipelines. Indonesia (DNPI, 2010 $[61]$ ) and Ghana (ECN, 2010 ${ }_{[62]}$ ) apply marginal abatement cost curves to help develop sectoral estimates in mitigation sectors. Methods used to estimate adaptation finance needs are less developed.

111. Both the bottom-up and top-down approaches have advantages and disadvantages. The top-down approach can result in an overarching and long-term view by sector over a specified period of time, but limited or unclear assumptions may mean that methodologies applied may not be sufficiently robust or clear. Of course, these shortcomings may be resolved over time. The bottom-up approach is more transparent and may help developing countries promote priority projects for investment and secure international support. The bottom-up approach may, however, be less suited to helping identify priority sectors, and may be constrained by the capacity of governments and project developers to ensure bankable project proposals. Where countries use both approaches, there is limited evidence of countries trying to reconcile the outcomes of the two approaches, or understand their distinctions and complementarities. Indonesia, Ghana, South Africa, Montenegro and Vietnam are examples of countries that use both approaches. 
Table 13. Examples of non-Annex I country reporting arrangements for climate finance needs

\begin{tabular}{|c|c|c|}
\hline Country & $\begin{array}{c}\text { Top-down approach } \\
\text { (aggregate estimate of finance needs) }\end{array}$ & $\begin{array}{l}\text { Bottom-up approach } \\
\text { (finance needs based on project pipeline) }\end{array}$ \\
\hline China & $\begin{array}{l}\text { Various estimations conducted by national research institutions, } \\
\text { e.g. estimation by National Center for Climate Change Strategy } \\
\text { and International Cooperation* and by the Energy Research } \\
\text { Institute (ERI) (Bo and Yao,(n.d.)[63]) }\end{array}$ & - \\
\hline $\begin{array}{l}\text { Former Yugoslav } \\
\text { Republic of } \\
\text { Macedonia }\end{array}$ & - & $\begin{array}{l}\text { National arrangements to manage climate change project } \\
\text { data with UNDP support, Proaktiva.org* (Government of the } \\
\text { Republic of Macedonia, 2014[64]) }\end{array}$ \\
\hline Ghana & $\begin{array}{l}\text { Marginal abatement cost curve analysis conducted in } 2010 \text { as } \\
\text { part of Technical Assistance to Ghanaian National Climate } \\
\text { Change Policy Framework }{ }^{\star} \text { (NCCPF) (ECN, 2010[62]) }\end{array}$ & $\begin{array}{l}\text { Online platform hosted by Ghana's Environmental } \\
\text { Protection Agency provides a GCF project pipeline, } \\
\text { including requested modalities and the status of listed } \\
\text { projects }^{\star \star}\left(E P A, 2017_{[49]}\right)\end{array}$ \\
\hline India & $\begin{array}{l}\text { Sectoral and regional analysis for the } 2030 \text { s carried out by } \\
\text { Ministry of Environment and Forests* (Government of India, } \\
2007_{[65])}\end{array}$ & - \\
\hline Indonesia & $\begin{array}{l}\text { DNPI study in } 2009 \text { using marginal abatement cost curve* } \\
\text { (DNPI, 2010); Ministry of Finance estimation based on indicative } \\
\text { cost* }^{*} \text { (Government of Indonesia, 2015[66]) }\end{array}$ & $\begin{array}{l}\text { Unpublished GCF project pipeline developed by Ministry of } \\
\text { Finance; NAMA database collected by Ministry of } \\
\text { Development Planning* (Bappenas, 2013[67]) }\end{array}$ \\
\hline Montenegro & $\begin{array}{l}\text { Estimates of climate finance needs across some sub-sectors ** } \\
\left(E U, 2014_{[68]}\right)\end{array}$ & $\begin{array}{l}\text { Single Project Pipeline (SPP) managed by National } \\
\text { Investment Committee (NIC) accommodates data collection } \\
\text { on investment priorities for environment* }{ }^{\star E U, ~ 2014[68]) ~}\end{array}$ \\
\hline Serbia & - & National Vulnerability Assessment** (Sekulić et al., 2013[59]) \\
\hline South Africa & $\begin{array}{l}\text { Estimates of climate finance needs, mainly in the energy sector* } \\
\text { (Government of South Africa, 2014[69]) }\end{array}$ & $\begin{array}{l}\text { Unpublished project-level data from Department of } \\
\text { Environmental Affairs covering sector, activity, reference to } \\
\text { policies, amounts needed, purpose and type of funding } \\
\text { needed* (Government of South Africa, 2014[69]) }\end{array}$ \\
\hline Viet Nam & $\begin{array}{l}\text { Cost estimates conducted, but results insufficiently detailed }{ }^{\star *} \\
\text { (Henzler,(n.d.)[70]) }\end{array}$ & $\begin{array}{l}\text { Developed based on Climate Public Expenditure and } \\
\text { Institutional Review supported by the UNDP* (Government } \\
\text { of the Socialist Republic of Viet Nam, 2014[71]) }\end{array}$ \\
\hline Zambia & - & $\begin{array}{l}\text { Zambia's project pipeline in Zambia's country programme } \\
\text { submitted to the GCF** (GCF, 2017[72]) }\end{array}$ \\
\hline
\end{tabular}

Note: There may also be formal arrangements in countries other than those listed above that are not included in this table due to challenges in accessing relevant information.

*Cited in BUR and/or NC.

**Not cited in the submitted BUR and/or not clear, although in existence.

\subsection{Proposing an enhanced finance reporting system for developing countries}

112. Enhanced systems for developing country reporting on climate finance received and needed can bring benefits at both the national levels, as well as being useful internationally in the context of the UNFCCC. These include improved efficiency (e.g. in terms of time and human resources) and effectiveness (e.g. accuracy) in capturing and communicating budgeting and financial information, and better knowledge-sharing among national and international stakeholders through dialogue, data-sharing and analysis (UNFCCC, 2015 $5_{[73]}$ ) (UNFCCC, 2016 ${ }_{[74]}$ ). Enhanced transparency can assist governments and civil-society groups identify and review the scale and type of climate finance received by a country (Moncel and Stasio, 2011 ${ }_{[75]}$ ), and priority areas for timely international support. It can help document appropriate disbursement of finance received 
and demonstrate progress towards intended objectives, potentially facilitating further support (CDKN, 2012 $2_{[76]}$ ) (Moncel and Stasio, 2011 ${ }_{[75]}$ ).

113. An enhanced climate finance reporting system for developing countries could build upon existing public financial and monitoring systems; if a country's systems cannot for whatever reason accommodate further expansion, a country can conduct a cost-benefit analysis to consider developing a new, purpose-built system to monitor its inflows and expenditure. The latter approach requires several years of consistent data collection and could therefore have important resource implications for developing countries. By improving existing public financial and monitoring systems or developing a new purpose-built system, countries can aim to ultimately equip any system with dataverification functions, and even data analysis and visualisation functions.

114. Developing countries can take an incremental approach to building a monitoring system for reporting on climate finance. This gradual development has been applied elsewhere in the UNFCCC, e.g. the UNFCCC's stepwise framework for setting REDD+ forest reference emission levels and forest reference levels (Herold et al., 2012[77]). Armed with a roadmap detailing a gradual improvement plan, developing countries can progressively improve their capacity for reporting. Countries have the option of starting with selected information, e.g. that listed in Box 2 and adding further reporting elements over time. Table 14 shows how arrangements for reporting climate finance can be developed gradually, in three stages or more if necessary. Enhanced general financial reporting on climate finance both received and needed includes information on activities relating to mitigation and/or adaptation. It could also eventually include information on the instruments and institutions used to channel this climate finance. 
Table 14. Gradual approach to enhancing climate finance monitoring and reporting systems by developing countries

\begin{tabular}{|c|c|c|c|c|}
\hline Section & Element & Stage 1 & Stage 2 & Stage 3 \\
\hline \multirow{7}{*}{$\begin{array}{l}\text { General } \\
\text { financial } \\
\text { monitoring for } \\
\text { both climate } \\
\text { finance needed } \\
\text { and received }\end{array}$} & $\begin{array}{l}\text { Data verification } \\
\text { process }\end{array}$ & $\begin{array}{l}\text { Data verification process } \\
\text { by custodian to improve } \\
\text { accuracy }\end{array}$ & $\begin{array}{l}\text { Data verification process by } \\
\text { custodian and experts to } \\
\text { improve accuracy }\end{array}$ & $\begin{array}{l}\text { Data verification process by } \\
\text { custodian, experts and another party } \\
\text { (if possible) to improve accuracy }\end{array}$ \\
\hline & Data management & $\begin{array}{l}\text { Limited climate finance } \\
\text { data from government- } \\
\text { registered projects or } \\
\text { combined external data }\end{array}$ & $\begin{array}{l}\text { A national database of climate } \\
\text { finance received by national } \\
\text { and some sub-national } \\
\text { institutions and needed is } \\
\text { established and updated on an } \\
\text { ad hoc basis }\end{array}$ & $\begin{array}{l}\text { A national database for climate } \\
\text { finance received by national and sub- } \\
\text { national institutions is established and } \\
\text { updated periodically (i.e. every } 6 \\
\text { months) and can be transferred to the } \\
\text { UNFCCC or CTF interface using a } \\
\text { macro tool. }\end{array}$ \\
\hline & Sectoral coverage & $\begin{array}{l}<3 \text { key sectors, such as } \\
\text { energy (mitigation) and } \\
\text { water (adaptation) }\end{array}$ & $\begin{array}{l}\text { All key sectors, energy, } \\
\text { transport, forestry and other } \\
\text { sectors (mitigation) and water, } \\
\text { food, agriculture and other } \\
\text { sectors (adaptation) }\end{array}$ & $\begin{array}{l}\text { All sectors; sub-sectors such as } \\
\text { renewable energy, energy efficiency, } \\
\text { energy policy development and others } \\
\text { under the energy sector are identified }\end{array}$ \\
\hline & Theme & $\begin{array}{l}\text { Mitigation only or } \\
\text { adaptation only }\end{array}$ & $\begin{array}{l}\text { Mitigation and adaptation with } \\
\text { one more dominant than the } \\
\text { other }\end{array}$ & $\begin{array}{l}\text { Mitigation and adaptation are } \\
\text { presented equally }\end{array}$ \\
\hline & Instrument & Selected instruments & Grant or/and loan & All instruments \\
\hline & Data period & $1-2$ years & $3-5$ years & More than five years \\
\hline & $\begin{array}{l}\text { Scope (institution and } \\
\text { geography) }\end{array}$ & $\begin{array}{l}\text { Public (government only); } \\
\text { national only }\end{array}$ & $\begin{array}{l}\text { Public (government and non- } \\
\text { government); national only }\end{array}$ & Public and private; sub-national \\
\hline \multirow[t]{2}{*}{$\begin{array}{l}\text { Approach to } \\
\text { reporting of } \\
\text { climate finance } \\
\text { needs }\end{array}$} & $\begin{array}{l}\text { Sectoral } \\
\text { project/programme } \\
\text { pipeline or policy } \\
\text { development }\end{array}$ & $\begin{array}{l}\text { Gaps in many sectors; } \\
\text { strong project/programme } \\
\text { pipeline or policy } \\
\text { development in one to two } \\
\text { sectors only }\end{array}$ & $\begin{array}{l}\text { Gaps in some sectors; strong } \\
\text { project/programme pipeline or } \\
\text { policy development in four or } \\
\text { five sectors }\end{array}$ & $\begin{array}{l}\text { Gaps in a few sectors; strong } \\
\text { project/programme or policy } \\
\text { development pipeline in almost all } \\
\text { sectors }\end{array}$ \\
\hline & $\begin{array}{l}\text { Estimation using } \\
\text { modelling technique }\end{array}$ & $\begin{array}{l}\text { Mitigation only or key } \\
\text { sectors only }\end{array}$ & $\begin{array}{l}\text { Some key sectors of mitigation } \\
\text { and adaptation }\end{array}$ & $\begin{array}{l}\text { All sectors of mitigation and } \\
\text { adaptation, and joint mitigation and } \\
\text { adaptation }\end{array}$ \\
\hline \multirow{2}{*}{$\begin{array}{l}\text { Approach to } \\
\text { reporting of } \\
\text { climate finance } \\
\text { received }\end{array}$} & $\begin{array}{l}\text { Dedicated climate } \\
\text { finance monitoring } \\
\text { system }\end{array}$ & $\begin{array}{l}\text { Web-based platform } \\
\text { established }\end{array}$ & $\begin{array}{l}\text { Web-based platform supported } \\
\text { by partnerships with national } \\
\text { and international stakeholders }\end{array}$ & $\begin{array}{l}\text { Web-based platform supported by } \\
\text { national key stakeholders through } \\
\text { formal mandates }\end{array}$ \\
\hline & $\begin{array}{l}\text { Expansion of existing } \\
\text { public finance } \\
\text { monitoring system }\end{array}$ & $\begin{array}{l}\text { Procedures such as. } \\
\text { tagging/marking are } \\
\text { included to identify climate } \\
\text { change activities in the } \\
\text { existing dataset }\end{array}$ & $\begin{array}{l}\text { The scopes of climate finance } \\
\text { aspects, e.g. grants and loan, } \\
\text { bilateral and multilateral, public } \\
\text { and private finance, etc., can } \\
\text { be covered by an extended } \\
\text { mandate }\end{array}$ & $\begin{array}{l}\text { The broad coverage of climate } \\
\text { finance data is supported by a stable } \\
\text { physical and/or virtual communication } \\
\text { platform that periodically convenes } \\
\text { key stakeholders. }\end{array}$ \\
\hline
\end{tabular}

Note: Adapted from (Herold et al., 2012[77]) stepwise approach to establishing forest reference emission levels and South Africa’s M\&E development approach.

115. Arrangements for reporting climate finance received can be enhanced by employing a method for collecting data consistently from the start. The introduction of CTF tables in 2013 has improved the consistency and comparability of developed countries' reporting (although further improvements are still possible, as noted in section 
4.3). Developing countries could consider Box 2 and adopt, where relevant, useful elements for reporting according to their capacity.

\section{Box 2. Potential elements for developing country reporting of climate finance received}

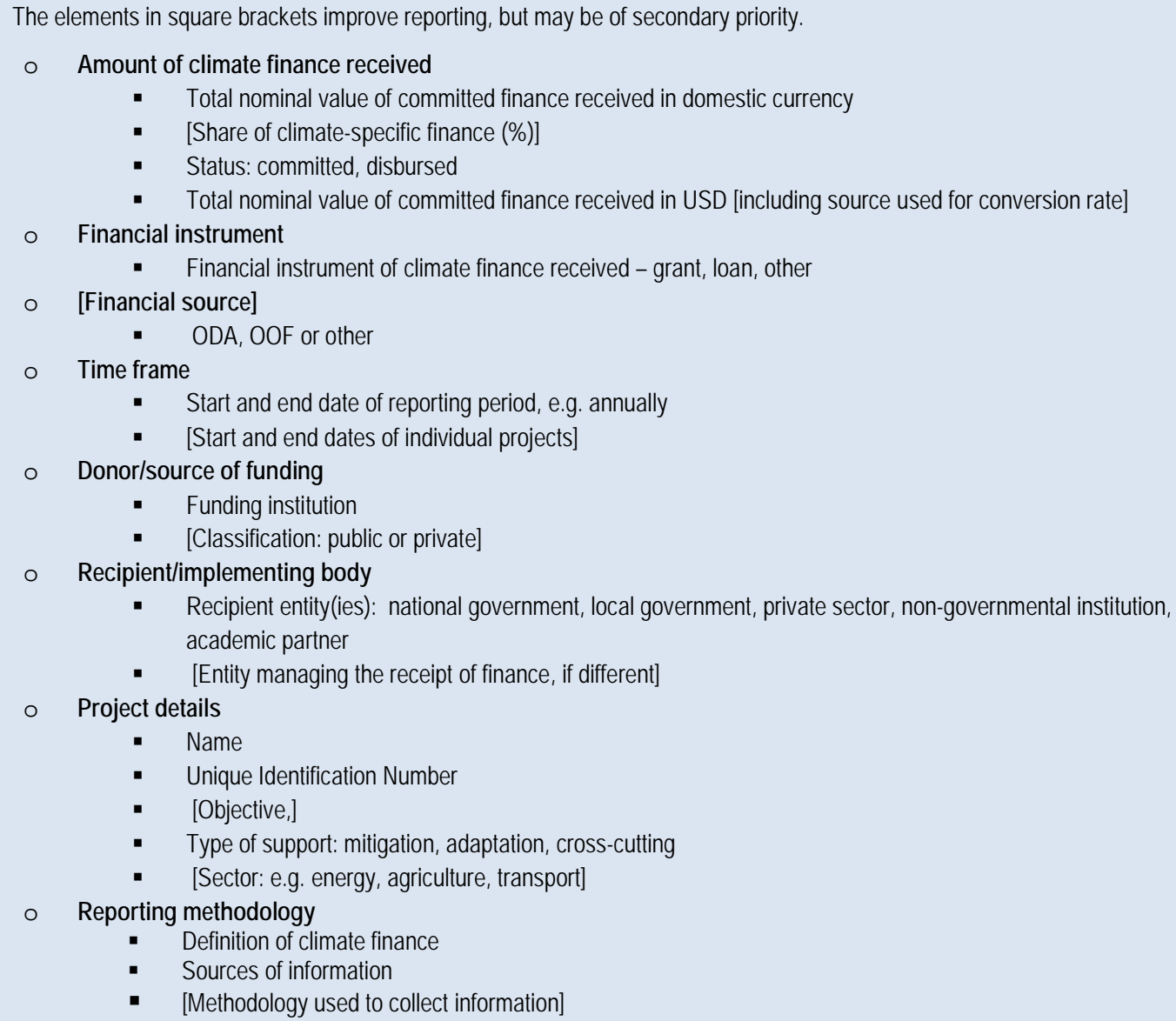

116. An enhanced approach to estimating and reporting finance needed could initially focus on the development of a publicly-accessible pipeline of priority projects and programmes, as a sub-set of information on climate finance needs. ${ }^{41}$ If presented in the form of a searchable database, such a pipeline could potentially allow stakeholders to filter and search for relevant financial information without needing to refer to multiple project documents. Developing countries could consider Box 3 and adopt, where relevant, useful elements for reporting on finance needs associated with projects and programmes, according to their capacity.

${ }^{41}$ Countries may also need climate finance to establish long-term strategies and legal and regulatory frameworks, build institutional capacity etc. 


\section{Box 3. Potential elements for developing-country reporting of climate finance needed (project and programme focus)}

The elements in square brackets improve reporting, but may be of secondary priority.

o Unique Identification Number

o Amount of climate finance needed

- Total nominal value of committed finance needed in domestic currency

- [Share of climate-specific finance (\%)]

- Total nominal value of finance needed in USD [including source of conversion rate used]

o Amount of co-finance needed

- Total nominal value of finance needed from secondary public institutions in the form of financial support or capacity-building/technical assistance

- Total nominal value of finance needed from secondary private institutions to co-finance the total amount required from the primary source, in the form of financial support or capacity-building/technical assistance)

o Preferred financial instrument

- Preferred financial instrument supplying climate finance needed- grant/loan/other

0 Expected funding time-frame

- Duration of project/programme finance

o Recipient/implementing body

- Recipient organisation

- [Classification: national government/local government/private sector/NGO/academic partner]

- [Organisation managing the finance, if different]

o Project details

[Classification: national/direct/international access]

- Name

- Status of project: idea/concept; note/draft proposal/final proposal

- Project/programme location(s)

- $\quad$ Objective\}

- $\quad$ Type of support: mitigation/adaptation/cross-cutting

- [Name of government partner(s) if any]

- [Link to national priority programme]

- [Link to national/sub-national regulatory support]

o Reporting methodology

- Definition of climate finance

- Sources of information

- [Methodology used to collect information]

117. Reporting the uses and results (e.g. outputs, outcomes and impacts) of climate finance received are elements for developing countries to consider under the Paris Agreement's enhanced transparency framework. Demonstrating a causal link between climate finance and the results of that finance is challenging for all countries particularly for adaptation-related activities. It is one of the areas where both developed and developing countries need to make significant improvements; developing countries will require extensive support. Vandeweerd et al. (2012) outlines a framework for countries to monitor the impact of government finance allocated to climate change under national monitoring systems (Vandeweerd, Glemarec and Billett, 2012[78]]). The framework could be further developed to include climate finance received.

118.

In monitoring the use and results of climate finance received, developing countries could assess the feasibility of applying quantitative and qualitative methodologies used by donors and multilateral agencies that have extensive experience with monitoring climate projects and programmes. Multilateral climate funds such as Climate Investment Funds use a quantitative approach to assessing the impacts of their funded programmes (CIF, $\left.2014_{[79]}\right)$. Oher donors employ other frameworks, such as systems that evaluate 
effectiveness and value for money, to assess the outcome of climate projects and programmes (ICAI, 2011 $1_{[80]}$ ). Such experience is useful, as outcome assessments and impact evaluations can take several years and are costly, requiring specialised expertise, robust baseline data, and the involvement of independent evaluators and project or programme staff (Goldstein,(n.d.) ${ }_{[81]}$ ) (White, 2009 [82] $)$.

\section{Conclusions}

\section{Overarching considerations}

119. The design of the enhanced transparency framework under the Paris Agreement is to build on current reporting arrangements for mitigation and finance adopted at COP16 in Cancún. One of the overarching key lessons is that adopting common reporting guidelines do not mean that Parties have to report the same information in the same way, or calculate them in the same way, with the same level of certainty, or report them at the same frequency. A common framework can allow for flexible implementation, while giving Parties with relatively less experience an objective to strive towards and improve over time. Inherent in this paper is the view that reporting guidelines could be ambitious, and aim to reflect the complete set of information Parties want from each other, even if some Parties are not able to report all of this information at present. An ambitious and flexible reporting framework can nevertheless acknowledge that improvement in reporting will occur over time, with sustained effort and support.

120. Under the Paris Agreement, the framework for reporting serves two purposes: clarity and tracking of progress towards achieving NDCs, and informing the global stocktake (GST) under Article 14. Although the precise modalities and sources of input for the GST are yet to be defined, the global stocktake aims to take comprehensive stock of collective progress towards the long-term goals of the Paris Agreement, including those on mitigation and means of implementation and support. If the transparency framework is to provide inputs for the global stocktake, the framework's modalities, procedures and guidelines will need to carefully consider the consistency and comparability of the information Parties are asked to report, mindful of the flexibility in implementation provided to developing country Parties who need it in light of their capacities. Reporting guidelines would need to support the provision of consistent and comparable information from Parties by being as clear and specific as possible, to avoid inconsistent interpretations and minimise effort required from Parties to follow the guidelines. Developing common formats and online tools (or building upon existing ones) could also facilitate the aggregation of information, particularly for greenhouse gas inventories and financial information; these areas are both data-heavy and can draw on calculation tools and databases developed outside the UNFCCC.

121. Besides greater consistency and completeness of information to inform the global stocktake, the Paris Agreement also implies two additional enhancements to reporting, compared with current arrangements. The first stems from an emphasis on facilitating improved reporting over time (Paragraph 92 of decision 1/CP.21) and on a transparency framework that builds trust, confidence and promotes effective implementation (Article 
13.1 of the Paris Agreement). Within such a framework, modalities, procedures and guidelines (MPGs) for reporting could provide guidance to Parties on communicating in a way that improves mutual understanding and learning, rather than simply specifying a piece of information or number to report.

122. The second enhancement implied is one of domestic capacity. Countries can only report information they have; as such, most countries will need to enhance domestic efforts to monitor and collect data and information significantly. Domestic policy is in itself an important driver for governments to improve data monitoring and policy analysis: planning for any budget or implementing any policy measure requires sound data. As such, the Paris Agreement could stimulate a virtuous cycle in increasing ambition, improving data availability and enhancing transparency. NDCs could lead to more ambitious domestic climate policies, which may in turn elicit the need for sound data. The various transparency-related initiatives providing support to countries should further enable these domestic processes.

\section{Conclusions on mitigation reporting}

123. The challenge in developing guidelines for mitigation-related reporting under the Paris Agreement is one of balance. One issue is that of balancing the need to accommodate different country capacities with enabling continuous improvement for all Parties. Within the context of a common set of MPGs, developing countries that need it are to be accorded flexibility, distinct from the blanket flexibility accorded LDCs and SIDS by Paragraph 90 of decision 1/CP.21. In addition, countries are to maintain at least their current level of reporting (frequency and quality). Parties have proposed different ways of operationalising flexibility beyond the "built-in" flexibility that different NDCs presuppose, including via certain "criteria" (e.g. United States) or more commonly via self-identification of the need for flexibility (e.g. African Group), whereby Parties themselves determine the level of flexibility they need, and would apply guidance and report information accordingly. This paper proposes an option closer to selfidentification, based on current experience, assuming that countries report to the best of their abilities, and will work to improve reporting of information which is mandatory, as well as information that highlights their mitigation efforts and achievements, or is helpful for building useful domestic capacities.

124. In terms of options for balancing flexibility with continuous improvement, the paper suggests including the principle of "no backsliding" from current levels of reporting upfront in both inventory and progress report guidelines. The technical expert review process could also review progress reports in light of any previous reports submitted by the Party. Explicitly including improvement plans within biennial reporting would also allow for transparency around a country's self-identification of flexibility needs. Parties could transparently indicate what parts of the progress report or national inventory report (NIR) they will not be able to complete, and identify the parts they aim to complete in their next reports.

125. Communicating improvement plans in the context of progress with NDCs has no obvious parallel in existing reporting guidelines. As such, detailed guidance on how to report this information may be important within future MPGs. Parties unable to submit either a NIR or a progress report (or both) on a biennial basis could transparently announce at what interval they will aim to submit their subsequent reports. Linking more transparent reporting of capacity needs with priority improvement areas, and including recommendations and suggestions for ways of reporting information within the guidelines (along with supporting materials as needed), should also help Parties with 
more limited capacity. During the September 2017 CCXG Global Forum, a participant also suggested the development of a "capability matrix", through which Parties could assess their current level of capability for different reporting areas, and link this to their support needs and improvement plans.

126. A second challenge is balancing the need to accommodate the diversity of nationally determined contributions (NDCs) with the goal of informing the global stocktake. In response, guidelines may contain much more detail and more options for reporting compared with current biennial report (BR) and biennial update report (BUR) guidelines, with different parts of the guidance applicable either to all Parties or relevant specifically to Parties' different NDCs; this is what many Party submissions have suggested (e.g. AILAC, AOSIS, Australia, New Zealand, Korea, South Africa). Having guidance with enough detail and options to be relevant to all Parties builds on a key lesson learned from the implementation of non-Annex I BUR guidelines, which do not provide any options for how a Party with a given form of mitigation objective could communicate this transparently via its BUR.

127. One lesson from current experience is that it is difficult to report information clearly and consistently if it is difficult to measure and estimate this information. As such, developing accounting guidance to provide a set of common methods for Parties to use as relevant could help countries assess progress with their NDCs. Parties may also need to discuss a minimum set of common metrics, definitions and information they can all use to facilitate their reporting. For the global stocktake, in the context of mitigation, reporting guidance could include information relevant for the purpose of a collective assessment in the future, even though it may not be immediately relevant to communicating progress with a Party's nationally determined contribution. An example of this information could be the reporting of emissions projections, which for the purpose of being useful to the global stocktake projections, would likely also need to indicate an emissions trajectory (as opposed to projecting a single number referring to emissions in 2030).

128. Both challenges listed above would benefit from guidelines that provide useful suggestions and advice to help Parties know what to report, how to report it, and why this information is important. Whether this level of detail is contained within the reporting guidelines themselves, or in accompanying guidance documents, is for Parties to discuss.

\section{Conclusions on finance reporting}

129. The guidelines for reporting finance provided and mobilised under the Paris Agreement can build on ongoing learning, including from the experience with common tabular format (CTF) tables. The CTF tables were established in 2013 and revised in 2015, to be used for the third round of BRs due by 1 January 2018. Despite improvements in reporting since the introduction of CTF tables, there remains scope for Parties to further clarify information provided on definitions used and methodological approaches to reporting on finance provided and mobilised to facilitate comparability. In some cases, countries could also provide more granular information, including on bilateral flows. Assessing how consistently the CTF tables are used by Parties can provide the basis for further revisions, if needed, such as suggested common sources and references. In order to implement the reporting provisions of the Paris Agreement, Parties may also wish to clarify the interpretation of new terms introduced, such as "scaling up" or "progression beyond previous efforts", as they see fit to facilitate convergence. 
130. The Paris Agreement's provisions require reporting Parties to address two further gaps in particular: the lack of experience in reporting private finance mobilised to date, and the possibility to accommodate new reporting Parties, while ensuring the information is useful for recipient Parties. This paper suggests four main opportunities for enhanced transparency that Parties could consider in designing MPGs for the reporting of finance provided and mobilised:

- Including the reporting of private finance mobilised through bilateral public interventions in CTF reporting, for example by revising existing table 7(b) or creating a new CTF table 7(c);

- Encouraging activity-level reporting from multilateral public finance providers to the UNFCCC on public finance provided and private finance mobilised through multilateral channels, with the aim of increasing consistency and avoiding doublecounting;

- Encouraging “other Parties” to build on Annex II Parties' experience by reporting on climate finance using the most up-to-date reporting tables, and start collecting and reporting data for the categories for which they are missing information;

- Allowing more flexible reporting tools, or creating an online interface enabling data export and personalised searches, to make the reporting of information less time-consuming, and the information more accessible to developing country Parties.

131. Developing countries have limited experience with reporting on financial support received and needed, although some countries have developed purpose-built systems to monitor financial support received that are integrated with overall monitoring of climate change mitigation and adaptation activities. Many Parties state challenges in collecting financial information in their BURs. The development of MPGs for the reporting of information on climate finance received and needed under the Paris Agreement could usefully support developing countries to:

- Build on existing public financial and monitoring systems as a way of drawing on existing capacity to enhance reporting on climate finance received and needed;

- Gradually improve arrangements for reporting, including by identifying basic reporting elements for climate finance received and needed as a starting point to help promote consistency and comparability of reporting;

- Drive bottom-up efforts to estimate and report on finance needs through a focus on the development of publicly-accessible pipelines of mitigation and adaptation projects and programmes, as a sub-set of information on climate finance needs.

\section{Further work}

132. Parties have begun outlining the possibilities for what reporting under an enhanced transparency framework might look like, and still need to address many questions and issues. This includes exploring how to combine specificity and flexibility in guidelines, and considering what flexible implementation of reporting guidelines might look like in practice for developing countries.

133. In the light of the lessons drawn from existing experience and the enhancements stemming from the Paris Agreement, Parties could consider the following approaches to move forward with development of reporting guidelines: 
- Accelerate work in areas on which there may be more consensus among Parties, such as GHG inventory reporting (APA, 2017 $[11])$. On other topics, Parties can focus on the essential pieces of information they would like reported, as well as the types of guidance Parties might need to help them report that information. Parties could also discuss which types of information they would like all Parties to report, and which specific types of information may be relevant only to specific types of NDCs.

- Closely co-ordinate with work on developing accounting guidance for NDCs and finance, under the ad-hoc working group on the Paris Agreement (APA) and subsidiary body for scientific and technology advice (SBSTA) respectively, to ensure both sets of guidance are consistent and enhance reporting of information.

- For mitigation, begin working through each sub-heading of the outlines presented in the APA non-paper (APA, 2017 ${ }_{[11]}$ ), discussing in concrete terms what information would need to be reported under these sub-headings. Discussions could begin with clarifying what the sub-headings refer to, such as the distinction between reporting on progress with implementation vs. achievement, and what information on "national circumstances" might specifically cover. Related to the above point, the sub-headings could be used to clarify specific links between accounting and reporting, such as whether guidance on indicators to track progress are to be developed as part of the reporting or accounting guidance.

- Also for mitigation, enable the Secretariat to proactively gather feedback from all Parties on existing reporting guidelines and tools, including online tools for greenhouse gas inventory reporting. In some cases, this might mean allowing all Parties access to the same tools in order to gather a broad range of views.

- Consider how future reporting formats could encourage inclusion of gender data pending the outcome of the UNFCCC Secretariat technical paper on entry points to integrate gender considerations into UNFCCC work streams, which was requested by Decision 21/CP.22 and is to be considered by the Subsidiary Body for Implementation between April and May 2018.

134. Though not referred to in the Paris Agreement, Parties could also draw lessons from experience with reporting information within national communications. One lesson highlighted by expert reviewers is that inconsistencies between different sets of guidelines can make reporting more challenging (Briner and Moarif, 2016 $6_{[1]}$ ). Parties may therefore consider existing Convention processes related to the revision and update of guidelines for national communications to ensure there will be consistency and coherence between future reporting of national communications, and future reporting under the Paris Agreement. 


\section{Annexes}

Table 15. Current content of inventory submission guidelines (Decision 24/CP.19)

\begin{tabular}{|c|c|}
\hline & Table Column Heading (Alt+O) \\
\hline A. Objectives & $\begin{array}{l}\text { Overarching goals, i.e. to assist Parties meet commitments, ensure transparency, } \\
\text { improve quality of inventories, facilitate review Table Cell (Alt+E) }\end{array}$ \\
\hline B. Principles and definitions & $\begin{array}{l}\text { Each element of TACCC (principles) defined; refers Parties to definitions in IPCC } \\
2006 \mathrm{GL}\end{array}$ \\
\hline C. Context & $\begin{array}{l}\text { Explains GL cover establishment and maintenance of inventory arrangements, } \\
\text { that submission consists of NIR and CRF tables }\end{array}$ \\
\hline D. Base year & Specifies 1990 as base year for inventories, lays out exceptions \\
\hline \multicolumn{2}{|l|}{ E. Methods } \\
\hline Methodologies & $\begin{array}{l}\text { Specifies use of IPCC } 2006 \mathrm{GL} \text {, provides guidance on usage of } \\
\text { tiers, EFs, AD, KCA, LULUCF }\end{array}$ \\
\hline Key category identification & Requires use of approach 1 \\
\hline Uncertainties & Requires at least approach 1 per IPCC $2006 \mathrm{GL}$ \\
\hline Recalculations and time-series consistency & $\begin{array}{l}\text { Guidance on using same methodologies for time series, } \\
\text { recalculations }\end{array}$ \\
\hline QA/QC & $\begin{array}{l}\text { Requires QA/QC plan and QC procedures; some guidance on what } \\
\text { this should comprise }\end{array}$ \\
\hline $\begin{array}{l}\text { F. National Inventory Arrangements } \\
\text { - Inventory Planning } \\
\text { - Inventory Preparation } \\
\text { - Inventory Management }\end{array}$ & $\begin{array}{l}\text { Guidance on inventory arrangements, how they should be designed and } \\
\text { operated, generally function, and specific guidance on planning, preparation and } \\
\text { management (no mandatory language). Includes reporting on planned inventory } \\
\text { improvements. }\end{array}$ \\
\hline G. Reporting & Outlines what should be reported in NIR and CRF tables \\
\hline $\begin{array}{l}\text { 1. General guidance } \\
\text { Estimates of emissions and removals }\end{array}$ & $\begin{array}{l}\text { Gases to be covered (shall, should, encouraged), how they should be presented } \\
\text { (e.g. aggregated), treatment of bunkers, where feedstocks treated. }\end{array}$ \\
\hline Completeness & $\begin{array}{l}\text { Use of notation keys to report on completeness, transparently show } \\
\text { gaps }\end{array}$ \\
\hline Key categories & $\begin{array}{l}\text { Required to estimate and report, level and trend (cross reference } \\
\text { tables to be used) }\end{array}$ \\
\hline Verification & $\begin{array}{l}\text { Guidance on process to compare estimates for verification; } \\
\text { requirement to provide verification info when using tier } 3 \text { methods }\end{array}$ \\
\hline Uncertainties & $\begin{array}{r}\text { Requirement to report as outlined in section E, specifies table to be } \\
\text { used }\end{array}$ \\
\hline Recalculations & $\begin{array}{l}\text { Requirement to report these in the NIR for all years, guidance on } \\
\text { what to report }\end{array}$ \\
\hline $\mathrm{QA} / \mathrm{QC}$ & Requirement to report on plan and procedures \\
\hline Corrections & $\begin{array}{l}\text { Specifies inventories shall not include corrections, e.g. for climate } \\
\text { variations or electricity trade }\end{array}$ \\
\hline 2. National Inventory Report & $\begin{array}{l}\text { Requirement to submit NIR, specifies years NIR should cover, } \\
\text { electronic submission, and description of its contents. Refers to } \\
\text { detailed outline of NIR in annex I to the Decision. }\end{array}$ \\
\hline 3. Common reporting format tables & $\begin{array}{l}\text { Requires annual electronic submission of tables, generated by CRF Reporter } \\
\text { software. Specifies tables required and recommended, guidance on additional } \\
\text { information and notation keys }\end{array}$ \\
\hline H. Record keeping & $\begin{array}{l}\text { Guidance on gathering and archiving relevant information, in terms of what } \\
\text { information should be kept and why. }\end{array}$ \\
\hline I. Systematic updating of the guidelines & Specifies these shall be reviewed and revised as decided by COP \\
\hline J. Language & $\begin{array}{l}\text { Specifies submissions must be in official UN language, and encourages } \\
\text { submission of English translation }\end{array}$ \\
\hline
\end{tabular}


Table 16. Information to track progress with NDC: outline in APA non-paper compared with BUR and BR outline

\begin{tabular}{|c|c|c|}
\hline \multirow[b]{2}{*}{ APA non-paper annex } & \multicolumn{2}{|c|}{ Current outlines for reporting on biennial basis } \\
\hline & Biennial Report & Biennial Update Report \\
\hline \multirow[t]{2}{*}{ 1. Objectives and Principles } & 1. Objectives & 1. Objectives \\
\hline & & 2. Scope \\
\hline \multicolumn{3}{|l|}{$\begin{array}{l}\text { 2. National circumstances and } \\
\text { institutional arrangements }\end{array}$} \\
\hline $\begin{array}{l}\text { 3. Description of Party's NDC under } \\
\text { Art. } 4 \text {, including updates }\end{array}$ & $\begin{array}{l}\text { 3. Quantified economy-wide reduction } \\
\text { target, including gases and sectors } \\
\text { covered by mitigation target, and GWP } \\
\text { values used (Mandatory) }\end{array}$ & \\
\hline \multicolumn{3}{|l|}{$\begin{array}{l}\text { 4. Progress made in implementing its } \\
\text { NDC under Art } 4 \text { to date }\end{array}$} \\
\hline \multicolumn{3}{|l|}{$\begin{array}{l}\text { a) Indicators to track progress in } \\
\text { implementing its NDC under Art. } 4\end{array}$} \\
\hline $\begin{array}{l}\text { 5. Progress made in achieving its NDC } \\
\text { under Art } 4 \text { for the target year/period }\end{array}$ & $\begin{array}{l}\text { 4. Progress in achievement of quantified } \\
\text { economy-wide emission reduction targets } \\
\text { and relevant information (Mandatory) }\end{array}$ & \\
\hline $\begin{array}{l}\text { a) Indicators to track progress in } \\
\text { achieving its NDC under Art. } 4\end{array}$ & $\begin{array}{l}\text { A. Mitigation actions and their effects } \\
\text { (Mandatory) } \\
\text { B. Estimates of emission reductions and } \\
\text { removals and the use of units from the } \\
\text { market-based mechanisms and land use, } \\
\text { land-use change and forestry activities } \\
\text { (Mandatory) }\end{array}$ & \\
\hline $\begin{array}{l}\text { 6. Mitigation policies and measures, } \\
\text { actions and plans, and other actions } \\
\text { with mitigation co-benefits, related to } \\
\text { the implementation and achievement } \\
\text { of an NDC under Art. } 4 \text {, including } \\
\text { effects (historical and expected), } \\
\text { barriers and costs }\end{array}$ & 4A. Mitigation actions and their effects & $\begin{array}{l}\text { 4. Mitigation actions (Voluntary) (should } \\
\text { provide information on actions to mitigate } \\
\text { climate change) } \\
\text { For mitigation action reported, Parties shall, } \\
\text { to the extent possible communicate } \\
\text { information on coverage, results of actions, } \\
\text { use of units, progress with implementation. }\end{array}$ \\
\hline $\begin{array}{l}\text { 7. Summary of GHG emissions and } \\
\text { removals, as applicable }\end{array}$ & $\begin{array}{l}\text { 2. Information on GHG emissions and } \\
\text { trends (Mandatory for: total emissions; all } \\
\text { gases; all years from } 1990 \text { up to N-2; } \\
\text { metrics, method and format specified; } \\
\text { description of inventory system) }\end{array}$ & $\begin{array}{l}\text { 3. National GHG inventory (Mandatory to } \\
\text { report on certain gases for certain years; } \\
\text { rest voluntary) }\end{array}$ \\
\hline $\begin{array}{l}\text { 8. Projections of GHG emissions and } \\
\text { removals, as applicable }\end{array}$ & $\begin{array}{l}\text { 5. Projections (Mandatory for } 2020 \text { and } \\
\text { 2030, references National } \\
\text { Communication guidelines) }\end{array}$ & \\
\hline $\begin{array}{l}\text { 9. Info on parties' accounting under } \\
\text { Art. } 4.13 \text { and } 4.14\end{array}$ & \multirow{2}{*}{$\begin{array}{l}\text { 4B. Estimates of emission reductions and } \\
\text { removals and the use of units from the } \\
\text { market-based mechanisms and land use, } \\
\text { land-use change and forestry activities }\end{array}$} & \\
\hline 10. Info related to Art. 6, as applicable & & \\
\hline $\begin{array}{l}\text { 11. Other information, where } \\
\text { applicable and appropriate }\end{array}$ & $\begin{array}{l}\text { 7. Other reporting matters (Voluntary, } \\
\text { domestic compliance arrangements, any } \\
\text { other information) }\end{array}$ & \\
\hline 12. Capacity building needs & & $\begin{array}{l}\text { 5. Finance, technology and capacity } \\
\text { building needs (Voluntary) }\end{array}$ \\
\hline \multicolumn{3}{|l|}{ 13. Improvement plan } \\
\hline \multirow[t]{2}{*}{ 14. Reporting format } & 8. Reporting & 6. Submission \\
\hline & 9. Updating of the guidelines & 7. Updating the guidelines \\
\hline
\end{tabular}

Note: Section 6 of the BR guidelines covers financial, technological and capacity-building support provided to developing country Parties; this is not included in the table as it does not correspond to the more specific mitigation-related outline provided in APA (2017). Text in italics lists corresponding section in BR or BUR where the information is provided, but where structure and ordering differ from the non-paper outline.

Source: APA, 2015; Decision 2/CP.17. 
Table 17. Examples of national monitoring arrangements adapted to include climate finance received

\begin{tabular}{|c|c|c|c|c|}
\hline $\begin{array}{c}\text { Source of } \\
\text { country } \\
\text { information }\end{array}$ & Country & Monitoring arrangement of climate finance received & $\begin{array}{l}\text { Entity responsible for } \\
\text { monitoring }\end{array}$ & $\begin{array}{c}\text { Type of finance } \\
\text { (financial instrument } \\
\text { monitored) }\end{array}$ \\
\hline UNDP, 2015 & Nepal & $\begin{array}{l}\text { Nepal's district country public expenditure and institutional } \\
\text { review (dCPEIR) that was commenced in } 2015\end{array}$ & $\begin{array}{l}\text { The governments of five } \\
\text { pilot districts in Nepal }\end{array}$ & $\begin{array}{l}\text { International public } \\
\text { and private finance* } \\
\text { (grants and loans) }\end{array}$ \\
\hline UNDP, 2015 & Bangladesh $^{\star *}$ & $\begin{array}{l}\text { On-budget climate-specific ODA received is tracked using a } \\
\text { system applied to domestic expenditure (Le and Baboyan, } \\
\text { 2015). The data is reported in Climate Protection and } \\
\text { Development: Budget Report 2017-2018 (Government of } \\
\text { Bangladesh, 2017) }\end{array}$ & $\begin{array}{l}\text { Ministry of Planning; } \\
\text { Ministry of Finance (Khan et } \\
\text { al., 2017) }\end{array}$ & $\begin{array}{l}\text { International public } \\
\text { climate finance } \\
\text { (grants and loans) }\end{array}$ \\
\hline UNDP, 2015 & Thailand ${ }^{\star *}$ & $\begin{array}{l}\text { Currently climate finance received is monitored and } \\
\text { analysed when there are reporting obligations but there is a } \\
\text { strong interest in developing a monitoring system of climate } \\
\text { finance received in the context of the Paris Agreement and } \\
\text { the implementation of Thailand's NDC }\end{array}$ & $\begin{array}{l}\text { The Office of National } \\
\text { Resources and } \\
\text { Environmental Policy and } \\
\text { Planning }\end{array}$ & $\begin{array}{l}\text { International public } \\
\text { climate finance (not } \\
\text { identified) }\end{array}$ \\
\hline UNDP, 2015 & Cambodia** & $\begin{array}{l}\text { A monitoring system of climate finance received has been } \\
\text { developed using a marking system with the support of } \\
\text { UNDP. The data is published using an online portal } \\
\text { (www.odacambodia.com) and located under the category of } \\
\text { services and cross sectoral programmes. The data has } \\
\text { been reported since } 2016 \text { as part of the Climate Public } \\
\text { Expenditure Review }\end{array}$ & $\begin{array}{l}\text { The Ministry of Economy } \\
\text { and Finance }\end{array}$ & $\begin{array}{l}\text { International public } \\
\text { climate finance (not } \\
\text { identified) }\end{array}$ \\
\hline UNDP, 2015 & $\begin{array}{l}\text { The } \\
\text { Philippines }\end{array}$ & $\begin{array}{l}\text { Climate finance monitoring system using broad policy } \\
\text { parameters (ADB, 2015; Tirpak et al., 2014) }\end{array}$ & $\begin{array}{l}\text { Department of Finance, } \\
\text { Department of Budget and } \\
\text { Management, Climate } \\
\text { Change Commission, } \\
\text { NEDA, Department of } \\
\text { Interior and Local } \\
\text { Government }\end{array}$ & $\begin{array}{l}\text { International public } \\
\text { and private finance }\end{array}$ \\
\hline ODI, 2013 & Tanzania & $\begin{array}{l}\text { Climate finance data is monitored and analysed when there } \\
\text { are reporting obligations }\end{array}$ & $\begin{array}{l}\text { Ministry of Finance and } \\
\text { Economic Development } \\
\text { (MoFED) }\end{array}$ & $\begin{array}{l}\text { International public } \\
\text { finance/on-budget } \\
\text { ODA (not identified) }\end{array}$ \\
\hline ODI, 2013 & Uganda & $\begin{array}{l}\text { Integrated Financial Management System (IFMS) gives } \\
\text { complete coverage of central government departments' } \\
\text { transactions but does not specifically address climate } \\
\text { change }\end{array}$ & $\begin{array}{l}\text { The Ministry of Finance } \\
\text { (MoFPED) }\end{array}$ & $\begin{array}{l}\text { International public } \\
\text { finance/on-budget } \\
\text { ODA (not identified) }\end{array}$ \\
\hline UNDP, 2015 & Zambia & $\begin{array}{l}\text { Zambia Development and Assistance Database (ZDAD) } \\
\text { records international climate finance received. Private } \\
\text { climate finance inflows are partially captured by the Zambia } \\
\text { Development Agency (ZDA) (Mulenga, 2013) }\end{array}$ & $\begin{array}{l}\text { ZDAD, managed by the } \\
\text { Ministry of Finance; ZDA is } \\
\text { part of the Ministry of Trade, } \\
\text { Commerce and Industry }\end{array}$ & $\begin{array}{l}\text { International public } \\
\text { and private finance } \\
\text { (not identified) }\end{array}$ \\
\hline UNDP, 2015 & Viet Nam & $\begin{array}{l}\text { Climate finance received is monitored as part of the NAP } \\
\text { process and NDC implementation strategy using a key word } \\
\text { filtering system. The country is pursuing regulatory and } \\
\text { budget guideline revisions to integrate disaster risk } \\
\text { reduction, green growth and climate change adaptation into } \\
\text { the design of public investments and sub-national budgeting }\end{array}$ & $\begin{array}{l}\text { The Ministry of Planning and } \\
\text { Investment (MPI) }\end{array}$ & $\begin{array}{l}\text { International public } \\
\text { climate finance (not } \\
\text { identified) }\end{array}$ \\
\hline $\begin{array}{l}\text { Desk-based } \\
\text { research }\end{array}$ & Indonesia & $\begin{array}{l}\text { Climate mitigation expenditure including climate finance } \\
\text { received is monitored using a tagging system based on } \\
\text { Indonesia's National Action Plan for Reducing Greenhouse } \\
\text { Gas Emissions }\end{array}$ & The Ministry of Finance & $\begin{array}{l}\text { International public } \\
\text { climate finance (not } \\
\text { identified) }\end{array}$ \\
\hline
\end{tabular}




\begin{tabular}{l|l|l|l|l}
\hline $\begin{array}{c}\text { Source of } \\
\text { country } \\
\text { information }\end{array}$ & Country & Monitoring arrangement of climate finance received & $\begin{array}{c}\text { Entity responsible for } \\
\text { monitoring }\end{array}$ & $\begin{array}{l}\text { Type of finance } \\
\text { (financial instrument } \\
\text { monitored) }\end{array}$ \\
\hline $\begin{array}{l}\text { Desk-based } \\
\text { research }\end{array}$ & Chile & $\begin{array}{l}\text { Climate finance is monitored using a manual data gathering } \\
\text { system. Focal points in relevant government agencies } \\
\text { submit the data using a standard form when there are } \\
\text { reporting obligations, such as under the UNFCCC. This } \\
\text { process is in practice since 2014 when Chile submitted its } \\
\text { first BUR. }\end{array}$ & $\begin{array}{l}\text { Department of Finance and } \\
\text { International Negotiation for } \\
\text { Climate, Ministry of } \\
\text { Environment }\end{array}$ & $\begin{array}{l}\text { International public } \\
\text { and private } \\
\text { finance(grants and }\end{array}$ \\
loans) \\
$\begin{array}{l}\text { Desk-based } \\
\text { research }\end{array}$ & Brazil & $\begin{array}{l}\text { Brilian Development Bank (BNDES) monitoring system of } \\
\text { climate finance received by the Amazon Fund. However, it } \\
\text { does not cover all climate finance support received by } \\
\text { Brazil (Marchesini, 2015; Vivideconomics, 2012) }\end{array}$ & $\begin{array}{l}\text { Brazilian Development Bank } \\
\text { (BNDES) }\end{array}$ & $\begin{array}{l}\text { International public } \\
\text { and private finance } \\
\text { (Grants and result } \\
\text { based payments) }\end{array}$ \\
\hline
\end{tabular}

Note: Countries are listed not based on specific order. The following countries participate in CPEIR but are not included in the table due to lack of information: Samoa, Nauru, Namibia, Vanuatu, Marshall Islands, Kiribati, and Morocco. *Insufficient information given to determine whether private finance amounts are mobilised by public climate finance interventions. ** Supported by a UNDP programme, "Strengthening the Governance of Climate Change Finance to benefit the poor and vulnerable”.

Source: Asante et al., 2015; Bird et al., 2013, 2016; Government of Cambodia, 2016; Ponlok et al., 2014; Sethea, n.d.; UNDP-CDDE-ODI, 2013; UNDP, 2013, 2015; van Rooij, Brown, Nakhooda, and Watson, 2013b, 2013a. 


\section{References}

Abeille, V. et al. (2015), Estimating private climate finance mobilised by France's climate finance

[34] interventions, Climate \& Energy Solutions, https://www.oecd.org/env/researchcollaborative/Final\%20reportV5\%20Artelia\%20Trinomics.pdf.

ADB, Asian Development Bank; AfDB, African Development Bank; EIB, European Investment Bank; EBRD, European Bank for Reconstruction and Development; IDB, Inter-American Development Bank; WB, World Bank (2016), 2015 Joint Report On Multilateral Development Banks' Climate Finance, http://www.adb.org/documents/joint-report-mdbs-climate-finance2015.

Allen, D. (2014), "Review Methane emissions from natural gas production and use: reconciling bottom-up and top-down measurements", Current Opinion in Chemical Engineering, Vol. 5, pp. 78-83, http://dx.doi.org/10.1016/j.coche.2014.05.004.

APA (2017), Agenda item 5 - Modalities, procedures and guidelines for the transparency framework for action and support referred to in Article 13 of the Paris Agreement - Informal Note by the Co-Facilitators - final version, UNFCCC Secretariat, Bonn, http://unfccc.int/files/meetings/bonn_may_2017/insession/application/pdf/apa2017_i5_informal_note_by_the_co-facilitators_.pdf (accessed on 25 October 2017).

Bappenas (2013), Indonesia's Framework for Nationally Appropriate Mitigation Actions, Ministry for National Development Planning Republic of Indonesia (Bappenas), Jakarta, Indonesia, http://ranradgrk.bappenas.go.id/rangrk/admincms/downloads/publications/Indonesias framewor k_for_Nationally_Appropriate_Mitigation_Actions.pdf.

Bird, N. and I. Granoff (2016), National monitoring approaches for climate change public finance, GIZ, Eschborn, Germany, https://www.odi.org/sites/odi.org.uk/files/resourcedocuments/10663.pdf (accessed on 22 September 2017).

Bo, C. and W. Yao((n.d.)), “China's Low Carbon Finance and Investment Pathway Annex B: China's Climate Finance and Investment Gap”, https://www.e3g.org/docs/Annex_B_China\%E2\%80\%99s_Climate_Finance_and_Investment_G ap.pdf (accessed on 27 October 2017).

Borgogno, D. (2016), GSP survey on capacity building needs.

Boyd, A. et al. (2014), “Current approaches to MRV in South Africa: a scoping study”, Climate Policy, Vol. 14/3, pp. 397-416, http://dx.doi.org/10.1080/14693062.2014.845477.

Brazil, Argentina and Uruguay (2017), Views of Brazil, Argentina and Uruguay on APA Agenda Item 5: 'Modalities, procedures and guidelines (MPG) for the transparency framework for action and support referred to in Article 13 of the Paris Agreement', UNFCCC Secretariat, Bonn, http://www4.unfccc.int/Submissions/Lists/OSPSubmissionUpload/525 $323 \quad 1313246482555219$ 82-Bra\%20Arg\%20Uy\%20-\%20SubmissionArt13\%20Transparency\%20Framework\%20FINAL.pdf (accessed on 24 October 2017).

Briner, G. and S. Moarif (2016), Enhancing transparency of climate change mitigation under the 
Paris Agreement: lessons from experience, OECD Publishing, http://dx.doi.org/10.1787/a634dc1f-en.

Briner, G. and S. Moarif (2016), Unpacking Provisions Related to to Transparency of Mitigation and Support in the Paris Agreement, CCXG, http://www.oecd.org/environment/cc/Unpackingtransparency-provisions-Paris-Agreement-CCXG-May2016.pdf.

Brown, J. and D. Wang (2015), Estimating Mobilized Private Finance for Adaptation: Exploring Data and Methods, Climate Policy Initiative Report in collaboration with the OECD, http://climatepolicyinitiative.org/publication/estimating-mobilized-private-finance-foradaptation-exploring-data-and-methods.

Buchner, B. et al. (2012), "Public Climate Finance: A Survey of Systems to Monitor and Evaluate Climate Finance Effectiveness CPI Report Climate Policy Initiative", https://climatepolicyinitiative.org/wp-content/uploads/2012/07/Public-Climate-FinanceSurvey.pdf (accessed on 27 October 2017).

Buchner, B. et al. (2014), The Global Landscape of Climate Finance 2014, http://climatepolicyinitiative.org/publicati on/global-landscape-of-climatefinance-2014/.

Carman, R. (2014), “Strengthening National Greenhouse Gas (GHG) Inventory Systems”, Low Emission Capacity Building Programme, UNDP, New York, http://www.lowemissiondevelopment.org/lecbp/docs/LECB_Information_Brief_Strengthening GHG r2.pdf (accessed on 24 October 2017).

Caruso, J. and J. Ellis (2013), "Comparing Definitions and Methods to Estimate Mobilised Climate Finance", OECD Publishing, http://dx.doi.org/10.1787/5k44wj0s6fq2-en.

CDKN (2012), OPINION: The role of transparency in managing climate finance, https://cdkn.org/2012/11/opinion-the-role-of-transparency-in-managing-climatefinance/?loclang=en_gb (accessed on 02 October 2017).

Cheah, S. (2016), Accounting for emissions intensity target, OECD, Paris, https://www.slideshare.net/OECD_ENV/accounting-for-emissions-intensity-target-sin-liangcheah-ccxg-gf-september-2016-breakout-2 (accessed on 25 October 2017).

CIF (2014), Impact Evaluation: Approaches to Evidence-based Learning throughout the CIF Project Cycle, https://www.climateinvestmentfunds.org/sites/default/files/knowledgedocuments/impact_evaluation_0.pdf.

Dagnet, Y. et al. (2017), "Mapping the linkages between the transparency framework and other provisions of the Paris Agreement", Project for Advancing Climate Transparency (PACT), World Resources Institute, Washington D.C., http://www.wri.org/publication/pact-linkagestransparency-framework/. (accessed on 24 October 2017).

Damassa, T. (2013), “Tracking Greenhouse Gases: 3 Factors for Successful National Inventories”, WRI Blog, Measurement and Performance Tracking Initiative (MAPT),, World Resources Institute, Washington D.C., http://www.wri.org/blog/2013/04/tracking-greenhouse-gases-3factors-successful-national-inventories (accessed on 24 October 2017).

DNPI (2010), Indonesia's greenhouse gas abatement cost curve, Dewan Nasional Perubahan Iklim, Jakarta, Indonesia, https://issuu.com/thamrinschool/docs/updating indonesia s greehouse gas.

ECN (2010), Policy Brief: Marginal Abatement Cost (MAC) Curve, ECN, http://dx.doi.org/10.4210/ssee.pbs.2009.0001.

Ellis, J. and S. Moarif (2015), "Identifying and addressing gaps in the UNFCCC reporting 
framework”, OECD/IEA Climate Change Expert Group Papers, No. 2015/7, OECD

Publishing, Paris, http://dx.doi.org/10.1787/5jm56w6f918n-en.

Ellis, J. and S. Moarif (2016), Enhancing transparency of climate finance under the Paris Agreement: lessons from experience, http://www.oecd.org/environment/cc/Enhancingtransparency-of-climate-finance.pdf.

EPA (2017), Climate change data hub: GCF project pipeline, http://climatedatahubgh.com/gh/pages-2-3-2/ (accessed on 05 July 2017).

EU (2014), Submission by Greece and the European Commission on behalf of the European Union and its Member States. Subject: EU Submission on Mitigation in the 2015 Agreement, EU, Athens, http://unfccc.int/files/bodies/awg/application/pdf/el-05-28-adp ws1 submission.pdf.

García, J. (2016), Renewable Energy Financing: the case of Chile, https://www.oecd.org/env/researchcollaborative/RE_finance_Chile_formatted.pdf.

GCF (2017), Implementation of the initial Strategic Plan of the GCF - Addendum I : Update on country programmes and entity work programmes, GCF, Songdo, Republic of Korea, https://www.greenclimate.fund/documents/20182/584114/GCF_B.16_04_Add.01_Implementation of the initial Strategic Plan of the GCF Addendum I Update on cou ntry programmes and entity work programmes.pdf/526a4757-1d77-4394-9f1e-c8ec6165a514.

Goldstein, M.((n.d.)), The program costs of impact evaluation | Impact Evaluations, http://blogs.worldbank.org/impactevaluations/program-costs-impact-evaluation (accessed on 30 October 2017).

Government of India (2007), “Climate Change and India: a 4 x4 Assessment”, Vol. 1, http://www.moef.nic.in/downloads/public-information/fin-rpt-incca.pdf (accessed on 27 October 2017).

Government of Indonesia (2015), “First Biennial Update Report”.

Government of Indonesia (2017), Indonesia's National Registry System on Climate Change, http://ditjenppi.menlhk.go.id/srn/ (accessed on 10 July 2017).

Government of Nepal (2012), “Climate Change Budget Code: Documenting the national process of arriving at multi-sectoral consensus”, http://www.npc.gov.np/images/category/Climate-changebudget-code.pdf (accessed on 27 October 2017).

Government of South Africa (2014), South Africa's First Biennial Update Report, http://unfccc.int/resource/docs/natc/zafbur1.pdf.

Government of South Africa (2015), The National Climate Change Response Monitoring and Evaluation System Framework, https://www.environment.gov.za/sites/default/files/reports/nationalclimatechangeresponse_MES F.pdf.

Government of the Republic of Macedonia (2014), First Biennial Update Report on Climate Change, http://unfccc.int/resource/docs/natc/macbur1eng.pdf.

Government of the Socialist Republic of Viet Nam (2014), The initial biennial updated report of Viet Nam to the United Nations Framework Convention on Climate Change, http://unfccc.int/resource/docs/natc/vnmbur1.pdf.

Green, A. and M. Westphal (2017), Designing and Testing a Methodology to Understand Private Climate Finance Mobilization from Policy and Other Causal Factors. 
Haščič, I. et al. (2015), Public Interventions and Private Climate Finance Flows: Empirical Evidence from Renewable Energy Financing, OECD Publishing, http://dx.doi.org/10.1787/5js6b1r9lfd4-en.

Henzler, M.((n.d.)), Climate Finance in Asia, Adelphi, Berlin, http://www.switchasia.eu/fileadmin/user_upload/Henzler.pdf.

Herold, M. et al. (2012), “A stepwise framework for developing REDD+ reference levels”, in Analyzing REDD+, Center for International Forestry Research (CIFOR), Bogor, Indonesia, http://www.cifor.org/publications/pdf_files/Books/BAngelsen120116.pdf.

ICAI (2011), “The Department for International Development's Climate Change Programme in Bangladesh”, https://www.oecd.org/countries/bangladesh/49092047.pdf (accessed on 30 October 2017).

Jachnik, R., R. Caruso and A. Srivastava (2015), Estimating Mobilised Private Climate Finance: Methodological Approaches, Options and Trade-offs", OECD Environment Working Papers, OECD Publishing, http://dx.doi.org/10.1787/5js4x001rqf8-en.

Keller, C. et al. (2011), Evidence for under-reported western European emissions of the potent greenhouse gas HFC-23, American Geophysical Union Publications, Washington, D.C., http://dx.doi.org/10.1029/2011GL047976.

Kempa, K. and U. Moslener (2016), Options for Estimating Mobilised Private Climate Finance, http://fs-unep-centre.org/publications/options-estimating-mobilised-private-climate-finance.

Levin, I. et al. (2010), The global SF6 source inferred from long-term high precision atmospheric measurements and its comparison with emission inventories, European Geosciences Union, Copernicus Publications, http://www.atmos-chem-phys.net/10/2655/2010/ (accessed on 24 October 2017).

Levin, K. (2016), Guidance for accounting: emissions intensity goals, and goals relative to BAU emissions levels under Article 4, OECD, Paris, https://www.slideshare.net/OECD_ENV/guidance-for-accounting-emissions-intensity-goalsand-goals-relative-to-bau-emissions-levels-under-article-4-kelly-levin-ccxg-gf-september-2016breakout-2 (accessed on 25 October 2017).

Mahadevan, B. (2015), “An integrated MRV system in South Africa”, http://www.mitigationpartnership.net/gpa (accessed on 27 October 2017).

Mazza, F. et al. (2016), UNFCCC Standing Committee on Finance 2016 Biennial Assessment and Overview of Climate Finance Flows Report, http://unfccc.int/6877.

McNicoll, L. et al. (2017), Estimating publicly-mobilised private finance for climate action: A South African Case Study, OECD Publishing, http://dx.doi.org/10.1787/a606277c-en.

Moncel, R. and K. Stasio (2011), Transparency of Climate Finance: Results from Cancun and Next Steps, WRI website, http://www.wri.org/blog/2011/04/transparency-climate-finance-resultscancun-and-next-steps (accessed on 02 October 2017).

Mostert, W., H. Bolscher and E. Veenstra (2015), Pilot study of private finance mobilised by Denmark for climate action in developing countries, Trinomics, https://www.oecd.org/env/researchcollaborative/DK\%20final\%20private\%20finance\%20mobilis d.pdf.

OECD (2015), Climate Finance in 2013-14 and the USD 100 billion goal, http://www.oecd.org/fr/env/cc/oecd-cpi-climate-finance-report.htm. 
OECD (2017), Secretariat's proposal to adjust information currently reported by DAC members on [28] environment-related development finance, DCD/DAC/STAT(2017)7/REV1.

Prag, A., C. Hood and P. Barata (2013), "Made to Measure: Options for Emissions Accounting under the UNFCCC”, http://www.oecd.org/env/cc/ccxg.htm.

Prasad, S., K. Ganesan and V. Gupta (2017), "Enhanced Transparency Framework in the Paris Agreement”, CEEW Working Paper , Council on Energy, Environment and Water, http://ceew.in/pdf/CEEW\%20\%20Enhanced\%20Transparency\%20Framework\%20in\%20the\%20Paris\%20Agreement\%2012 May17.pdf (accessed on 25 October 2017).

Schoenefeld, J., M. Hildén and A. Jordan (2016), “The Challenges of Monitoring National Climate Policy: Learning Lessons from the EU”, Climate Policy, pp. Taylor \& Francis, London, http://dx.doi.org/10.1080/14693062.2016.1248887.

Sekulić, G. et al. (2013), Climate Vulnerability Assessment: Serbia, http://dx.doi.org/10.1016/B978- [59] 0-12-384703-4.00512-8.

Stadelmann, M., A. Michaelowa and J. Roberts (2013), "Difficulties in accounting for private finance in international climate policy”, Climate Policy, Vol. 13/6, pp. 718-737, http://dx.doi.org/10.1080/14693062.2013.791146.

Tirpak, D., K. Stasio and L. Tawney (2012), "Monitoring the receipt of international climate finance by developing countries”, World Resource Institute, Washington, DC.

Tirpak, D., L. Brown and A. Ronquillo-Ballesteros (2014), "Monitoring Climate Finance in Developing Countries : Challenges and Next Steps", WRI, Washington, DC, https://www.wri.org/sites/default/files/wri13_monitoringclimate_final_web.pdf.

Torvanger, A., P. Narbel and H. Francke Lund (2015), Estimating mobilized private climate finance for developing countries - a Norwegian study, CICERO Center for International Climate and Environmental Research, http://www.cicero.uio.no/en/posts/news/putting-numbers-onnorwegian-climate-finance-flows.

UNDP (2015), Budgeting for climate change: how governments have used national budgets to articulate a response to climate change, UNDP, Bangkok, Thailand, https://www.climatefinancedevelopmenteffectiveness.org/sites/default/files/documents/27_08_15/1 Budgeting for Climate Change August 2015.pdf.

UNDP (2017), Tracking private climate finance in five (test) countries: Chile, Ecuador, Thailand, Vietnam and Indonesia.

UNFCCC Standing Committee on Finance (2016), 2016 Biennial Assessment and Overviewof Climate Finance Flows Report, http://unfccc.int/files/cooperation_and_support/financial_mechanism/standing_committee/applic ation/pdf/2016_ba_technical_report.pdf.

UNFCCC (2000), Annex II- Guidelines for the preparation of national communications by Parties included in Annex I to the Convention, Part II: UNFCCC reporting guidelines on national communications, FCCC/CP/1999/7, http://unfccc.int/resource/docs/cop5/07.pdf.

UNFCCC (2011), Annex I- UNFCCC biennial reporting guidelines for developed country Parties, FCCC/CP/2011/9/Add.1, https://unfccc.int/resource/docs/2011/cop17/eng/09a01.pdf.

UNFCCC (2013), Common tabular format for "UNFCCC biennial reporting guidelines for 
developed country Parties”, FCCC/CP/2012/8/Add.3,

http://unfccc.int/resource/docs/2012/cop18/eng/08a03.pdf.

UNFCCC (2015), Decision 9/CP.21, Methodologies for the reporting of financial information by

Parties included in Annex I to the Convention, FCCC/CP/2015/10/Add.2,

http://unfccc.int/resource/docs/2015/cop21/eng/10a02.pdf.

UNFCCC (2015), 18 Industrialized Countries Issue Statement on Climate Finance, http://newsroom.unfccc.int/financial-flows/18-industrial-states-release-climate-financestatement/.

UNFCCC (2015), Background paper prepared for the 2015 SCF forum: Coherence and coordination issues related to finance for forests, taking into account different policy approaches, UNFCCC, Bonn, Germany, https://unfccc.int/files/cooperation_and_support/financial_mechanism/standing_committee/appli cation/pdf/background_paper_prepared_for_the_2015_scf_forum.pdf.

UNFCCC (2015), "Synthesis report on the aggregate effect of the intended nationally determined contributions", No. FCCC/CP/2015/7, UNFCCC Secretariat, Bonn, http://unfccc.int/resource/docs/2015/cop21/eng/07.pdf (accessed on 25 October 2017).

UNFCCC (2016), Development of modalities for the accounting of financial resources provided and mobilized through public interventions in accordance with Article 9, paragraph 7, of the Paris Agreement. Submissions from Parties and observer organizations., FCCC/SBSTA/2016/MISC.3, http://unfccc.int/resource/docs/2016/sbsta/eng/misc03.pdf.

UNFCCC (2016), UNFCCC Standing Committee on Finance: 2016 Biennial Assessment and Overview of Climate Finance Flows Report, UNFCCC, Bonn, Germany, http://unfccc.int/files/cooperation_and_support/financial_mechanism/standing_committee/applic ation/pdf/2016_ba_technical_report.pdf.

UNFCCC (2016), “Compilation and Synthesis of Second Biennial Reports, Report by the Secretariat: Addendum”, FCCC/SBI/2016/INF.10/Add.1, UNFCCC Secretariat, Bonn, http://unfccc.int/resource/docs/2016/sbi/eng/inf10a01.pdf (accessed on 25 October 2017).

UNFCCC (2017), Modalities for the accounting of financial resources provided and mobilized through public interventions in accordance with Article 9, paragraph 7, of the Paris AgreementTechnical paper by the Secretariat.

UNFCCC (2017), Review Practice Guidance: 2017 Update of the Analysis of the Assessment of Completeness and Transparency of Information Reported in Biennial Reports, UNFCCC Secretariat, Bonn, http://unfccc.int/files/national reports/annex i parties/application/pdf/backgroundpaperanalysis mostlypartially published.pdf (accessed on 25 October 2017).

Van der Laan, J. et al. (2015), Promoting private sector actions in the fight against climate change in Belgium and abroad, Trinomics, http://www.climat.be/files/4314/5873/7318/private_climate_finance_report.pdf.

Vandeweerd, V., Y. Glemarec and S. Billett (2012), Readiness for Climate Finance, UNDP, http://www.undp.org/content/dam/undp/library/Environment and Energy/Climate Strategies/Readiness for Climate Finance 12April2012.pdf.

Weiss, R. and R. Prinn (2011), "Quantifying greenhouse-gas emissions from atmospheric measurements: a critical reality check for climate legislation.”, Philosophical transactions. Series A, Mathematical, physical, and engineering sciences, Vol. 369/1943, pp. 1925-42, 
http://dx.doi.org/10.1098/rsta.2011.0006.

Wen, Z. and P. Xun (2016), "Study on the demand of climate finance for developing countries [60] based on submitted INDC”, http://dx.doi.org/10.1016/j.accre.2016.05.002.

White, H. (2009), "Theory-Based Impact Evaluation: Principles and Practice”, http://www.3ieimpact.org/media/filer_public/2012/05/07/Working_Paper_3.pdf (accessed on 30 October 2017).

World Bank (2014), “Climate Change Public Expenditure and Institutional Review Sourcebook”, http://www.greengrowthknowledge.org/sites/default/files/downloads/resource/World Bank CC PEIR_Sourcebook_0.pdf (accessed on 31 October 2017).

World Bank (2017), Mobilization of private finance by multilateral development banks : 2016 joint report, http://documents.worldbank.org/curated/en/860721492635844277/Mobilization-ofprivate-finance-by-multilateral-development-banks-2016-joint-report.

World Bank (2017), Joint MDB reporting on private investment mobilization: methodology reference guide, http://documents.worldbank.org/curated/en/495061492543870701/Joint-MDBreporting-on-private-investment-mobilization-methodology-reference-guide.

WRI (2014), Mitigation Goal Standard: An accounting and reporting standard for national and subnational greenhouse gas reduction goals, World Resources Institute, Washington D.C., http://www.ghgprotocol.org/mitigation-goal-standard. 


\title{
www.oecd.org/environment/cc/ccxg.htm
}

\author{
www.iea.org
}



With the financial assistance of the European Union 